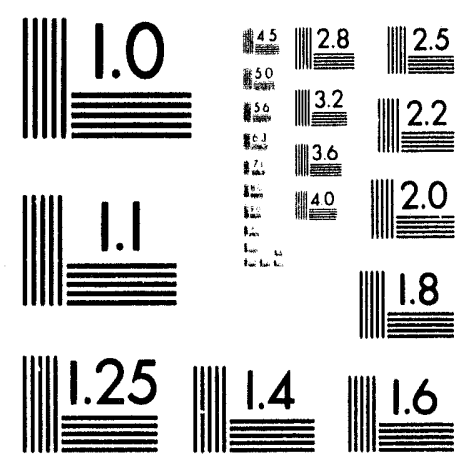



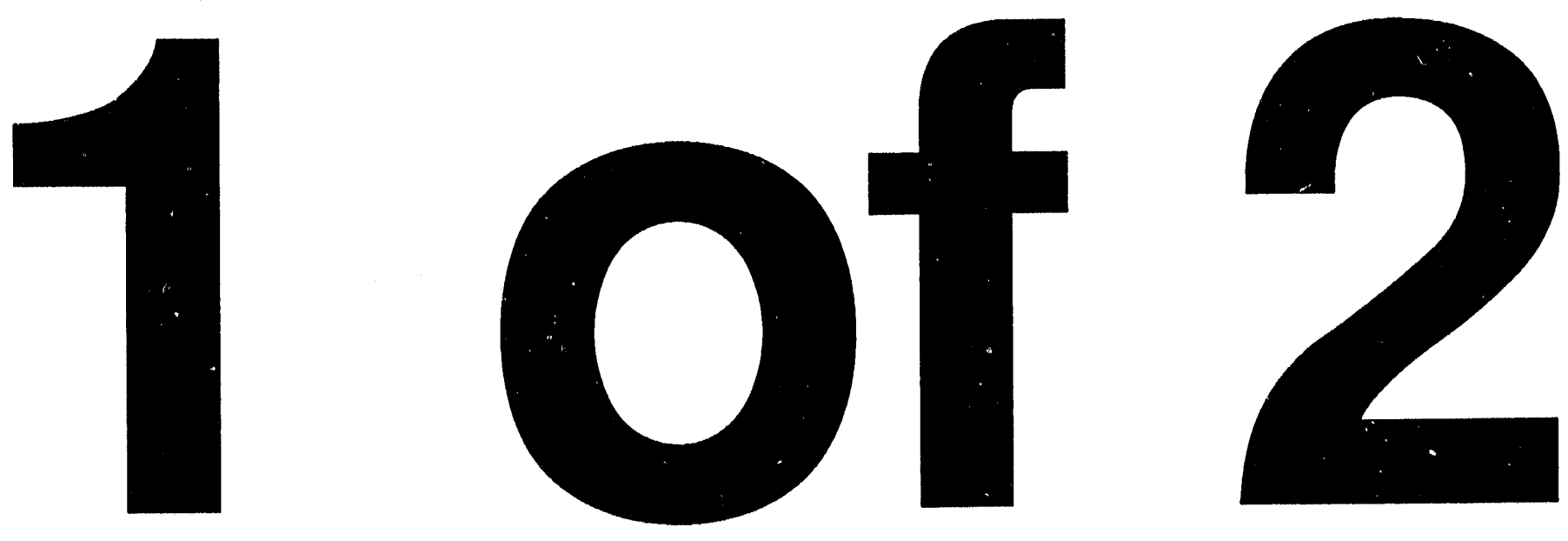


\title{
PHYSICAL AND CHEMICAL CHARACTERISTICS OF FLUORINEL/SODIUM CALCINE GENERATED DURING 30 CM PILOT-PLANT RUN 17
}

\author{
K.N. Brewer \\ G.F. Kessinger \\ LL Litteton \\ A.L Otson
}

July 1993

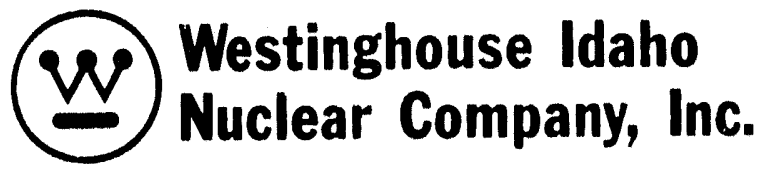

PREPARED FOR THE

DEPARTMENT OF ENERGY

IDAHO OPERATIONS OFFICE

UNDER CONTRACT DE-AC,07-84ID12435

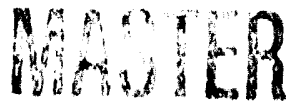




\section{Acknowledgements}

The authors wish to acknowledge: Feddy Dickerson, who performed the XRD analysis; Jeff Laug, who performed the ICP analysis; Del Miley, who performed the SEM analysis; Mike Hankin, who performed the XPS analysis; and Patty Tullock; who put the document in final form. The discussions with B. J. Newby were especially helpful and it was his earlier work that inspired this activity.

This work was funded (K.N.B. and G.F.K.) by the WINCO Laboratory Directed Research and Development program. 


\section{Bummary}

The 30 centimeter (cm) pilot plant calciner Run 17, of March 9, 1987, was performed to study the calcination of fluorinel-sodium blended waste blended at the ratio $3.5: 1$ fluorinel to sodium, respectively. The product of the run was analyzed by a variety of analytical techniques that included $x$-ray powder diffraction (XRD), inductively coupled plasma spectroscopy (ICP), scanning electron microscopy (SEM), and X-ray photoelectron spectroscopy (XPS) to deduce physical and chemical characteristics.

The analytical data, as well as data analyses and conclusions drawn from the data, are presented. 
Table of contents

Acknowledgements . . . . . . . . . . . . . . . . . . . . i

summary . . . . . . . . . . . . . . . . . . . . . . . $1 i$

Table of contents . . . . . . . . . . . . . . . . . . . . . ii

Table of Tables . . . . . . . . . . . . . . . . . . . . v

Table of Figures . . . . . . . . . . . . . . . . . . . . . vi

Introduction . . . . . . . . . . . . . . . . . . . . . 1

Background . . . . . . . . . . . . . . . . . . . . . . . . . 3

Experimental Equipment and Techniques . . . . . . . . . . . . 7

X-Ray Powder Diffraction . . . . . . . . . . . . . 7

Inductively Coupled Plasma Emission spectroscopy, ICP . 8

scanning Electron Microscope spectroscopy, 8EM . . . . . 9

X-Ray Physical Electron spectroscopY, XPB . . . . . . . 10

Analytical Methods Used to Determine Non-Metal

Concentrations . . . . . . . . . . . . . 11

Chloride . . . . . . . . . . . . . . . 11

Fluoride . . . . . . . . . . . . . . . . . 11

Nitrate . . . . . . . . . . . . . . . 12

sulfur . . . . . . . . . . . . . . . 13

Results and Discussion . . . . . . . . . . . . . . . . . . 14

ICP and Non-Metal Determinations . . . . . . . . . . . 14

X-Ray Powder Diffraction Results . . . . . . . . . . 16

BEM Results . . . . . . . . . . . . . . . . . . 19

XPB Data . . . . . . . . . . . . . . . . . . 43

$F \star A \star C \star T$ Program Data . . . . . . . . . . . . . . . 48 
Conclusions . . . . . . . . . . . . . . . . . . . . 52

Appendix A: Point by Point SEM Data for Particle 1 . • • • . 54

Appendix B: Point by Point SEM Data For Particle 2 . • • . 60

Appendix C: Point by Point SEM Data For Particle 3 . • . . . 65

Appendix D: General Composition SEM Data For Small

Particles . . . . . . . . . . . . . . . 69

Appendix E: General Composition SEM Data For Medium

Particles . . . . . . . . . . . . . . . 76

Appendix F: General Composition SEM Data For Large

particles . . . . . . . . . . . . . . . . 82

Appendix G: XPS Raw Data . . . . . . . . . . . . . . . 87

Appendix H: F*A*C*T EQUILIB Results . . . . . . . . . . . . 129

References . . . . . . . . . . . . . . . . . . . . 142 


\section{Table of Tables}

Table I: Simulated Fluorinel Waste, Sodium Waste, and Blend Compositions . . . . . . . . . . . . . . . . . . 5

Table II: Element Concentrations in Run 17 Calcine . . . . 15

Table III: SEM Data: Elemental Weight Percents for Particle

1 From Point Analysis . . . . . . . . . . . . 23

Table IV: SEM Data: Weight Percent Elements in Particle 2

From Point Analysis . . . . . . . . . . . . . . 27

Table V: SEM Data: Weight Percent Elements in Particle 3

From Point Analysis . . . . . . . . . . . . . . 31

Table VI: SEM Data: Weight Percent Elements in Small

Particle Size . . . . . . . . . . . . . . . . 34

Table VII: SEM Data: Weight Percent Elements in Medium

Particle size . . . . . . . . . . . . . . 35

Table VIII: SEM Data: Weight Percent Elements in Large

Particle size . . . . . . . . . . . . . . 36

Tabla Ix: Atomic Concentrations of Elements Found in

Calcine . . . . . . . . . . . . . . . . . . . 45

Tabje X: Compounds Found By XPS Analysis That Are Most

Likely To Be In Run 17 Calcine . . . . . . . . . . 47

Table XI: Products Resulting From F*A*C*T Program . . . . . . 49 
Figure 1: XRD Diffractogram for Run 17 Calcine . . . . . . . 18 Figure 2: Particles Chosen for Point by Point Analysis . . . 20 Figure 3: Particle 1: Locations of Point Analyses . . . . . . 22 Figure 4: Particle 2: Locations of Point Analyses . . . . . . 26 Figure 5: Particle 3: Locations of Point Analyses . . . . . . 30 Figure 6: Particles chosen for General Composition

Determinations . . . . . . . . . . . . . . . 33

Figure 7: X-Ray Mapping of Particle 1 . . . . . . . . . . 38

Figure 8: X-Ray Mapping of Particle 1 . . . . . . . . . . . 39

Figure 9: X-Ray Mapping of Particle 2 . . . . . . . . . . 40

Figure 10: X-Ray Mapping of Particle 2 . . . . . . . . . . . 41

Figure 11: X-Ray Mapping of Particle 3 . . . . . . . . . . . 42

Figure 12: ESCA Scan . . . . . . . . . . . . . . . . . . 44 


\section{Introduotion}

Most of the calcines generated in the Idaho Chemical processing Plant (ICPP) pilot plants and the full-scale facility have never been thoroughly characterized. As a result, the distribution of crystalline and amorphous phases, and the chemical compositions of these phases in the calcine particles, are unknown. During many discussions of calcination, it has been generally assumed that all the non-volatile components of the aqueous calcine feed formed oxides in the solid calcine. It was important to test the reasonability of this assumption because the phase distribution and chemical composition of calcine is important input information for the design of future ICPP processes for calcine immobilization, and for the development of future calcination flowsheets.

Future processes necessary for calcine immoblilization includes calcine grinding and transport. The distribution of compounds in the calcine must be known in order to determine calcine homogeneity. The homogeneity of calcine will influence grinding parameters; the less homogenous the calcine, the smaller it must be ground for the immobilization process. Particle size is important because it will impact the development of the processing equipment required for calcine immobilization. 
Knowledge about the phase behavior of calcine is beneficial input data for waste form development and for deduction of the chemistry of the calcination process. Knowing the chemical forms of each species in the calcine could contribute to waste forms development, particularly to the understanding of the chemical reactions taking place during the formation of glass and glassceramic materials from admixtures of calcine and glass-forming materials. A knowledge of the chemistry that is occurring in the calcination process could also lead to the development of new calcination flowsheets needed for faster depletion of the sodium waste inventory and new calcination flowsheets that could result in greater waste volume reductions when the liquid waste is converted to the solid calcined product. 


\section{Background}

High level radioactive liquid wastes (HLW) of various chemical compositions have been produced at the ICPP during the reprocessing of spent reactor fuels. The composition of the liquid waste is dependent on the fuel type. The classifications of liquid wastes, and the associated calcined products, include: aluminum HLW, which is calcined to produce alumina calcine; stainless steel HLW, which is calcined to produce stainless steel calcine; zirconium HLW, which is calcined to produce zirconia calcine or is blended with sodium waste and calcined to produce zirconia-sodium calcine; and fluorinel HLW, which calcined to produce fluorinel calcine or is blended with sodium waste and calcined to produce fluorinel-sodium calcine. These HLW solutions are the aqueous raffinates that were generated during the uranium recovery from the highly radioactive dissolver product solution and were stored in underground tanks prior to calcination. Sodium waste is generated during solvent clean-up and decontamination processes; it is segregated from other process solutions and is also stored in underground tanks prior to calcination.

During ICPP Pilot Plant Run 17 , the $30 \mathrm{~cm}$ pilot-plant calciner was used to generate calcine, at temperatures near $500^{\circ} \mathrm{C}(773 \mathrm{~K})$, from a non-radioactive blend of simulated fluorinel and sodium wastes; the blend ratio was $3.5: 1$ fluorinel to sodium, 
respectively. Table I lists the compositions of the simulated wastes and the composition of the $3.5: 1$ blended feed. The nonradioactive product generated during Run 17 was generated to simulate the highly radioactive fluorinel/sodium calcine generated at the New Waste Calcine Facility (NWCF). Since the radionuclide content in the calcine is less than 18 by weight ${ }^{\prime}$, this simulated calcine should be very representative of the highly radioactive product produced at NWCF.

Fluidized bed calcination at the NWCF is performed at temperatures near $773 \mathrm{~K}$; amorphous and crystalline phases are formed in the calcine. XRD has historically been used to determine the compositions of the crystalline phases present in the calcine; however, quantitative analytical determinations of the amorphous phase composition has never been done. Consequently, little is known about the quantity and composition of the non-crystalline phases. ICP has been the preferred method for determination of the concentrations of cations in the calcine. The calcine was solubilized prior to the ICP analyses by digestion in an acidic solution. The ICP analyses do not identify the anions present in the analyzed solution so it has been assumed that the cations exist in the calcine as oxide phases. The possible presence of alloys or multiple metal complexes were not generally considered during routine analyses.

- As of the end of $1986,430 \mathrm{~m}^{3}$ of $3.5: 1$ (fluorinel:sodium) blend calcine was on inventory at the ICPP. See reference 1 at the end of this document. 
Table I

Simulated Fluorinel Waste, Sodium Waste, and Blend Compositions

\begin{tabular}{|c|c|c|c|}
\hline Component & $\begin{array}{c}\text { Fluorinel } \\
\text { Waste } \\
\text { Composition } \\
\text { (Molar) }\end{array}$ & $\begin{array}{c}\text { Sodium } \\
\text { Waste } \\
\text { Composition } \\
\text { (Molar) }\end{array}$ & $\begin{array}{c}3.5: 1 \\
\text { Blend } \\
\text { Composition } \\
(\text { Molar) } \\
\end{array}$ \\
\hline $\mathrm{Zr}$ & 0.33 & * & 0.25 \\
\hline Al & 0.36 & 0.42 & 0.44 \\
\hline B & 0.19 & 0.008 & 0.15 \\
\hline $\mathrm{Ca}$ & $t$ & $t$ & 1.39 \\
\hline $\mathbf{F}$ & 2.54 & 0.039 & 1.98 \\
\hline $\mathrm{Na}$ & * & 1.39 & 0.31 \\
\hline $\mathrm{K}$ & * & 0.22 & 0.049 \\
\hline $\mathrm{Cd}$ & 0.11 & * & 0.086 \\
\hline $\mathrm{H}^{+}$ & 1.44 & 1.81 & 1.61 \\
\hline $\mathrm{SO}_{4}^{-2}$ & 0.07 & 0.065 & 0.069 \\
\hline $\mathrm{NO}_{3}^{-}$ & 2.05 & 4.73 & 2.65 \\
\hline $\mathrm{Cl}$ & * & 0.028 & 0.006 \\
\hline
\end{tabular}

t added to feed after blending

* not in feed

The formation of compounds other than oxides could result in a more favorable greater waste volume reduction, when the liquid waste is converted to calcine, if these other phases had smaller molar volumes. As waste volume reduction values are used to determine calcine storag? space currently being used (these numbers are compiled based on the formation of oxides), and to estimate future storage space requirements, it would be advantageous to have more information about the phase behavior of HLW calcines. With these uncertainties in mind, the product of 
the $30 \mathrm{~cm}$ Run 17 has been selected for further study to identify its phase behavior.

Because of the need to identify the chemical composition of both phases, Run 17 calcine was further examined by Scanning Electron Microscope Spectroscopy (SEM) and X-Ray Photoelectron spectroscopy (XPS) . 


\section{Experimental Equipment and Techniques}

Four analytical techniques were utilized to identify the composition of the phases, both crystalline and amorphous, present in a sample of Run 17 pilot plant calcine. The analytical techniques were selected based on avallability and the type of information (quantitative identification of cations or anions, identification of crystalline and amorphous phase compositions, and physical characteristics of the multiphase calcine particles) desired.

\section{X-Ray Powder Diffraction}

$x$-Ray diffraction was used to determine the crystalline phases in the calcine particles. Calcine analyzed by this method was ground to a fine powder with an automated alumina grinding system for 30 minutes, resulting in particle sizes less than 0.0056 inches. This grinding system ensures particle uniformity and sample homogeneity. The finely ground calcine was analyzed on a Prillips XRG-3000 $\theta 2 \theta$ (theta 2 theta) powder diffractometer with a scintillation detector. $\mathrm{x}$-rays were produced by a tube with a copper target operated at $30 \mathrm{kV}$ and $21 \mathrm{~mA}$. The wavelength of the radiation was nominally 1.542 angstroms, that characteristic of cu- $\alpha$ radiation, and was filtered through a nickel filter to remove beta radiation. 
The signal from the sample was filtered with a graphite monochrometer to prevent high backgrounds from $x$-ray fluorescence emissions. Reflection data were collected from $6^{\circ}$ to $76^{\circ}$ in $2 \theta$. Detection limits for most crystalline compounds in the complex calcine matrix ranged from 2-5 wt

Since each crystalline phase possesses a unique powder diffraction pattern, the data obtained from Run 17 calcine was used as a "fingerprint" to identify the crystalline phases present in the material analyzed.

\section{Induotively Coupled Plasma Emission 8peotroscopy, ICP}

ICP analyses were performed using a Jobin Yvon model 38 spectrometer. The atomic emission spectrum of the sampled material was produced by an inductively coupled plasma torch utilizing Ar $(g)$ as the cooling gas. The sample analyzed was prepared by dissolving a known mass of Run 17 calcine

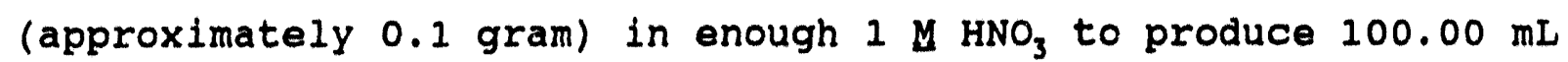
of solution. The resulting solution was diluted with $18 \mathrm{HNO}_{3}$ (by volume) to bring the concentrations of the cations in the solution within the calibration range of the instrument. The cations were analyzed sequentially from duplicate aliquots of solution removed from the same sample. 


\section{soanning Electron Microscope spectroscopy, 8EX}

A random sample of Run 17 calcine particles was mounted in an epoxy resin under vacuum to remove all entrained "air" from the porous calcine and epoxy resin. This mount was allowed to cure overnight at room temperature. A thin wafer was cut from the mount to give a good cross section of the calcine particles. This wafer was ground (with silicon carbide papers at 240,320 , 400 , and 600 grit and paraffin oil used as the lubricant) and polished (with an organic solvent in which the calcine is insoluble).

Final polishing was performed using 6-9 micron diamond suspensions in nylon cloth, followed by polishing with 1 micron diamond suspensions in synthetic rayon cloth. Samples were then mounted on a glass slide with the polished side down. The glass mounted sample was cut with a slow speed diamond saw to 30 microns. The "cut" or unpolished side of the glass mount was then polished as previously described. The resulting wafer had a thickness of $10 \mathrm{um}$. The thin, mounted sample was analyzed with an Amray Model 1830 SEM equipped with a Kevex Delta 5 EDS system; the pressure in the sample chamber was near $10^{-6} \mathrm{~mm} \mathrm{Hg}$ during each analysis.

Calcine homogeneity was determined by randomly selecting three calcine particles of different sizes, large ( $>400 \mathrm{um}$ ), medium 
$(100-300 \mathrm{um})$ and small (< $100 \mathrm{um})$ for analyses. Points across the diameter of each particle were randomly selected and analyzed. The area of each point was approximately $2 \mathrm{um}^{2}$. Comparison of the compositions at various points on a single particle provides information pertaining to the homogeneity of that particle. These particles where then "mapped" to determine the elemental composition across the diameter of the particles. Mapping activities provide data that give the distributions of Individual elements across the calcine particle.

Fifteen particles, ranging in size from large to small, were also analyzed to quantitatively determine the cross-section surface composition of each particle. These analysis were performed to identify possible relationships between particle size and chemical composition.

\section{X-Ray Physical Electron 8pectroscopy, XPB}

Run 17 calcine was analyzed by XPS to determine the chemical composition of both amorphous and crystalline phases; an Esca Model 5300 x-ray spectrometer was used for the analyses. The calcine sample was prepared for analysis by grinding it to a fine powder with an alumina mortar and pestle. A portion of the ground material was then placed between two sheets of indium metal to immobilize the powder sample between the two sheets of indium foll. The "indium mount" was used because it would not 
interfere with the detection of elements in the calcine as indium was not one of the elements present in the calcine sample.

\section{Analytioal Methode Used to Dotermine Non-Motal Concentratione}

\section{Chloride}

Chloride consentration in the calcine was determined by $x$-ray fluorescence using a Ph1llips FW1404 X-ray spectrometer. A known amount of standard chloride solution ( $500 \mathrm{mls}$ of $10 \mathrm{ug} \mathrm{cl} / \mathrm{ml}$ ) was added to one sample of Run 17 calcine, an equal volume of water with no chloride was added to another sample of Run 17 calcine. The mixtures were dried at $65^{\circ} \mathrm{C}$. This procedure was repeated for different known chloride additions. The calcine was finely ground with the same automated grinding system used for XRD analysis. Following chloride or water addition and grinding, 4 grams of each sample were pressed into a pellet using a 7 ton press. The pellets were then analyzed for chloride by $x$-ray Fluorescence spectroscopy.

\section{rluoride}

An Orion 94-09 Fluoride Ion Selective Electrode was used for fluoride determinations. Calcine sample preparations for fluoride determinations involved a calcine fusion with sodium hydroxide, followed by dissolution of the fused sample to form 
aqueous solutions. The fusion converts the fluoride in the calcine, present as calcium fluoride, into buffer-soluble sodium fluoride. The fusion was performed by heating a mixture of known masses of sodium hydroxide and calcine, in a zirconium cructible, at temperatures less than $773 \mathrm{~K}$.

Just as in the chloride analysis, the method of standard addition was used to determine the concentration of fluoride in calcine. The concentration of fluoride was then determined by comparing the electrode responses from the calcine-containing solutions to a standard titration curve (the titration curve for a sample containing only the standard-addad amount of fluoride); the fluoride content of the calcine was computed from the difference. other metal lons present in the solution are prevented from interfering with fluoride detection by buffering the samples to a $\mathrm{pH}$ of 7 using sodium citrate, sodium chloride, and triethanolamine.

\section{Nitrate}

Nitrate in the calcine was determined by the kjeldahl method. The calcine was prepared for analysis by grinding it to a fine powder to insure wetting of the surface of the particles by the concentrated sodium hydroxide solution that was used to dissolve/leach the nitrate from the calcine. Nitrate in the sodium hydroxide media was reduced to ammonla with a Devarda's 
alloy, with the composition $508 \mathrm{Cu}, 458 \mathrm{Al}$, and $58 \mathrm{zn}$. The ammonia was distilled into a boric acid solution and titrated with sulfuric acid to determine the amount of nitrogen present in the sample; the nitrate content was subsequently computed from the nitrogen result.

\section{Bulfur}

The calcine was prepared for analysis by first grinding it to a fine powder followed by heating $3-4 \mathrm{mg}$ of ground sample to $1023 \mathrm{~K}$, under a flowing gas stream, in the presence of vanadium pentoxide. Vanadium pentoxide acts as a catalyst that speed the reduction of the condensed sulfur-containing species to $\mathrm{sO}_{2}(\mathrm{~g})$. The volatilized sulfur-containing vapor was then swept over a hot bed of copper oxide to ensure complete conversion sulfur to $\mathrm{SO}_{2}(g)$. The $\mathrm{SO}_{2}(g)$ in the gas stream was coulometrically determined using a UIC Inc. Coulometer. 


\section{Results and Disouseion}

ICP and Non-Metal Doterminations

Determinations of all metals known to be present in the calcine, except $\mathrm{Sr}, \mathrm{Hg}, \mathrm{Na}$, and $\mathrm{K}$, were performed by Induct Ively-Coupled Plasma Emission spectroscopy. The $\mathrm{Sr}, \mathrm{Hg}, \mathrm{Na}$, and $\mathrm{K}$ concentrations were determined by Atomic Emiseion spectroscopy, fluoride was determined by fluoride ion speciflc electrode, chloride was determined by $x$-ray fluorescence, sulfur was determined by a colorimetric technique, and nitrate was determined by the kfeldahl method. I'he results of these analyses, presented as elemental and lonic weight percents $(w / 0)$, are tabulated in Table II.

These results provide valuable insights toward understanding the gross composition of the calcine, however, they do not provide information regarding the phase composition of the calcine, nor do they contribute to determining the spatial distributions of these elements in the solid calcine particle.

ICP, AA, and anionic data are useful for identifying distinct phases when used in tandem with XRD and XPS results. XRD results can be used to ldentify the crystaline phases present in a sample; XPS results can be used to identify the bonding of elements present in a substance. Since the chemical matrix in 
Table II

Element concentrations in Run 17 Calcine

\begin{tabular}{|c|c|}
\hline Element & Wt in Calcine \\
\hline Al & 5.61 \\
\hline B & 0.96 \\
\hline $\mathrm{Ca}$ & 24.9 \\
\hline $\mathrm{cd}$ & 4.63 \\
\hline $\mathrm{Ce}$ & $<0.0069$ \\
\hline $\mathrm{Cr}$ & 0.99 \\
\hline $\mathrm{Fe}$ & 0.33 \\
\hline $\mathrm{Mn}$ & 0.088 \\
\hline $\mathrm{N} 1$ & 0.11 \\
\hline se & $<0.24$ \\
\hline sr & 0.064 \\
\hline $2 r$ & 13.1 \\
\hline C* & $<0.01$ \\
\hline $\mathrm{Hg}$ & $<0.0005$ \\
\hline $\mathrm{Na}$ & 3.5 \\
\hline $\mathbf{k}$ & 0.80 \\
\hline Cl & $2.45 \mathrm{ppm}$ \\
\hline$F$ & 17.3 \\
\hline$s$ & 1.07 \\
\hline $\mathrm{NO}_{1}^{\circ}$ & 5.87 \\
\hline
\end{tabular}

note: Remainder of mass balance is assumed to be oxygen 
calcine is complex, XRD and XPS results ldentify number of phases that may be present in the calcine. Consideration of ICP, $A A$, and anionic results in tandem with the XRD and XPS results can restrict the possible phases that may be present in the calcine; this type of analysis will be presented later in this report.

\section{X-Ray Powder Diffraction Resulte}

The X-ray diffraction data were collected as analog data, as a diffractogram (Figure 1), and as digital data that were stored in a computer dick ille. The diffractogram is a plot of intensity (I) of $X$-rays, in counts-per-second (Cps) as measured by the scintillation detector, versus the angle of reflection, $2 \theta$, in degrees $(\cdot)$. The digltal data were compared to a computer database of $x$-ray diffraction data for a large number of crystalline phases, and the most likely matches with the data were 1dentifled.' As a result of the database search/comparison activity, the crystaline phases identifled, as those most likely present in the sample, were $\mathrm{CaF}_{2}, \mathrm{Cds}, \mathrm{ZrO}_{2}$, and $\mathrm{NaNO}_{3}, \mathrm{less}$ likely phases included $\mathrm{Sr}_{3} 2 \mathrm{r}_{2} \mathrm{O}_{7}, \mathrm{Na}(\mathrm{Ca}, \mathrm{Sr})_{3} \mathrm{Al}_{3} \mathrm{~F}_{16}$, and $\mathrm{Ca}_{3}(\mathrm{OH})_{2} \mathrm{Si}_{3} \mathrm{O}_{8}$ (which could also be represented by the formula $\mathrm{Ca}_{3} \mathrm{Si}_{3} \mathrm{O}_{9} \bullet \mathrm{H}_{2} \mathrm{O}$ ).

- The Fein/Marquardt search Program includes diffraction patterns for all known inorganic crystalline phases. 


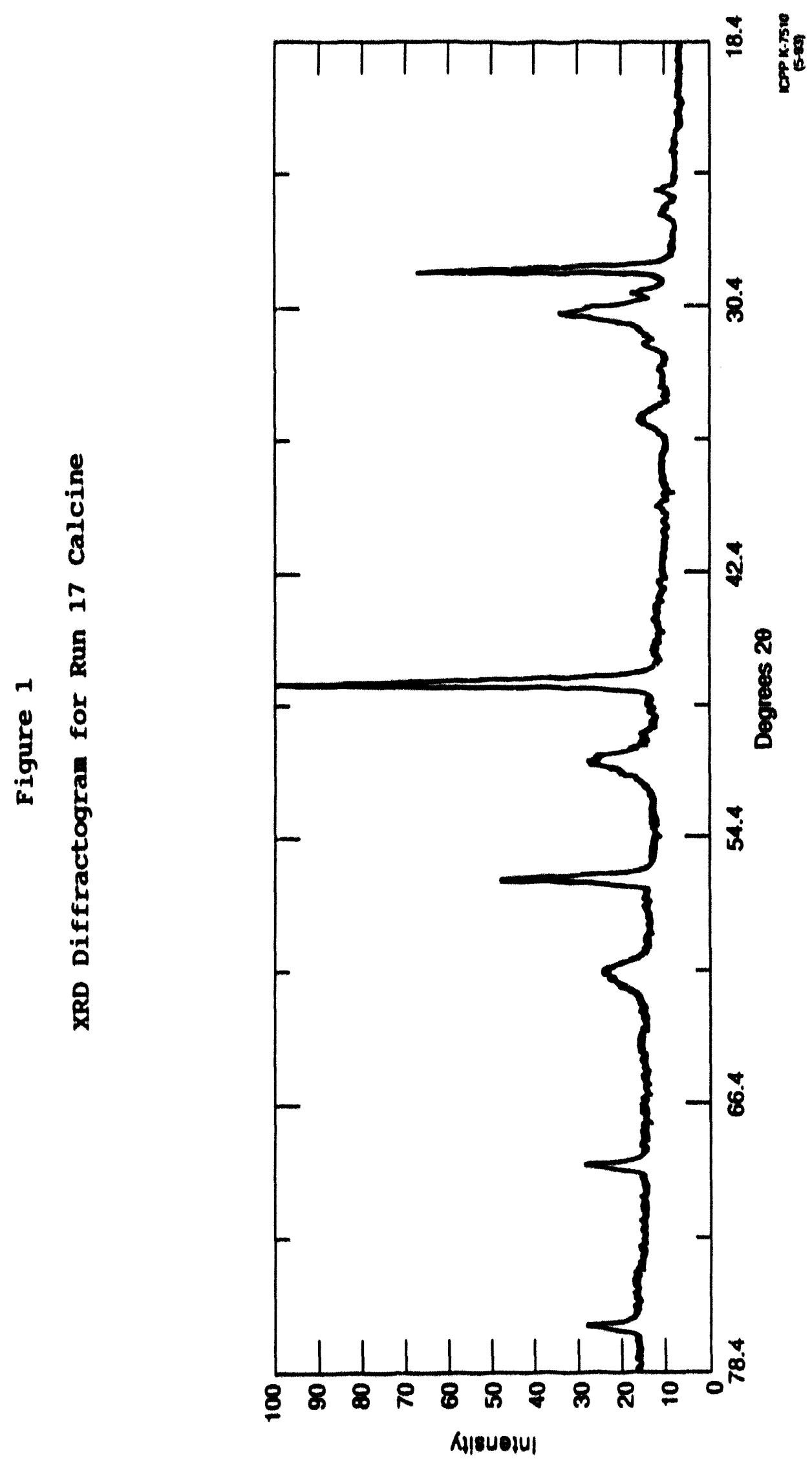


Since the detection limit for XRD is approximately $5 \mathrm{w} / 0$, and the ICP result showed only 0.064 wt $8 \mathrm{Sr}$ in the calcine, the presence of the strontium compounds, $\mathrm{NaSr}_{3} \mathrm{Al}_{3} \mathrm{~F}_{16}$ and $\mathrm{Sr}_{3} \mathrm{Zr}_{2} \mathrm{O}_{7}$, is precluded unless the sample was sr contaminated. As no likely method of sr-contamination has been identified, it is assumed that these phases are not present in the calcine. silicon analysis was not performed by ICP because of the inherent problems with 1ts determination (high background levels and negative interferences caused by $s i$ precipitation during sample preparation). As a consequence of this, and the fact that silicon 1 s present in water and dust, it is possible that the calcine feed was sicontaminated. It is likely, therefore, that the phases CaF2, CdS, $\mathrm{ZrO}_{2}, \mathrm{NaNO}_{3}, \mathrm{NaCa}_{3} \mathrm{Al}_{3} \mathrm{~F}_{16}$, and $\mathrm{Ca}_{3} \mathrm{Si}_{3} \mathrm{O}_{8}(\mathrm{OH})_{2}$ are present in Run 17 calcine.

XRD results, which are effective for identifying major phases but not quantities of each phase, can be used in conjunction with results of ICP and anionic analyses to provide an upper limit on the quantities off each major crystalline phase, neglecting the amorphous and minor crystalline phase portions. It is not possible to Identify the minor phases because the $x$-ray powder diffraction method lacks sensitivity and the amorphous material in the calcine samples produces $x$-ray scattering of high amplitude that are quite broad and effectively mask the reflections from minor crystalline phases in the calcine. Because of the limitations of ICP, XRD and the techniques used to 
determine the anions, SEM and XPS analyses were performed on samples of Run 17 calcine.

\section{BEM Results}

The calcine particles studied by SEM were randomly selected from the prepared sample. Figure 2, an image produced by backscattered $20 \mathrm{kV}$ electrons that shows the particles sizes magnified by a factor of 50 (50x magnification), shows the three calcine particles, labelled 1, 2, and 3 that were selected for point by point analysis (analysis of a surface area of $2 \mathrm{um}^{2}$ ). The surface areas of particles, 1, 2, and 3 are approximately $2 \times 10^{5} \mathrm{um}^{2}, 3 \times 10^{4} \mathrm{um}^{2}$, and $8 \times 10^{3} \mathrm{um}^{2}$, respectively. 


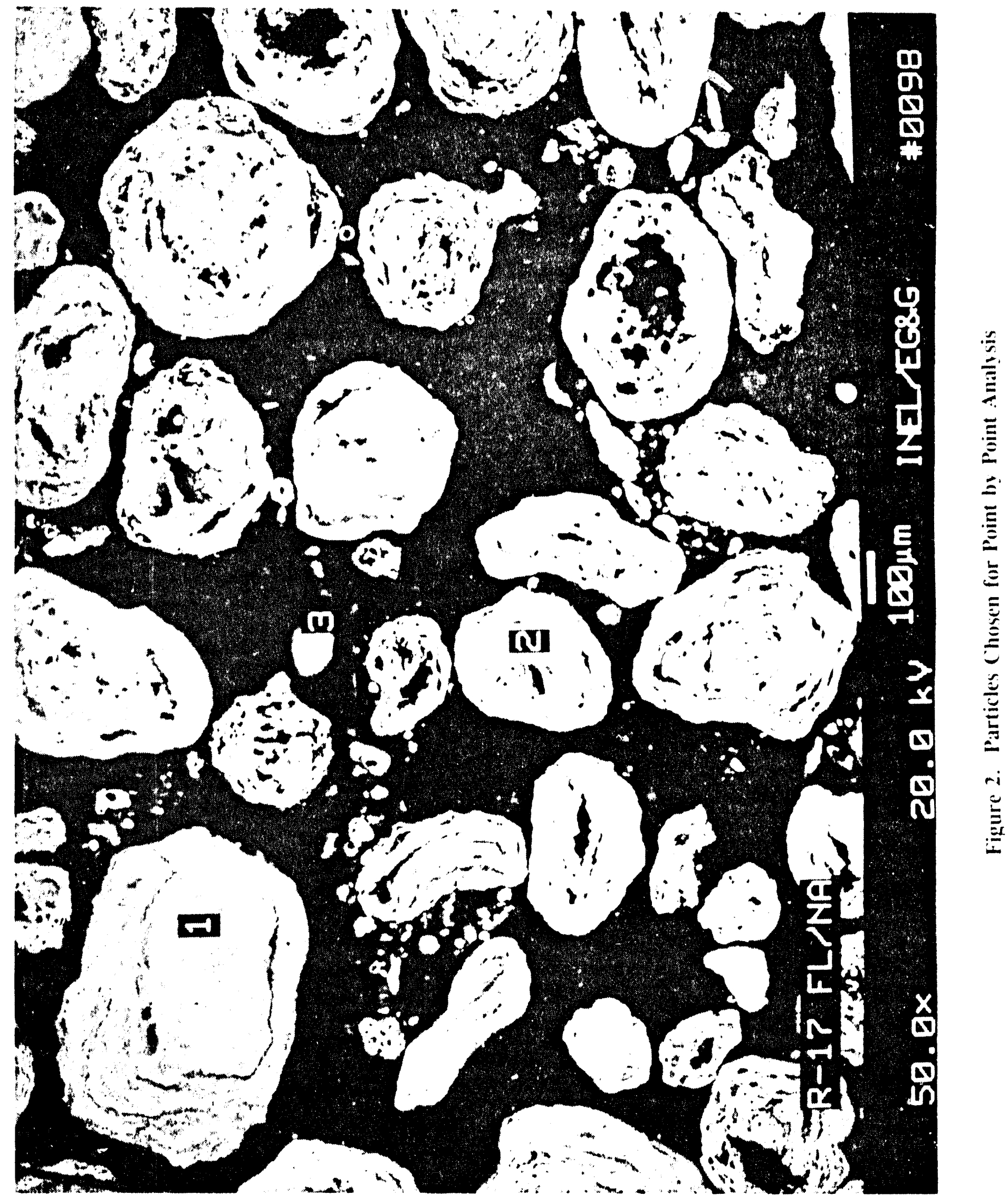


The points selected for point by point analysis of Particle 1 are shown in Figure 3. This figure shows Particle 1 magnified $200 \mathrm{x}$ and identifies the five points at which data were collected. The light grey areas of the image indicate crystalline material while the brighter areas of this picture are amorphous regions; this image shows clearly the phase non-homogenelty of the particle. The layered structure of the particle is an artifact of the calcination process. Growth of particles during calcination is a result of the deposition of material on the surface of the particle. Due to the kinetics of the deposition process, some of the layers are crystalline, while others are amorphous.

Table III contains point by point composition data for Particle 1; Appendix A contains the raw SEM data used to generate Table III. The data tabulated for the elements $\mathrm{O}, \mathrm{F}, \mathrm{Na}, \mathrm{Al}, \mathrm{S}, \mathrm{K}, \mathrm{Ca}$, $\mathrm{Cr}, \mathrm{Mn}, \mathrm{Zr}$, and $\mathrm{Cd}$ were collected at the five numbered points identified on Figure 2. There are distinct differences in the chemical compositions of each point. The point to point difference in composition is expected due to the considerations discussed in the preceding paragraph. The weight percent data in Table III were converted to moles and the molar quantities were used to determine the stoichiometcy at each point. ${ }^{2}$ 


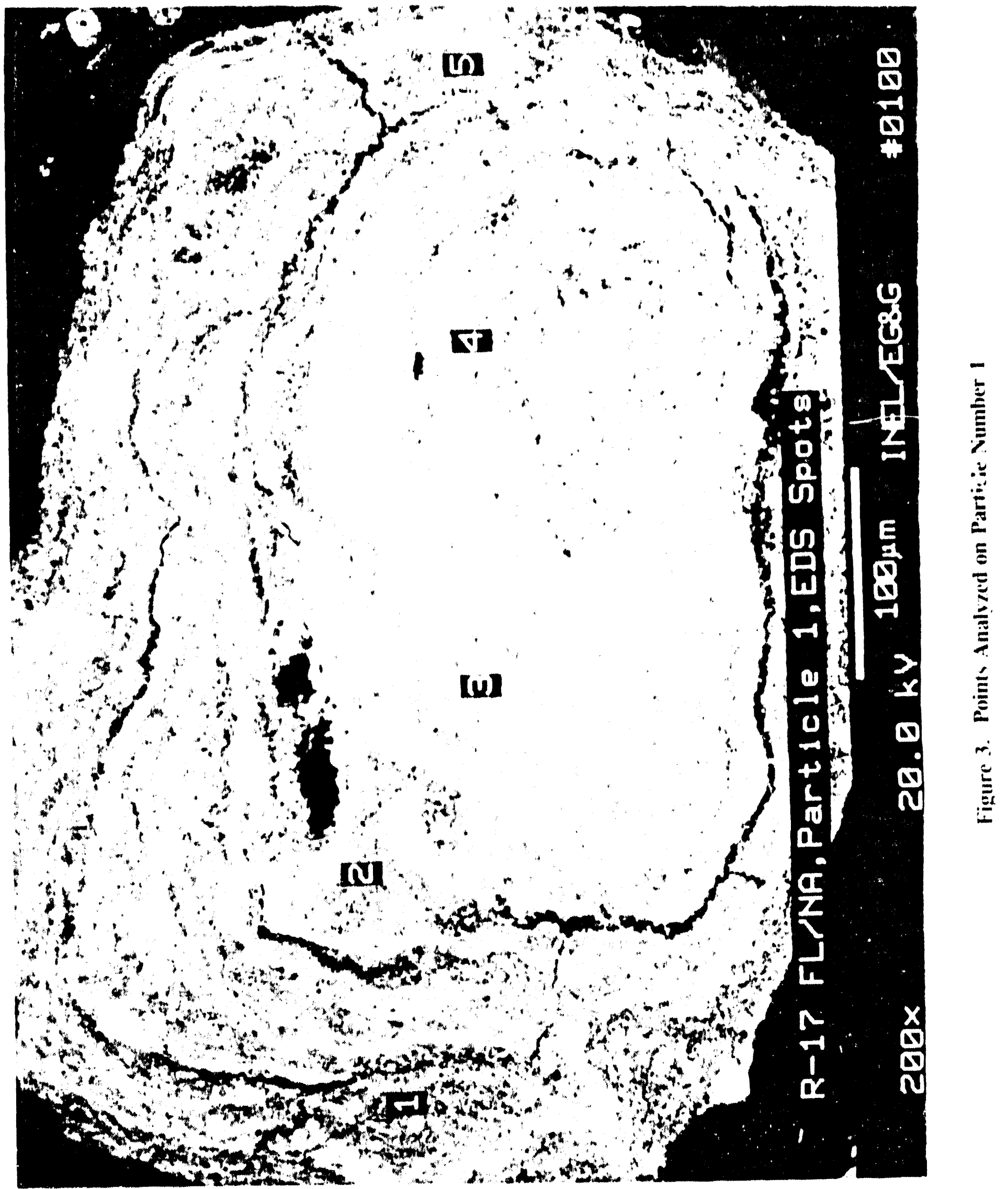


Table III

SEM Data

Elemental Welght Percents for Particle 1

From Point Analysis

\begin{tabular}{|c|c|c|c|c|c|c|}
\hline \multirow[t]{2}{*}{ Element } & \multicolumn{6}{|c|}{ Point Number } \\
\hline & 1 & 2 & 3 & 4 & 5 & $\begin{array}{c}\text { Average } \\
\text { Wtf }\end{array}$ \\
\hline 0 & 11.80 & 28.81 & 38.38 & 49.56 & 34.24 & $\begin{array}{r}32.56 \\
+\quad 13.88\end{array}$ \\
\hline $\mathbf{F}$ & 41.23 & 28.86 & 16.15 & 15.69 & 32.95 & $\begin{array}{r}26.98 \\
+\quad 11.03 \\
\end{array}$ \\
\hline $\mathrm{Na}$ & * & 1.84 & $\star$ & 2.53 & * & $\begin{array}{r}0.87 \\
+\quad 1.22 \\
\end{array}$ \\
\hline Al & 1.51 & 2.05 & 13.50 & 9.44 & 8.32 & $\begin{array}{r}6.96 \\
+\quad 5.11 \\
\end{array}$ \\
\hline $\mathbf{s}$ & $\star$ & 2.37 & $\star$ & $\star$ & * & $\begin{array}{r}0.47 \\
+\quad 1.06 \\
\end{array}$ \\
\hline $\mathbf{K}$ & 0.31 & 0.33 & $\star$ & * & * & $\begin{array}{r}0.13 \\
\pm \quad 0.18 \\
\end{array}$ \\
\hline $\mathrm{Ca}$ & 39.93 & 42.14 & 10.55 & 22.26 & 22.88 & $\begin{array}{r}27.55 \\
+\quad 13.28 \\
\end{array}$ \\
\hline $\mathrm{Cr}$ & 0.13 & 0.30 & 0.43 & $\star$ & 0.58 & $\begin{array}{r}0.29 \\
+\quad 0.23 \\
\end{array}$ \\
\hline$M n$ & * & $\star$ & $\star$ & * & 0.13 & $\begin{array}{r}0.026 \\
+\quad 0.058 \\
\end{array}$ \\
\hline $\mathrm{Zr}$ & 4.85 & 2.88 & 24.62 & 14.57 & 19.09 & $\begin{array}{r}13.20 \\
\pm \quad 9.26\end{array}$ \\
\hline $\mathrm{cd}$ & 1.58 & 1.36 & 15.05 & 6.46 & 7.57 & $\begin{array}{r}6.40 \\
+\quad 5.59 \\
\end{array}$ \\
\hline
\end{tabular}

1 The raw data are tabulated in Appendix $A$.

2 Precision of each measured weight percent value is about 2\%; uncertainty of each measured weight percent value is about $10 \%$.

* None Detected 
The relative qualitative elemental abundances at point 1 , in terms of decreasing mole quantities, are $\mathrm{F}, \mathrm{Ca}, \mathrm{O}, \mathrm{Al}, \mathrm{Zr}, \mathrm{Cd}, \mathrm{K}$, and $\mathrm{Cr}$. The calcium to fluoride ratio $(\mathrm{Ca} / \mathrm{F})$ of 0.46 is only slightly less than the value to be expected if all the fluorine were present as fluoride in $\mathrm{CaF}_{2}(\mathrm{~s})$. It is supposed that the metals, other than calcium, are present primarily as oxides, although some crystalline fluorides and nitrates, as well as amorphous material, may also be present.

Point 2 of Particie 1 is located in a region of the particle that contains excess calcium as compared to the $\mathrm{Ca} / \mathrm{F}$ ratio expected for $\mathrm{CaF}_{2}$. It is likely that some of the calcium in this region is present as CaO. The minor metals in this region are probably also present as crystalline oxides and nitrates and amorphous material.

The region in which point 3 is located is compositionally quite different from those containing points 1 and 2 . This region (that which includes point 3) has considerable excess fluoride as compared to the $\mathrm{Ca} / \mathrm{F}$ ratio of $\mathrm{CaF}_{2}$. It is most likely that all the calcium in this region is present as $\mathrm{CaF}_{2}$; the remaining fluoride is distributed among the other metals as crystalline fluoride phases or amorphous materials.

Point 4, like point 2 , has an excess of calcium compared to the $\mathrm{Ca} / \mathrm{F}$ ratio of $\mathrm{CaF}_{2}$. The high concentrations of $\mathrm{Al}, \mathrm{Zr}$, and $\mathrm{Cd}$ in 
this region, as compared to the three previously discussed points, suggests that these metals are present in crystalline and/or amorphous phases that probably do not contain much fluoride.

Point 5, like point 3, has an excess of fluoride compared to the $\mathrm{Ca} / \mathrm{F}$ ratio of $\mathrm{CaF}_{2}$. It is most likely that all the calcium exist as $\mathrm{CaF}_{2}$, the remaining fluoride is probably distributed between the $C d, A 1$, and $2 x$. The excess fluoride concentration at points 3 and 5 seem to be correlated with high zirconium concentrations. An actual correlation between high fluoride concentrations and high zirconium concentration has not been previously identifled, but this result may indicate that the formation of $2 \mathrm{rF}_{4}$ is favorable as compared to $\mathrm{AlF}_{3}$ and $\mathrm{CdF}_{2}$.

Figure 4 is a picture of Particle 2 at $300 \mathrm{X}$ magnification. At high magnification, the distribution of the amorphous and crystalline phases is more pronounced than for the lower magnification image of Particle 1. Areas where point analysis where taken are also shown in this figure. Table IV lists the concentrations of the elements found at each point. As in the point analysis of Particle 1, points analyzed on Particle 2 differ considerably. Appendix B contains the raw SEM data used to generate Table IV. 


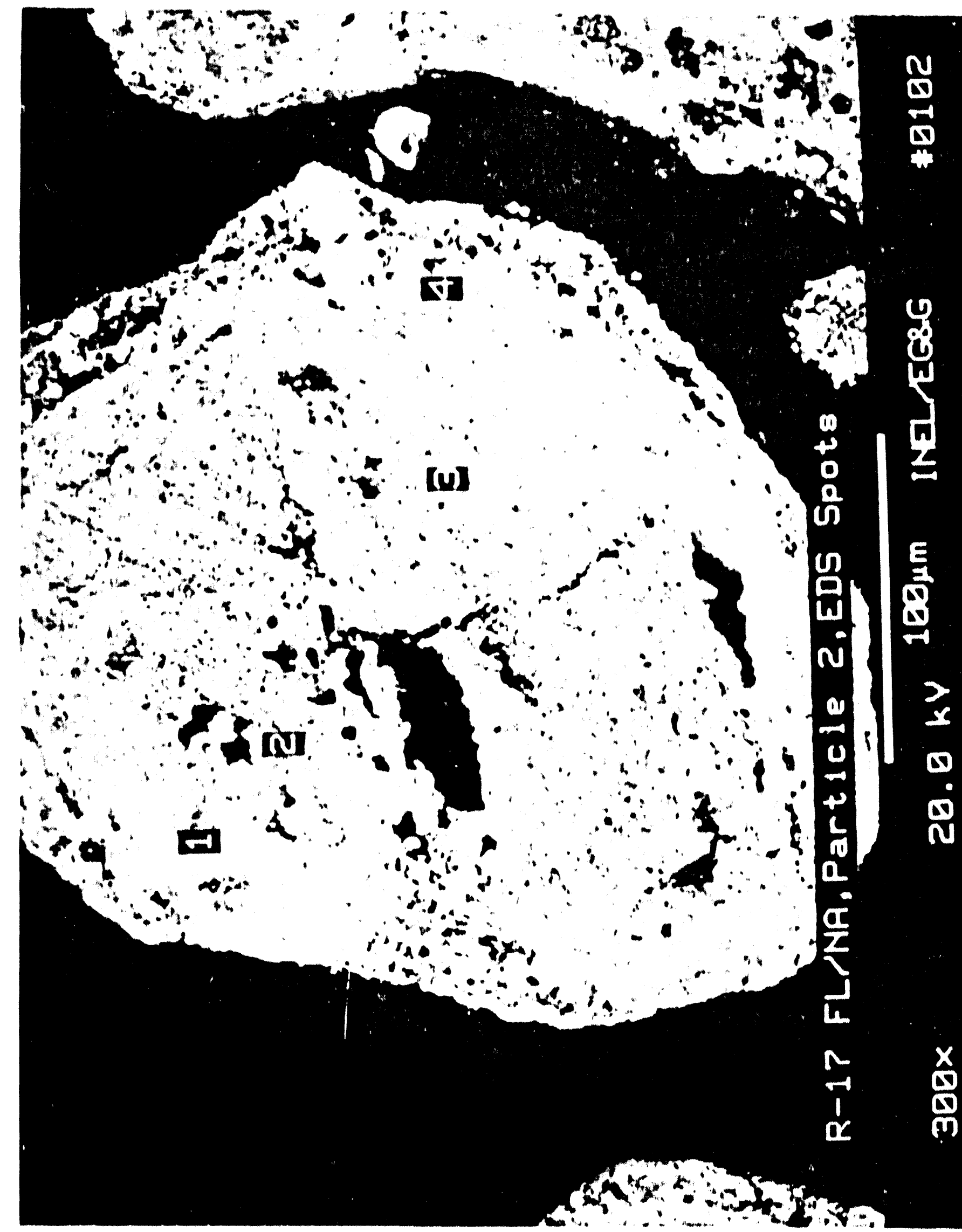


Table IV

SEM Dato

Welght Percent Elements in Particle 2

From Polnt Analyeis

\begin{tabular}{|c|c|c|c|c|c|}
\hline \multirow[t]{2}{*}{ Element } & \multicolumn{5}{|c|}{ Point Number } \\
\hline & 1 & 2 & 3 & 4 & $\begin{array}{c}\text { Average } \\
\text { Wts }\end{array}$ \\
\hline 0 & 54.82 & $\star$ & 54.62 & 19.55 & $\begin{array}{r}32.25 \\
+\quad 27.15 \\
\end{array}$ \\
\hline$F$ & 9.76 & 45.84 & 6.43 & 43.74 & $\begin{array}{r}26.44 \\
+\quad 21.25 \\
\end{array}$ \\
\hline $\mathrm{Na}$ & $\star$ & $\star$ & 0.63 & $\star$ & $\begin{array}{r}0.16 \\
+\quad 0.31 \\
\end{array}$ \\
\hline$A 1$ & 14.00 & 0.88 & 14.22 & 4.42 & $\begin{array}{r}8.38 \\
+\quad 6.77 \\
\end{array}$ \\
\hline $\mathbf{s}$ & $\star$ & $\star$ & $\star$ & $\star$ & $\begin{array}{r}0.00 \\
\pm \quad 0.00 \\
\end{array}$ \\
\hline$K$ & $\star$ & 0.32 & $\star$ & $\star$ & $\begin{array}{r}0.08 \\
+\quad 0.16 \\
\end{array}$ \\
\hline $\mathrm{Ca}$ & 13.17 & 44.74 & $18 \cdot 27$ & 38.84 & $\begin{array}{r}28.76 \\
+\quad 15.39 \\
\end{array}$ \\
\hline $\mathrm{Cr}$ & $\star$ & $\star$ & $\star$ & * & $\begin{array}{r}0.00 \\
\pm \quad 0.00 \\
\end{array}$ \\
\hline$M n$ & 0.24 & $\star$ & $\star$ & $\star$ & $\begin{array}{r}0.06 \\
\pm \quad 0.12 \\
\end{array}$ \\
\hline $2 r$ & 25.83 & 2.72 & 11.97 & 4.60 & $\begin{array}{r}11.28 \\
+\quad 10.49 \\
\end{array}$ \\
\hline$c d$ & 11.21 & 1.32 & 12.52 & 3.18 & $\begin{array}{r}7.06 \\
+\quad 5.63 \\
\end{array}$ \\
\hline
\end{tabular}

The raw data are tabulated in Appendix $B$.

2 Precision of each measured weight percent value is about 28: uncertalnty of each measured weight percent value is about 108 .

* None detected 
Point 1 on particle 2 has an excess of calclum as compared to the $\mathrm{Ca} / \mathrm{F}$ ratio of $\mathrm{CaF}_{2}$. High aluminum and zirconium concentratione In the region might lead to a diatribution of fluorlde among these metals but $1 \mathrm{t}$ is more $11 \mathrm{kely}$ that these elemente are present, in cryetalline phases, as oxides, or as amorphous phases. Unlike points 3 and 5 of Particle 1 , there is not an excess of eluoride with the high alrconlum concentration, suggesting there is no correlation between excese eluorlde with hlgh zirconlum concentrations. Because of the hlgh concentrations of eirconium and aluminum, it is difficult to determine the extent of the metal-iluorlde formation compared to the metal-oxide formation, but it is $11 \mathrm{kely}$ that moet of the eluoride is present as crystalline CaF ${ }_{2}$

Point 2 on this particle has a Ca/F ratio slightly lese than that of $\mathrm{CaF}_{2}$. When the moles of excese fluorlde are compared to the moles of aluminum, zirconium, and cadmium found in this region, there is stolchlometrlcally enough fluorlde to form $A_{1} F_{3}$, $2 F_{4}$, and $\mathrm{CdF}_{2}$. The formation of these metal-fluoride compounds seems likely because of the lack of oxygen in the ragion.

Excess calclum, as compared to the Ca/F ratlo of $\mathrm{CaF}_{2}$, is found at point 3. High concentrations of aluminum, zirconlum, and cadmlum are also present, leading to the conclusion that crystalline, oxide and/or nitrate phases, and/or amorphous phases are present in the region. 
At point 4 there 1e excess fluoride as compared to the Car, atolohiometry. Thie area moat likely is Car, with minor concentratione of $A 1 F_{3}, 2 r F_{4}$ and/or $C_{d} F_{2}$. The hypothesized presence of these other metal-fluorlde compounds is eupported by the low concentration of oxygen, which meane that oxide- and nitrate-containing phases are present only in emall concentrations.

Figure 5 is a pleture of particle 3 at a magnification of $1000 x$. Th1. particle has a higher density of the amorphous phase than the two larger particles, 1 and 2 . If point 2 is representative of the amorphous areas, $2 \mathrm{rO}_{2}$ could be the primary constituent in the amorphous phase, as could a nitrate-contalning phase. Table $V$ liste the concentrations of the elemente found at each point. Appendix C containe the raw SEM data used to generate Table $V$.

Point 1 on Particle 3 contains very nearly tolchiometric amounts of fluoride and calclum as compared to the ldeal composition of $\mathrm{CaF}_{2}$. The minor constituents of this region are most likely metal oxides or nitrates, crystalline or amorphous, present in very low concentrations, as indlcated by the lack of oxygen in this region.

Point 2 ia probably $\mathrm{zrO}_{2}$, with a minor amounts of $\mathrm{CaO}_{1} \mathrm{Al}_{2} \mathrm{O}_{3}$, and cdo, although nitrates might also be present. The relative stabllity of the crystalline nitrates, as compared to oxides, 


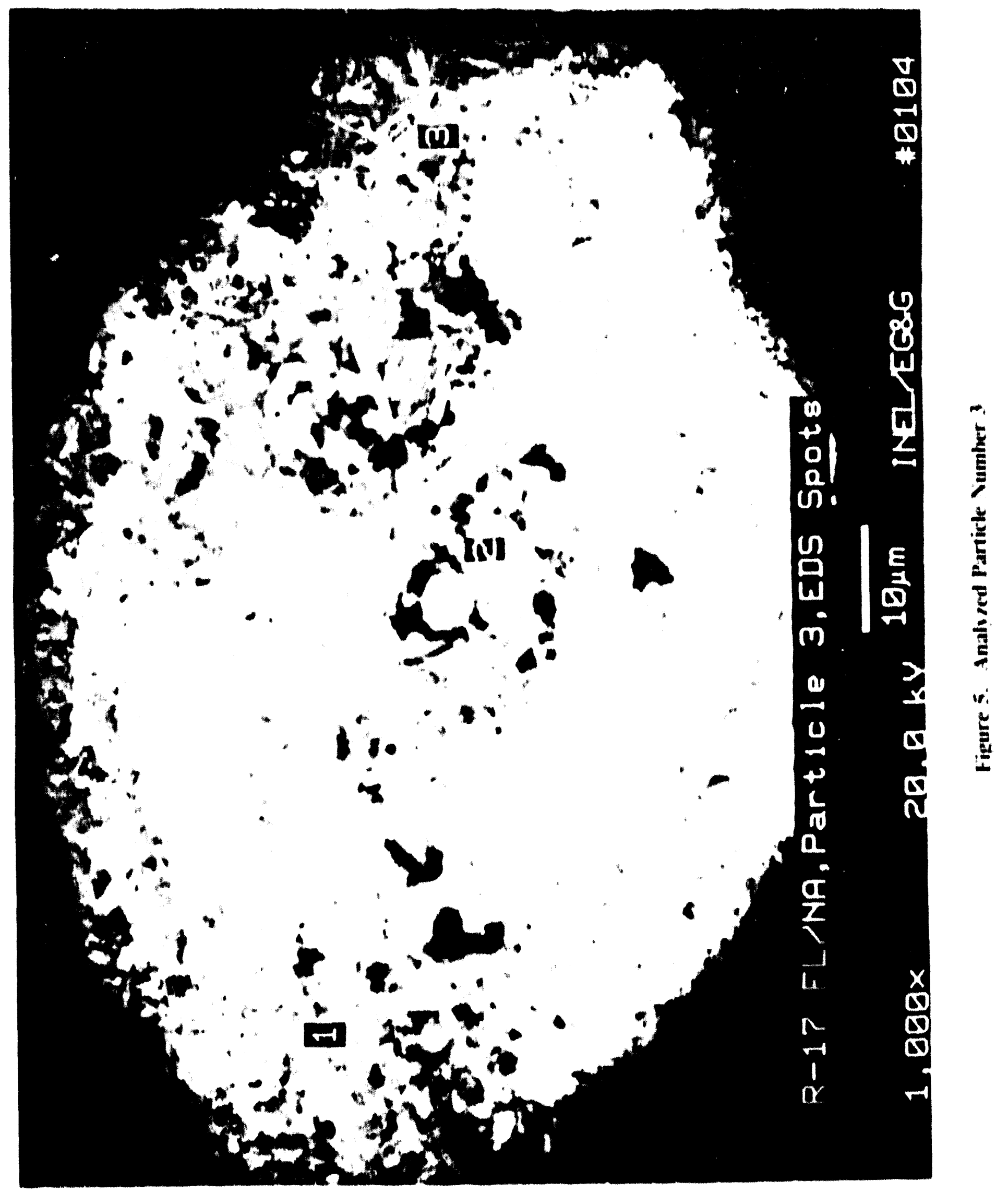




\section{Table $v$}

SEM Data

Weight Percent Elements in Particle 3

From Polnt Analysis

\begin{tabular}{|c|c|c|c|c|}
\hline \multirow[t]{2}{*}{ Element } & \multicolumn{4}{|c|}{ Point Number } \\
\hline & 1 & 2 & 3 & $\begin{array}{c}\text { Average } \\
\text { Wt: }\end{array}$ \\
\hline 0 & 7.91 & 49.54 & 50.88 & $\begin{array}{r}36.11 \\
\pm \quad 24.43\end{array}$ \\
\hline$F$ & 37.22 & $\bullet$ & $\star$ & $\begin{array}{r}12.41 \\
+\quad 21.49 \\
\end{array}$ \\
\hline $\mathrm{Na}$ & $\star$ & $\star$ & 2.76 & $\begin{array}{r}0.92 \\
\pm \quad 1.59 \\
\end{array}$ \\
\hline Al & 0.94 & $5.8 ?$ & 0.32 & $\begin{array}{r}2.36 \\
\pm \quad 3.01 \\
\end{array}$ \\
\hline $\mathbf{s}$ & $\star$ & $\star$ & 4.15 & $\begin{array}{r}1.38 \\
+\quad 2.40 \\
\end{array}$ \\
\hline $\mathbf{K}$ & 0.35 & $\bullet$ & 0.20 & $\begin{array}{r}0.18 \\
+\quad 0.18 \\
\end{array}$ \\
\hline $\mathbf{C a}$ & 43.00 & 10.80 & 21.18 & $\begin{array}{r}24.99 \\
+\quad 16.44 \\
\end{array}$ \\
\hline $\mathrm{cr}$ & 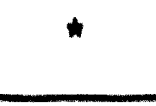 & 1.01 & $\star$ & $\begin{array}{r}0.34 \\
\pm \quad 0.58 \\
\end{array}$ \\
\hline Mn & $\star$ & $\star$ & $\star$ & $\begin{array}{r}0.00 \\
+\quad 0.00 \\
\end{array}$ \\
\hline $2 r$ & 5.31 & 39.40 & 1.51 & $\begin{array}{r}15.41 \\
+\quad 20.87 \\
\end{array}$ \\
\hline cd & 1.87 & 7.38 & 0.63 & $\begin{array}{r}3.29 \\
+\quad 3.59\end{array}$ \\
\hline
\end{tabular}

1 The raw data are tabulated in Appendix $c$.

2 Precision of each measured welght percent value is about 28 i uncertainty of each measured weight percent value is about 108.

- None Detected 
suggests that amorphous regions might be high in nitrate; no fluoride was detected in this region.

An evaluation of point 3 shows the multiphase character of this particle. This point is probably quite high in CaO, with minor amounts of $\mathrm{Al}_{2} \mathrm{O}_{3}$ and $\mathrm{ZrO}_{2}$, although it is not clear if these are amorphous or crystalline phases; it is also possible that nitrates might be present. The relatively high concentration of sulfur in this region indicates a great likelihood that cds (found by XRD analysis), as well as sulfate phases that possibly include $\mathrm{K}_{2} \mathrm{SO}_{4}$, are present. Excess sulfur would still exists if all the potassium and cadmium formed sulfur compounds, leading to the conclusion that other sulfate phases, such as $\mathrm{CaSO}_{4}$, are probably present.

From the point by point analyses done on Particles 1,2 , and 3 it is seen that the compositions differ across the cross-sectional surfaces of the sample particles. These results clearly indicate that the particles are inhomogeneous and multiphasic in character. Analyses were performed on fifteen randomly chosen particles of different sizes to deduce any correlation between gross composition and particle size; Figure 6 is a photograph labelled to identify those particles analyzed. 


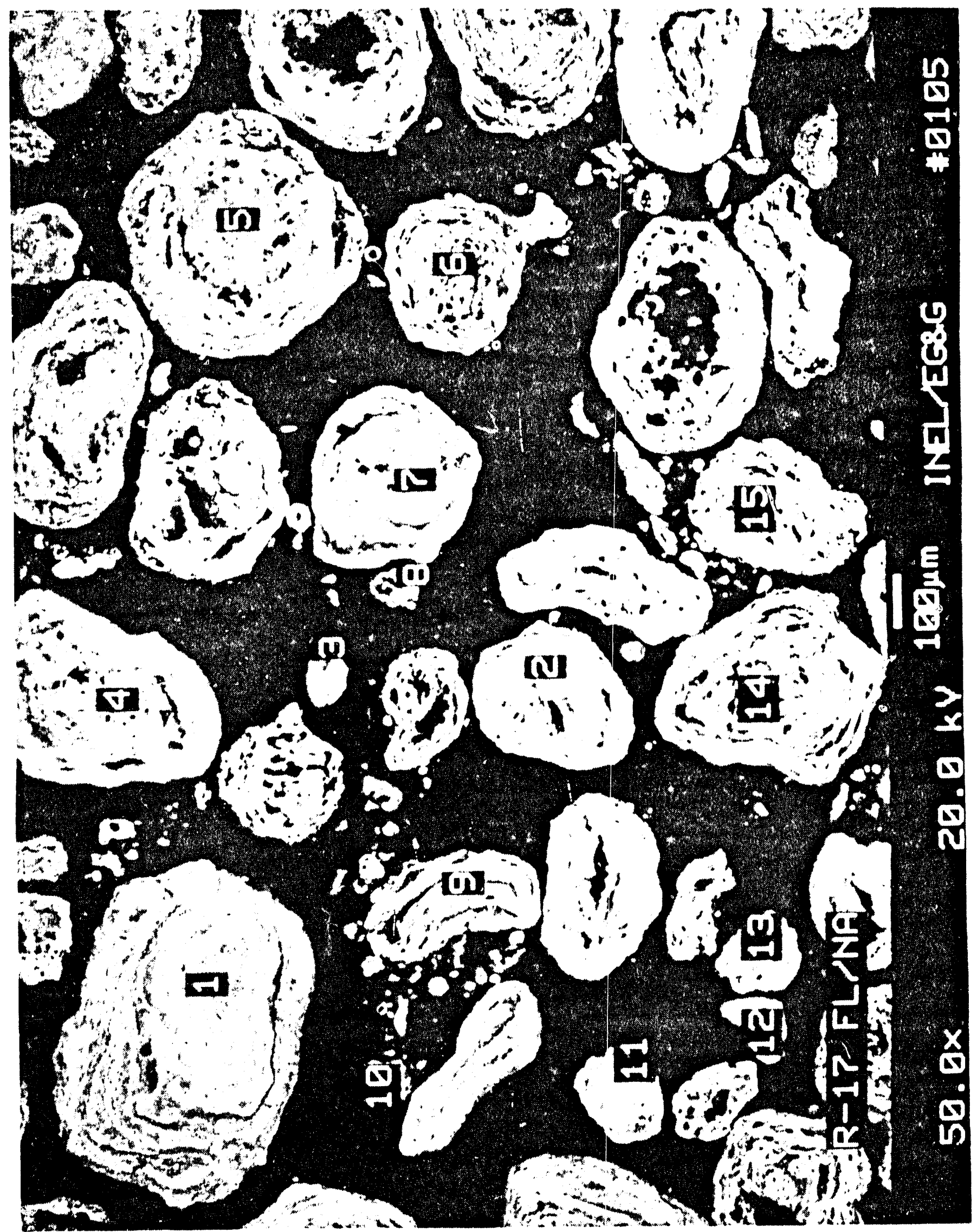


Table VI

SEM Data

Weight Percent Elements in Small Particle size

\begin{tabular}{|c|c|c|c|c|c|c|c|}
\hline \multirow[t]{2}{*}{ Element } & \multicolumn{7}{|c|}{ Particle Number } \\
\hline & 3 & 8 & 10 & 11 & 12 & 13 & $\begin{array}{c}\text { Average } \\
\text { Wto }\end{array}$ \\
\hline 0 & 31.64 & 26.24 & 32.24 & 23.92 & 27.60 & 28.82 & $\begin{array}{r}28.41 \\
+\quad 3.19 \\
\end{array}$ \\
\hline $\mathbf{F}$ & 25.21 & 32.27 & 22.74 & 26.36 & 26.92 & 24.59 & $\begin{array}{r}26.35 \\
\pm \quad 3.25 \\
\end{array}$ \\
\hline $\mathrm{Na}$ & 1.59 & 0.97 & 1.17 & 0.34 & 0.14 & 0.59 & $\begin{array}{r}0.80 \\
+\quad 0.54 \\
\end{array}$ \\
\hline Al & 5.14 & 3.67 & 4.90 & 5.69 & 6.06 & 6.09 & $\begin{array}{r}5.26 \\
+\quad 0.91 \\
\end{array}$ \\
\hline $\mathbf{S}$ & 1.34 & 0.45 & 0.52 & 0.37 & 0.46 & 0.50 & $\begin{array}{r}0.61 \\
+\quad 0.36 \\
\end{array}$ \\
\hline $\mathbf{K}$ & * & 0.26 & * & * & * & * & $\begin{array}{r}0.043 \\
\pm \quad 0.11 \\
\end{array}$ \\
\hline $\mathrm{Ca}$ & 22.04 & 29.00 & 21.03 & 25.65 & 25.95 & 24.00 & $\begin{array}{r}24.61 \\
+\quad 2.90 \\
\end{array}$ \\
\hline $\mathrm{Cr}$ & 1.28 & * & 1.25 & 0.17 & 0.16 & 0.28 & $\begin{array}{r}0.52 \\
+\quad 0.58 \\
\end{array}$ \\
\hline Mn & * & * & * & 0.13 & 0.16 & 0.10 & $\begin{array}{r}0.065 \\
\pm \quad 0.074 \\
\end{array}$ \\
\hline $\mathrm{Zr}$ & 13.56 & 9.66 & 12.47 & 14.49 & 14.15 & 15.10 & $\begin{array}{r}13.24 \\
\pm \quad 1.97 \\
\end{array}$ \\
\hline $\mathrm{cd}$ & 5.00 & 3.19 & 4.24 & 5.00 & 5.21 & 4.97 & $\begin{array}{r}4.60 \\
\pm \quad 0.77\end{array}$ \\
\hline
\end{tabular}

1 The raw data are tabulated in Appendix $D$.

2 Precision of each measured weight percent value is about 2\%: uncertainty of each measured weight percent value is about $10 \%$.

* None Detected 
Table VII

SEM Data

Weight Percent Elements in Medium Particle size

\begin{tabular}{|c|c|c|c|c|c|c|}
\hline \multirow[t]{2}{*}{ Element } & \multicolumn{6}{|c|}{ Particle Number } \\
\hline & 2 & 6 & 7 & 9 & 15 & $\begin{array}{c}\text { Average } \\
\text { wt: }\end{array}$ \\
\hline 0 & 30.51 & 30.38 & 29.22 & 30.84 & 29.66 & $\begin{array}{r}30.12 \\
\pm \quad 0.66 \\
\end{array}$ \\
\hline $\mathbf{F}$ & 27.40 & 25.11 & 25.89 & 27.53 & 24.58 & $\begin{array}{r}26.10 \\
\pm \quad 1.33 \\
\end{array}$ \\
\hline $\mathrm{Na}$ & 0.55 & 1.05 & 0.32 & 1.15 & 0.60 & $\begin{array}{r}0.73 \\
+\quad 0.35 \\
\end{array}$ \\
\hline Al & 5.23 & 4.98 & 5.30 & 5.47 & 5.41 & $\begin{array}{r}5.28 \\
+\quad 0.19 \\
\end{array}$ \\
\hline $\mathbf{S}$ & 0.50 & 0.26 & 0.31 & 0.42 & 0.57 & $\begin{array}{r}0.41 \\
\pm \quad 0.13 \\
\end{array}$ \\
\hline $\mathbf{K}$ & 0.12 & 0.17 & * & 0.17 & 0.09 & $\begin{array}{r}0.11 \\
\pm \quad 0.07 \\
\end{array}$ \\
\hline $\mathrm{Ca}$ & 24.90 & 22.03 & 25.16 & 25.04 & 24.88 & $\begin{array}{r}24.40 \\
\pm \quad 1.33 \\
\end{array}$ \\
\hline $\mathrm{Cr}$ & 0.16 & 0.46 & 0.72 & 0.13 & 0.09 & $\begin{array}{r}0.31 \\
+\quad 0.27 \\
\end{array}$ \\
\hline Mn & * & * & 0.09 & $\star$ & 0.05 & $\begin{array}{r}0.028 \\
+\quad 0.041 \\
\end{array}$ \\
\hline $\mathrm{Zr}$ & 11.79 & 12.41 & 12.23 & 13.19 & 13.72 & $\begin{array}{r}12.67 \\
\pm \quad 0.77 \\
\end{array}$ \\
\hline $\mathrm{Cd}$ & 5.31 & 3.13 & 5.04 & 5.07 & 5.17 & $\begin{array}{r}4.74 \\
+\quad 0.91 \\
\end{array}$ \\
\hline
\end{tabular}

1 The raw data are tabulated in Appendix $\mathrm{E}$.

2 Precision of each measured wejght percent value is about 2\%; uncertainty of each measured weight percent value is about 10\%.

* None Detected 
Table VIII

SEM Data

Weight Percent Elements in Large Particle size

\begin{tabular}{|c|c|c|c|c|c|}
\hline \multirow[t]{2}{*}{ Element } & \multicolumn{5}{|c|}{ Particle Number } \\
\hline & 1 & 4 & 5 & 14 & $\begin{array}{c}\text { Average } \\
\text { Wto }\end{array}$ \\
\hline 0 & 28.96 & 30.59 & 25.84 & 30.37 & $\begin{array}{r}28.94 \\
\pm \quad 2.19 \\
\end{array}$ \\
\hline $\mathbf{F}$ & 28.44 & 26.00 & 26.63 & 28.56 & $\begin{array}{r}27.41 \\
\pm \quad 1.29 \\
\end{array}$ \\
\hline $\mathrm{Na}$ & 1.67 & 0.62 & 0.21 & 0.65 & $\begin{array}{r}0.79 \\
\pm \quad 0.62 \\
\end{array}$ \\
\hline Al & 6.09 & 6.27 & 4.97 & 5.59 & $\begin{array}{r}5.73 \\
\pm \quad 0.58 \\
\end{array}$ \\
\hline $\mathbf{s}$ & 0.69 & 0.46 & 0.41 & 0.25 & $\begin{array}{r}0.45 \\
+\quad 0.18 \\
\end{array}$ \\
\hline $\mathbf{K}$ & 0.11 & * & 0.14 & 0.23 & $\begin{array}{l}0.12 \\
+\quad 0.095 \\
\end{array}$ \\
\hline $\mathrm{Ca}$ & 25.48 & 24.93 & 27.47 & 24.76 & $\begin{array}{r}25.66 \\
\pm \quad 1.25 \\
\end{array}$ \\
\hline $\mathrm{Cr}$ & 1.33 & 0.07 & 0.18 & 0.48 & $\begin{array}{r}0.52 \\
+\quad 0.57 \\
\end{array}$ \\
\hline Mn & 0.08 & 0.15 & 0.09 & * & $\begin{array}{r}0.080 \\
\pm \quad 0.062 \\
\end{array}$ \\
\hline $\mathrm{Zr}$ & 11.28 & 14.52 & 11.55 & 14.08 & $\begin{array}{r}12.86 \\
\pm \quad 1.68 \\
\end{array}$ \\
\hline$c d$ & 4.69 & 4.90 & 5.17 & 3.22 & $\begin{array}{r}4.50 \\
\pm \quad 0.87 \\
\end{array}$ \\
\hline
\end{tabular}

1 The raw data are tabulated in Appendix F.

2 Precision of each measured weight percent value is about 2\%; uncertainty of each measured weight percent vaj ie is about $10 \%$.

* None Detected 
The analyzed particles were grouped into three categories by their relative sizes: large, medium and small. Data from the analysis of each size particle was collated according to particle 81ze. Tables VI-VIII list the results from the analyses of amall, medium, and large particles, respectively. The raw SEM data used to generate Tables VI through VIII are found in Appendices $D$ through $F$, respectively. As these results show, there is no correlation between the composition and size of these particles. Good compositional agreement for most elements is found between the SEMS results and the results obtalned by other analytical techniques. Fluoride and sodium are exceptions, showing disagreement.

$x$-Ray mapping was also done on particles 1,2 , and 3 . This mapping shows the distribution of the major elements throughout the individual particle. These maps are shown in Figures 7-11. $x$-Ray mapping data shows fairly even distribution of $0, F, A l$, $\mathrm{Ca}, \mathrm{Zr}$, and Cd throughout the particles. Chromium in particle 3 is seen to be unevenly distributed with heavy concentrations at the center and edges of the particle. 


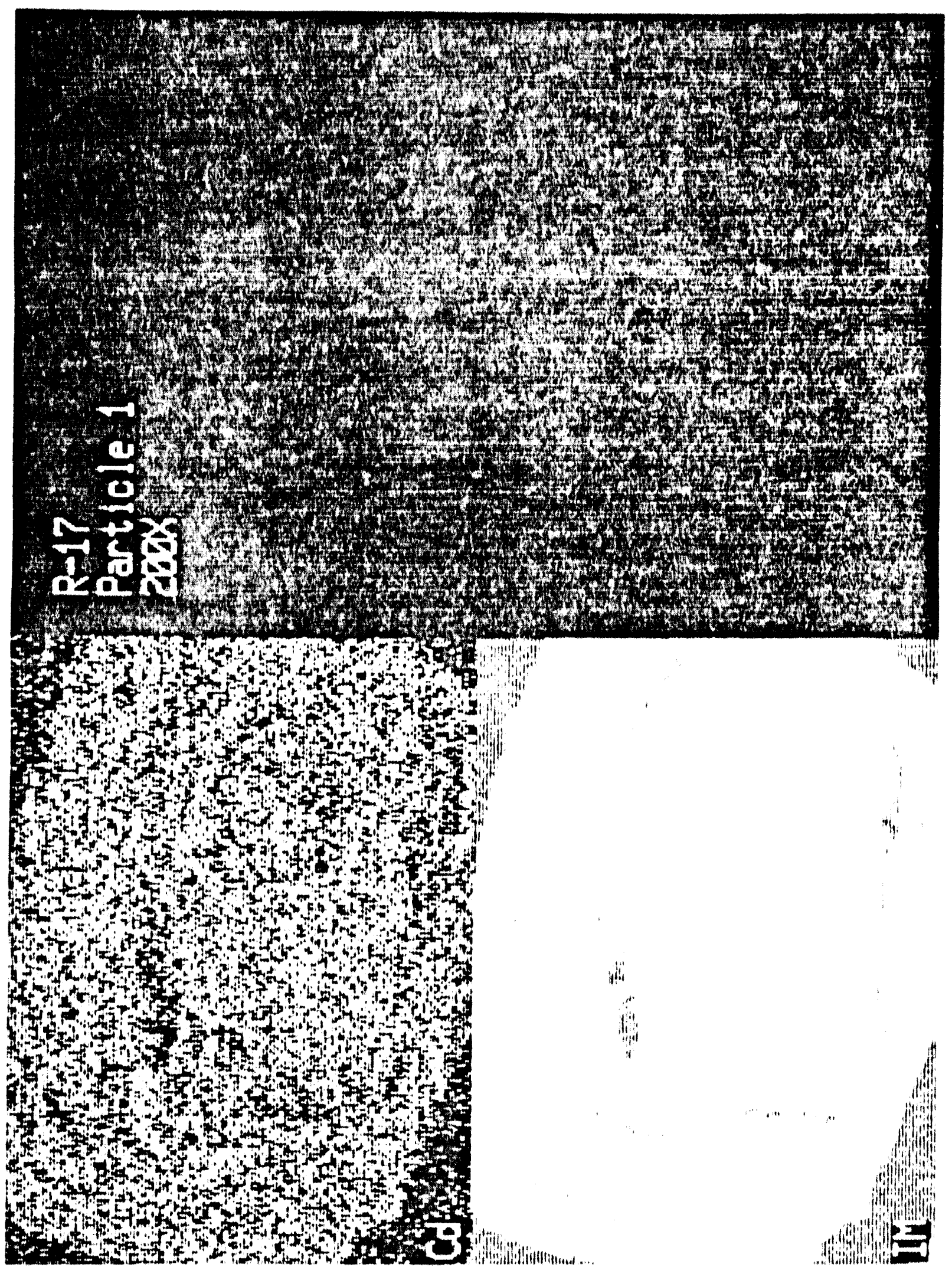




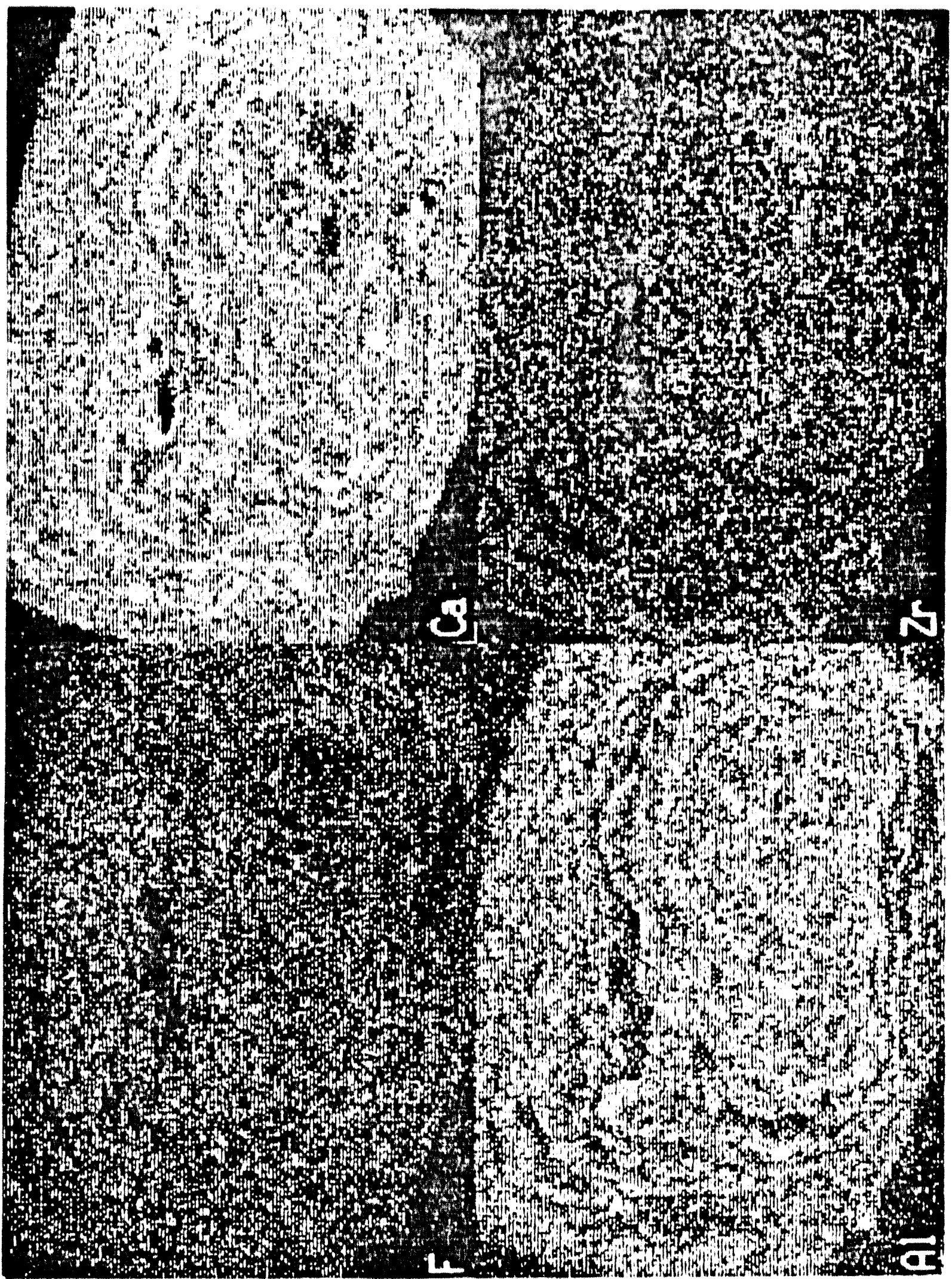




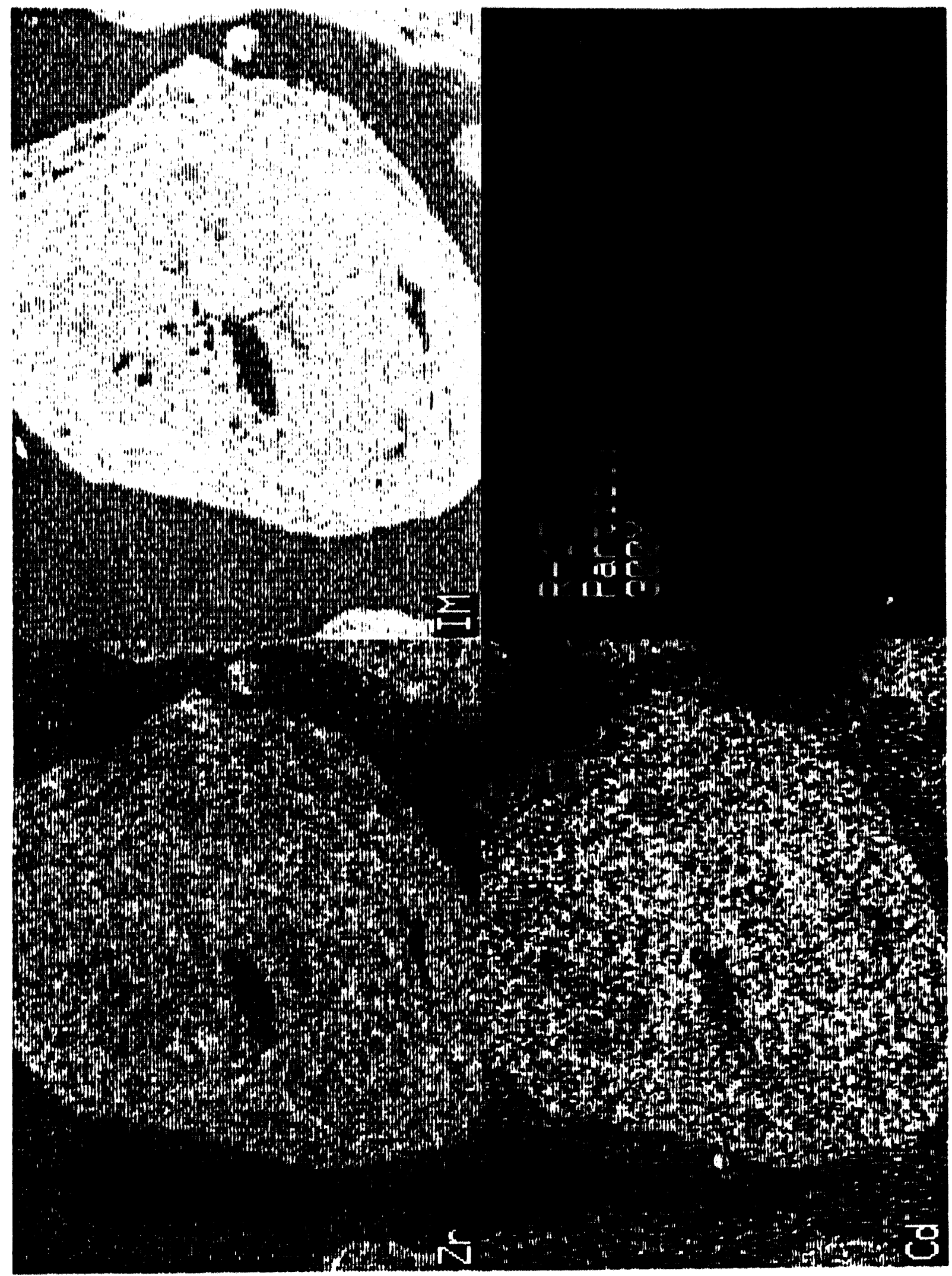




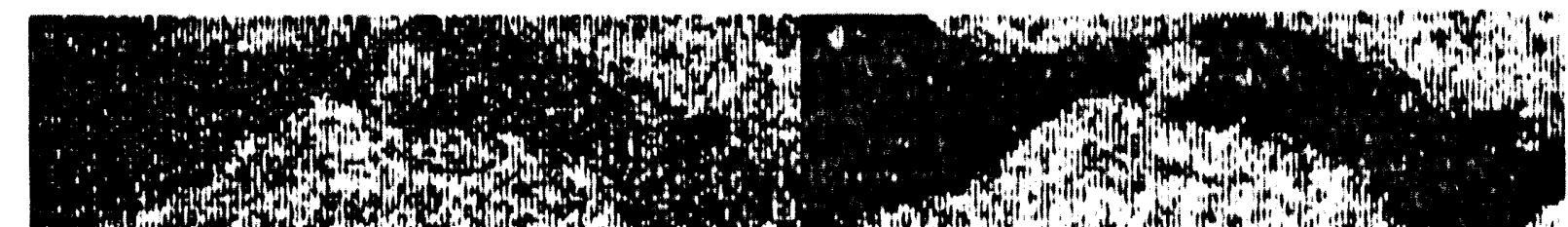

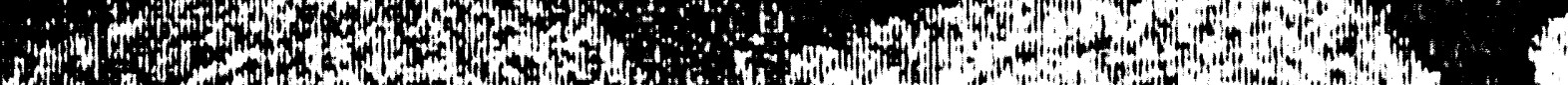

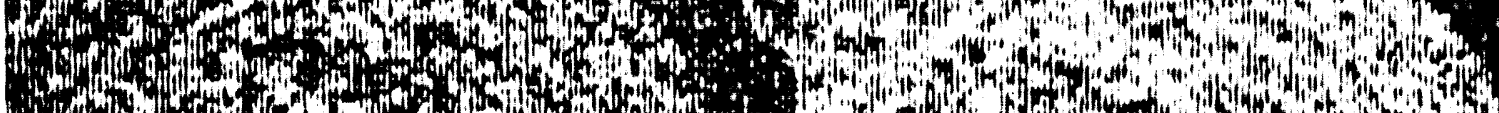

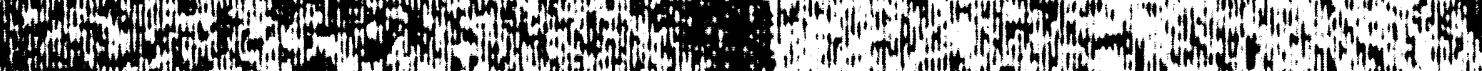

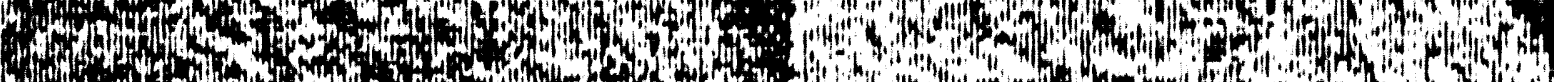

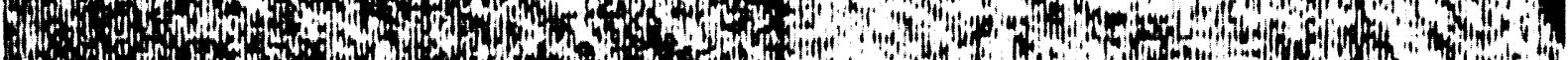
A $y_{1}$, do (B)

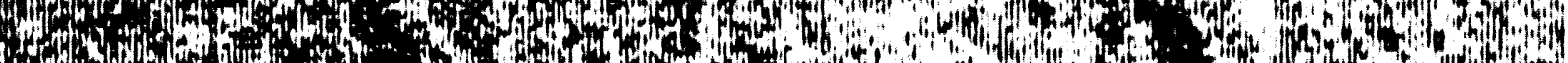

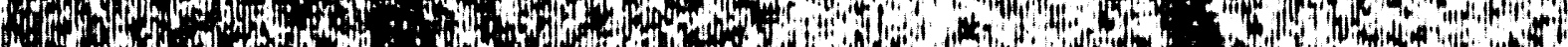

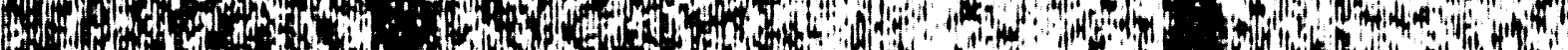

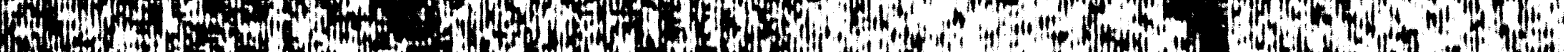

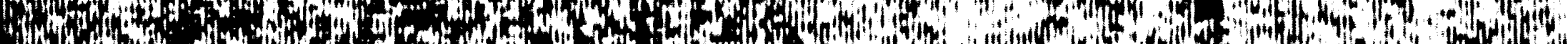

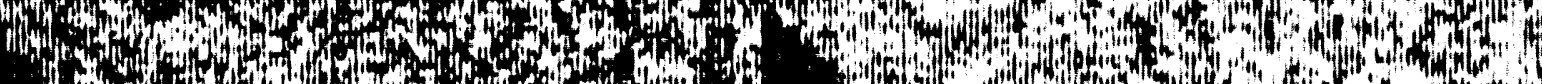

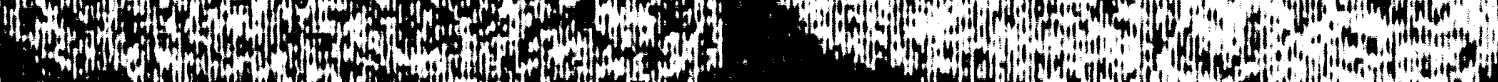
W.

(a)

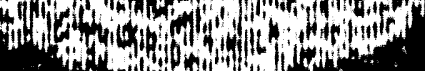

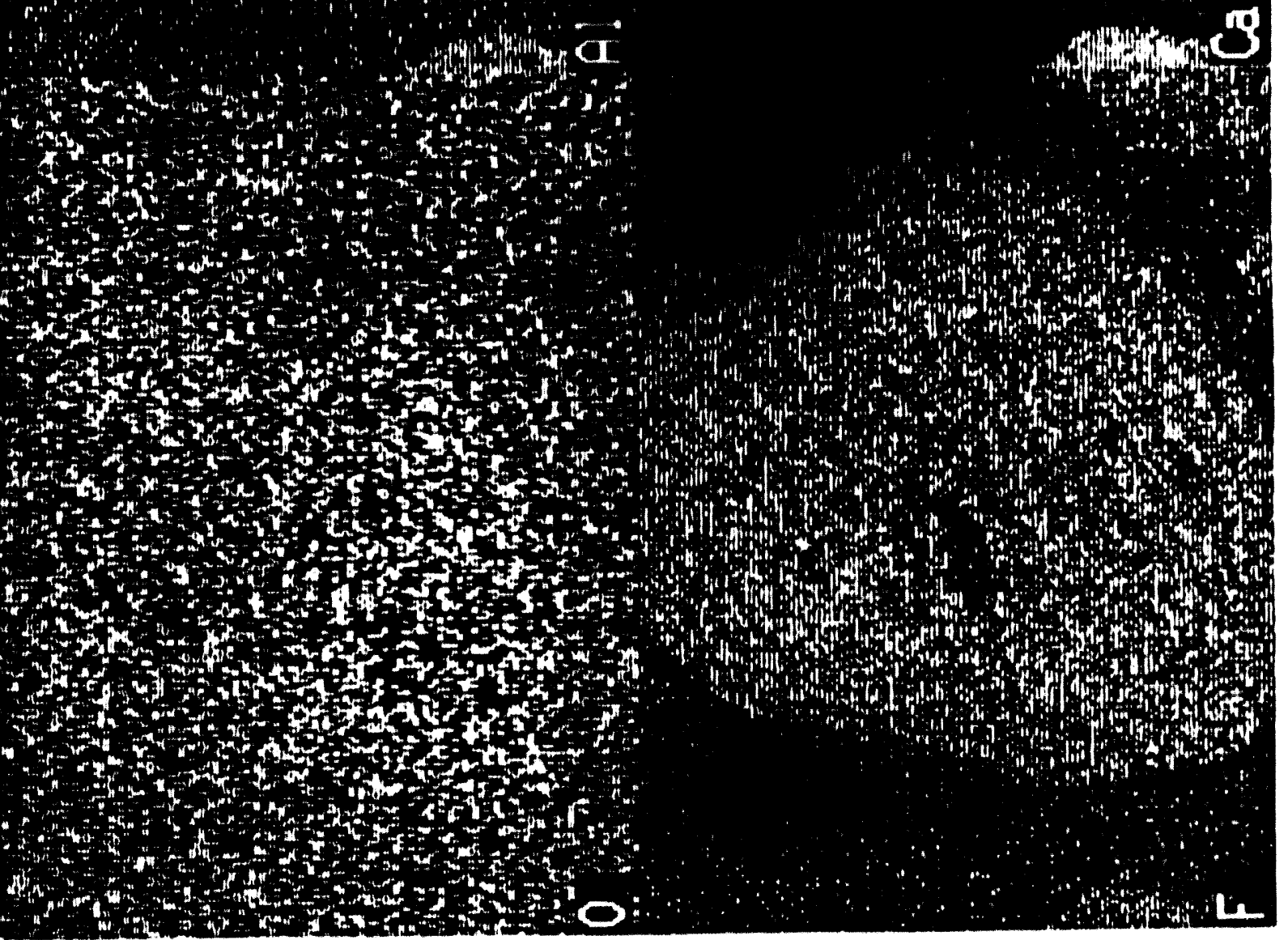




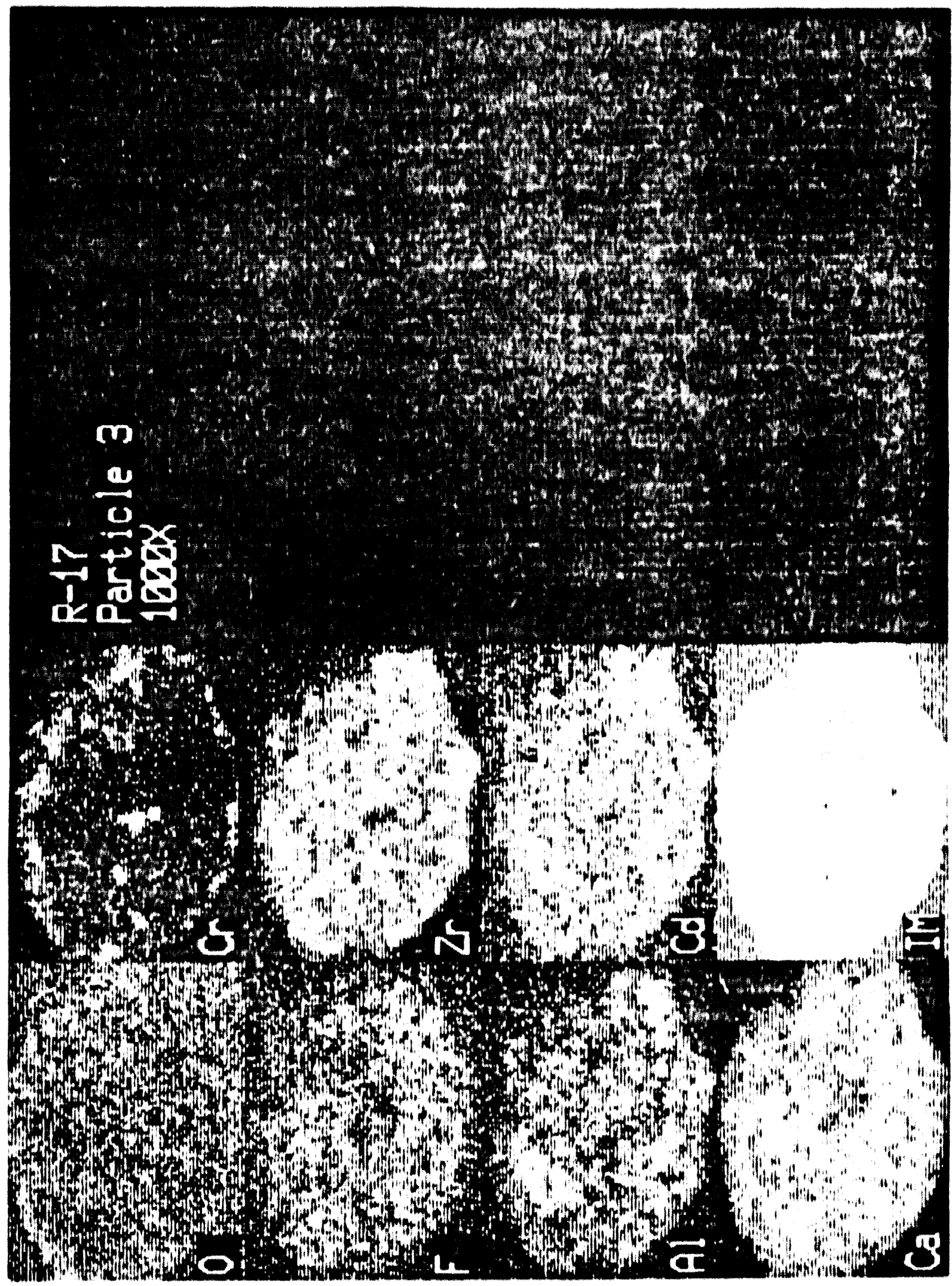




\section{IPO Data}

XPs analys is was performed to ldentify the chemlcal bonding of the metal atome present in the calcine particles. Figure 12 is the XPs data obtalned from an energy soan of the calcine. The $x-$ ax1. represente the energy required to ramove an electron from an atom in the sample, in electron volts (ov), the $y$-axis is a relative masure of the number of electrone ejected from the ample. Adjacent to each peak on the epectrum is a label that Inoludes the elemental eymbol followed by an energy level/eublevel designation for the electron that would be ajected Erom an atom of that element, at the glven binding energy. The epeciflc amount of energy required to dieplace an electron (Binding Energy) erom an atom is dependant on the chemical bonding of the atom. Because speciflc binding energies are aseoclated with compounds, not elemente, the chemical form of the elemente in a sample may be ldentifled by XPS analysis.

The calcine is very compllcated chemlcal matrixl subeequently, the upectrum exhibits broad energy peaks. These broad peaks make data interpretation very diffloult because of the large number of compounds assoclated with a narrow range of binding energles. small ohifte in binding energy may also be caused by a large number of different elements and a rough-surfaced sample. As both of these attributes are exhlblted by calcine, this adds even 
Fiqure 12

Esch scan

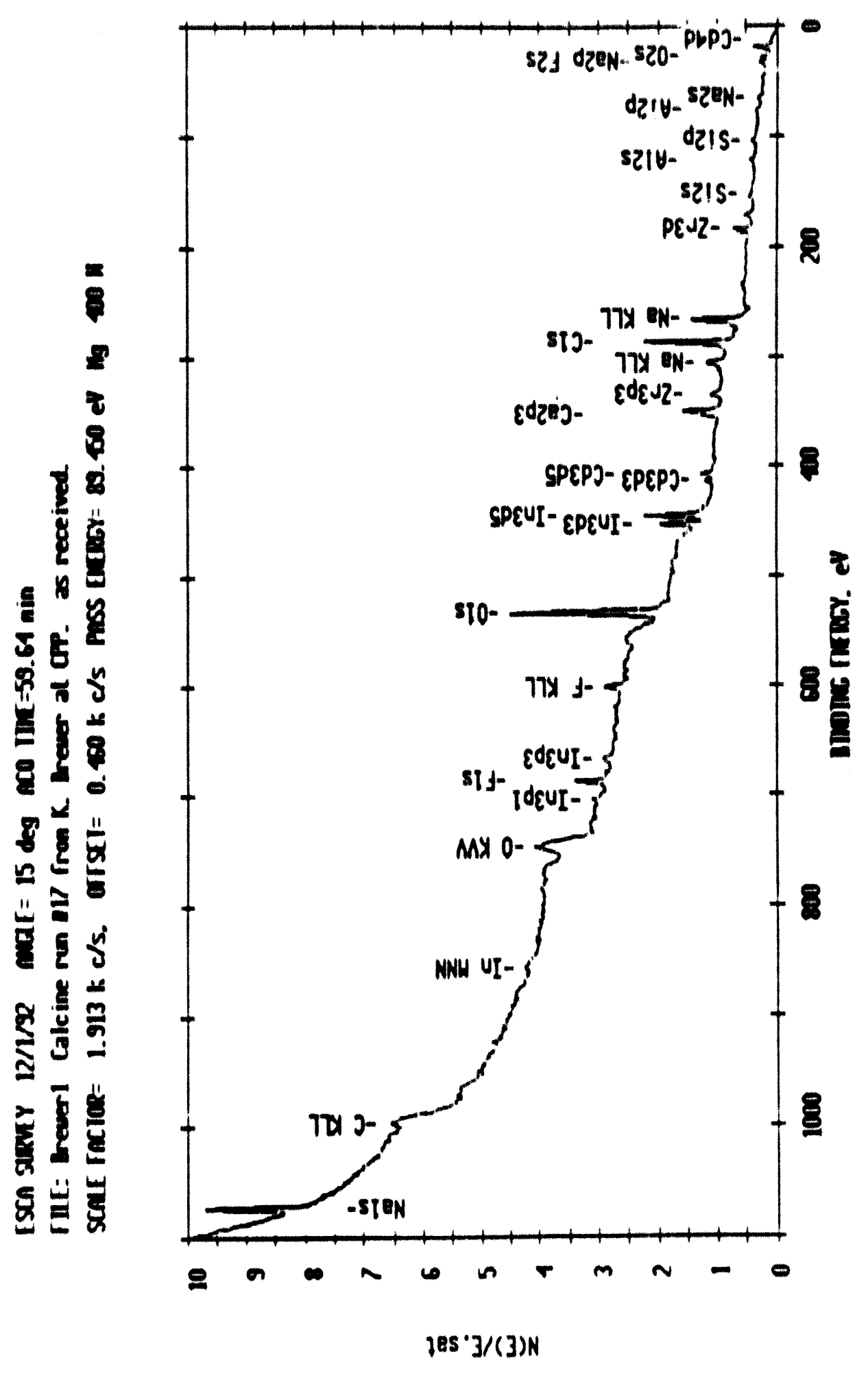


greater uncertainty to the conclusions that may be drawn from these analytical results.

As seen on Figure 12, elemente found in the calcine are: carbon, oxygen, tluoride, cadmium, calclum, zirconium, sodium, chloride, -11lcon, and aluminum. Some elemente have more than one peak, suggeuting that these elomente are present in multiple chemical environments. Table IX shows the atomic percent of these element. in the calcine.

2able Ix

Atomic Concentrations of Elements Found in calcine

\begin{tabular}{|c|c|c|}
\hline Element & $\begin{array}{c}\text { Concentration } \\
\text { Atomic }\end{array}$ & $\begin{array}{c}\text { Concentration } \\
\text { Wt }\end{array}$ \\
\hline C & 40.08 & 26.46 \\
\hline 0 & 37.30 & 32.82 \\
\hline $\mathrm{Na}$ & 7.55 & 9.54 \\
\hline F & 3.92 & 4.11 \\
\hline Cd & 0.62 & 3.84 \\
\hline 2 S & 1.33 & 6.66 \\
\hline S1 & 2.07 & 3.19 \\
\hline Al & 3.23 & 4.80 \\
\hline Ca & 3.91 & 8.61 \\
\hline
\end{tabular}

The weight percents in Table IX differ significantly from the results of the ICP analyses. The discrepancy between these two methods can be attributed to the carbon and oxygen found by XPS, that was not detected by ICP because the technique cannot be used 
to detact oxygen and carbon. It is not known if the carbon and oxygen results are representative of the samples or are artifacts of surface contamination on the calcine. Electron sputtering was not performed prior to XPS analysis to burn off the top layer of the calcine. Electron sputtering the surface of the calcine prior to analys may elucidate he answers to these questions, and will be performed during future analyses.

Appendix $G$ contains the raw data generated from the XPS analysis. Each element found will have two binding energy graphs, one graph was generated from multiplexing the data and the other is a gaussian fit. Multiplexing the data allows for easier interpretation of the data by accounting for all the possible interferences that might cause a shift in binding energy. The gaussian fit is done to check the rellability of multiplexing the data. A curve fit summary accompanies the curve fit graph of the peak. Following the curve fit summary is a list of possible compounds that include the element; these 11sts were produced by removing from the curve fit listing phases which were highly unlikely based on chemical knowledge and process conditions. The curve fit lists were further reduced by comparing the elements on this list to those found by ICP analysis (Table II) and the SEM (Tables III-VIII). Table $X$ summarizes the data from XPS analysis. The listing includes a large number of siliclous phases that are included even though it isn't very likely that large amounts of silicon were present in the calciner feed. 
Table $\mathrm{x}$

Compounds Found By XPS Analysis That Are Most Likely To Be In Run 17 Calcine

\begin{tabular}{|c|c|}
\hline Element & Compound \\
\hline $\mathbf{F}$ & $\mathrm{K}_{2} \mathrm{SiF}_{6}, \mathrm{Na}_{2} \mathrm{SiF}_{6}, \mathrm{CaF}_{2}$ " \\
\hline $\mathrm{Na}$ & 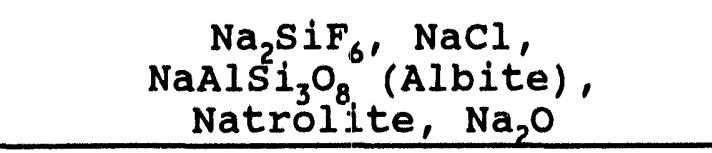 \\
\hline $\mathrm{Cd}$ & $\mathrm{CdS}, \mathrm{CdO}, \mathrm{CdF}_{2}$ \\
\hline $\mathrm{zr}$ & $\mathrm{ZrF}_{6}, \quad \mathrm{~K}_{2} \mathrm{ZrF}_{6,} \mathrm{ZrO}_{2}$ \\
\hline si & $\begin{array}{c}\mathrm{Al}_{2} \mathrm{SiO}_{5} \text { (Kyanite), } \\
\mathrm{NaAlsi}_{3} \text { (Albite), } \\
\text { Alsio }_{5} \text { (Siliimanite), } \\
\text { Natrolite }\end{array}$ \\
\hline Al & $\begin{aligned} & \mathrm{Al}_{2} \mathrm{O}_{3}, \text { NaAlsi } \mathrm{O}_{3} \mathrm{O}_{8} \text { (Albite), } \\
& \mathrm{Al}_{2} \mathrm{SiO}_{5} \text { (Kyanite), Bentonite }\end{aligned}$ \\
\hline $\mathrm{Ca}$ & $\begin{array}{c}\mathrm{Ca}\left(\mathrm{NO}_{3}\right)_{2}, \mathrm{CaSO}_{4}, \mathrm{CaF}_{2}, \mathrm{CaO}, \\
\mathrm{CaS}^{\prime} \mathrm{CaCrO}_{4}, \mathrm{CaCl}_{2}\end{array}$ \\
\hline C & $\begin{array}{c}\text { Probably an Analytical } \\
\text { Artifact }\end{array}$ \\
\hline 0 & $\begin{aligned} \mathrm{Na}_{2} \mathrm{SiO}, & \mathrm{FeSO}_{4}, \mathrm{Cr}_{2} \mathrm{SO}_{4 \prime} \mathrm{CaSO}_{4} \\
\mathrm{Al}_{2} \mathrm{SiO}_{5}, & \mathrm{SiO}_{2}, \mathrm{KNO}_{3}, \mathrm{CaNO}_{3}, \mathrm{CO}\end{aligned}$ \\
\hline
\end{tabular}

* Major constituent

Minor consituents of the calcine were not detected, therefore, no XPS data is available to deduce their composition. 


\section{$F \star A * C * T$ Program Data}

In an attempt to further reduce the number of possible compounds formed during the calcination process, the Facility for the Analysis of Chemical Thermodynamics $(F * A * C * T)$ EQUILIB code 3 was used to determine which compounds would form at equilibrium conditions in the calciner operating conditions of 1 atm and $500^{\circ} \mathrm{C}$. Calciner feed concentrations listed in Table I were used as input for the calculations into the program. In addition, fuel, oxygen and fluidizing air concentrations were also added. Chemically stated, the reactants going into the calciner were:

$$
\begin{aligned}
& 55.405 \mathrm{M} \mathrm{H}_{2} \mathrm{O}+4.558 \mathrm{MNO} \mathrm{NO}_{3}^{-}+0.01 \mathrm{MCl}+0.046 \mathrm{MS}+0.092 \mathrm{M} \mathrm{O} \\
& 1.648 \mathrm{MH}^{+}+0.081 \mathrm{MCC^{+2 }}+0.338 \mathrm{M} \mathrm{Na}+1.709 \mathrm{MF}^{-}+1.055 \mathrm{M} \mathrm{Ca} \mathrm{Ca}^{+2} \\
& 0.14 M B^{+3}+0.393 M A I^{+3}+0.233 M Z I^{+4}+13.1 M O_{2}+52.4 M N_{2}+ \\
& 2.1 M C^{-4}+4.2 M H^{+}=? ? ?
\end{aligned}
$$

From a large list of possible products, the EQUILIB minimizes the Gibbs free energy of the system and predicts the equilibrium state of the chemical system. Table XI list the solid products and moles of each solid predicted from calculations using the composition shown in Eq. 1. 
Table XI

Products Resulting From $F * A * C * T$ Program

\begin{tabular}{|c|c|}
\hline Product & Moles \\
\hline $\mathrm{CaF}_{2}$ & 0.845 \\
\hline $\mathrm{ZrO}_{2}$ & 0.233 \\
\hline $\mathrm{NaAlO}_{2}$ & 0.218 \\
\hline$(\mathrm{CaO})\left(\mathrm{Al}_{2} \mathrm{O}_{3}\right)$ & 0.081 \\
\hline$(\mathrm{CaO})_{3}\left(\mathrm{~B}_{2} \mathrm{O}_{3}\right)$ & 0.07 \\
\hline $\mathrm{Na}_{2} \mathrm{SO}_{4}$ & 0.046 \\
\hline $\mathrm{NaF}$ & 0.018 \\
\hline $\mathrm{NaCl}$ & 0.01 \\
\hline $\mathrm{Al}_{2} \mathrm{O}_{3}$ & 0.063 \\
\hline
\end{tabular}

These results, computed assuming that no amorphous phases were formed, are in agreement with the results that would be expected. Calcium fluoride is the most thermodynamically stable fluoridecontaining solid to be formed by the metals listed in rable XI, 4,c and as expected, $\mathrm{CaF}_{2}$ is predicted to be the most abundant fluoride-containing crystalline phase. The relative stabilities of these crystalline phases also show $\mathrm{NaF}(s)$ to be more stable than the fluorides of $\mathrm{Al}, \mathrm{Zr}$, and $\mathrm{Cd}$; the results predicted $\mathrm{NaF}(s)$ as the other, albeit minor, fluoride-containing

c The standard Gibbs free energies of formation, from the constituent elements, for the metal-fluorides tabulated below are in $\mathrm{kJ} / \mathrm{gram}-\mathrm{atom}$ of fluoride at $800 \mathrm{~K}$ : $\mathrm{CaF}_{2},-544.67 \mathrm{~kJ}$; $\mathrm{ZrF}_{4},-411.45 \mathrm{~kJ} ; \quad \mathrm{AlF}_{3},-433.64 \mathrm{~kJ} ; \mathrm{NaF},-491.96 \mathrm{~kJ} ; \quad$ and $\mathrm{CdF}_{2},-282.10 \mathrm{~kJ}$.

These data were computed from values in endnote 4 in the References section of the main body of this work. 
crystalline phase. The oxides of zirconium, aluminum, and calcium are also quite stabled and, as expected, $2 \mathrm{rO}_{2}$ and $\mathrm{Al}_{2} \mathrm{O}_{3}$ are predicted. No CaO was predicted because the fluoride phase consumed most of the calcium and the remainder of the $\mathrm{Ca}$ is consumed by the formation of the $\mathrm{Ca}_{3} \mathrm{~B}_{2} \mathrm{O}_{6}$ phase; other mixed metal phases predicted are $\mathrm{NaAlO}_{2}$ and $\mathrm{CdAl}_{2} \mathrm{O}_{4} \cdot$

From the results tabulated in Table XI, it may be concluded that some of the important chemical reactions occurring during calcination may be:

$$
\begin{gathered}
\mathrm{Ca}^{+2}+2 \mathrm{~F}^{-}=\mathrm{CaF}_{2} \\
\mathrm{Zr}+2 \mathrm{O}^{-2}=\mathrm{ZrO}_{2} \\
\mathrm{Na}^{+}+\mathrm{Al}+3+2 \mathrm{O}^{-2}=\mathrm{NaAlO}_{2}
\end{gathered}
$$

Results from EQUILIB in many cases are in good agreement with the XRD analysis. XRD did identify $\mathrm{CaF}_{2}$ and $\mathrm{ZrO}_{2}$ as major crystalline structures in the calcine; however, the XRD analysis also found $\mathrm{NaNO}_{3}$, which was not a predicted during the computational study. This discrepancy can be explained by addressing the kinetics of calcination chemistry.

d The standard Gibbs free energies of formation, from the constituent elements, for the metal-oxides below are tabulated in $\mathrm{kJ} / \mathrm{gram}-\mathrm{atom}$ of oxygen at $800 \mathrm{~K}$ : $\mathrm{CaO},-551.59 \mathrm{~kJ} ; \mathrm{ZrO}_{2},-472.36 \mathrm{~kJ}$; $\mathrm{Al}_{2} \mathrm{O}_{3},-474.96 \mathrm{~kJ} ; \mathrm{Na}_{2} \mathrm{O},-308.12 \mathrm{~kJ} ;$ and $\mathrm{CdO},-178.40 \mathrm{~kJ}$.

These data were computed from values in endnote 4 in the References section of the main body of this work. 
The calcination process is most likely a dynamic, kineticallycontrolled process. As the water in the feed evaporates, it is possible for nitrate to become trapped in the calcine particle. This could prevent the decomposition of alkali metal nitrates, even though $500^{\circ} \mathrm{C}$ is far above the normal decomposition temperatures of the nitrates of potassium and sodium, $334^{\circ} \mathrm{C}$ and $306^{\circ} \mathrm{C}$, respectively. ${ }^{4}$

The computational results are also in good agreement with the SEM data. Areas with high concentrations of calcium and fluoride were found, as well as areas with high concentrations of calcium, aluminum, zirconium, and oxygen; it is likely that these are areas of calcium fluoride and of oxides phases, respectively.

XPS results are not in complete agreement with the XRD and computational results. The most glaring difference is the carbon detected during the XPS analyses. Carbonaceous phases were not identified during the XRD analyses, and because carbon was not identified as an element present during the computational work, no carbonaceous phases were predicted. The XPS results do, however, suggest the presence of a great number of sodium and aluminum phases. It is possible that these phases, which are compositionally quite similar, may have similar binding energies. This would make it difficult to distinguish the various sodium and aluminum compounds from one another. 


\section{Conolueions}

The results of a variety of analyses, ICP, XRD, SEM, and XPS, and of equilibrium calculations on Run 17 pilot plant calcine have been performed in an attempt to characterize the physical and chemical nature of the calcine. The SEM results show that the calcine is inhomogeneous and multiphasic in chemical character. These results do suggest, however, that there is a correlation between gross composition and particle size, with compositional ranges for the major constituents of the calcine (F, Al, Ca, and Zr) deviating from 5 to 10 ; ranges of the minor constituents of the calcine can deviate up to $65 \%$.

Composition of the crystalline and amorphous phases of the calcine indicate that a large portion of the calcine is calcium fluoride, aluminum oxide, calcium oxide, and zirconium oxide. The computational results and XPS results indicate that most of the sodium is associated with the aluminum to form sodium aluminate. The SEM results also support this interpretation. Areas of pure aluminum oxide were not found; sodium was always detected with the aluminum, although there is no reason not to expect that some of this aluminum was present as $\mathrm{Al}_{2} \mathrm{O}_{3}$ and that some of the sodium present as $\mathrm{NaF}, \mathrm{NaCl}$, and $\mathrm{NaSO}_{4} \cdot \mathrm{Cadmium} \mathrm{is}$ most likely present as both Cdo and Cds, although it is not possible to quantitatively determine the amounts of these phases because of the matrix effects associated with the analytical techniques 
Additional analyses on Run 17 should be performed before quantitative concentrations of the compounds are reported. This may include microprobe analysis to determine boron concentrations and electron sputtering the calcine sample prior to XPS analysis. 


\section{Appona1x $\mathbf{A}$}

Point by Point SEM Data for Particle 1

A-1 


$$
30-N=1 V-199 \Xi 13113157
$$

Acceleratirig voltage

Eeam - sample lriciderice ariqle

Xray emergerice arigle

Xray - wiridow irielderice arigle
R17FLNA-1-1

Ev. $\mathrm{KeV}$

9x. de deques

35.0 degrees

Q. Degrea

\footnotetext{
QUANTITATIVE EDS RESULTS

(ZAF CORRECTIONS VIA MAGIC $V$ )
}

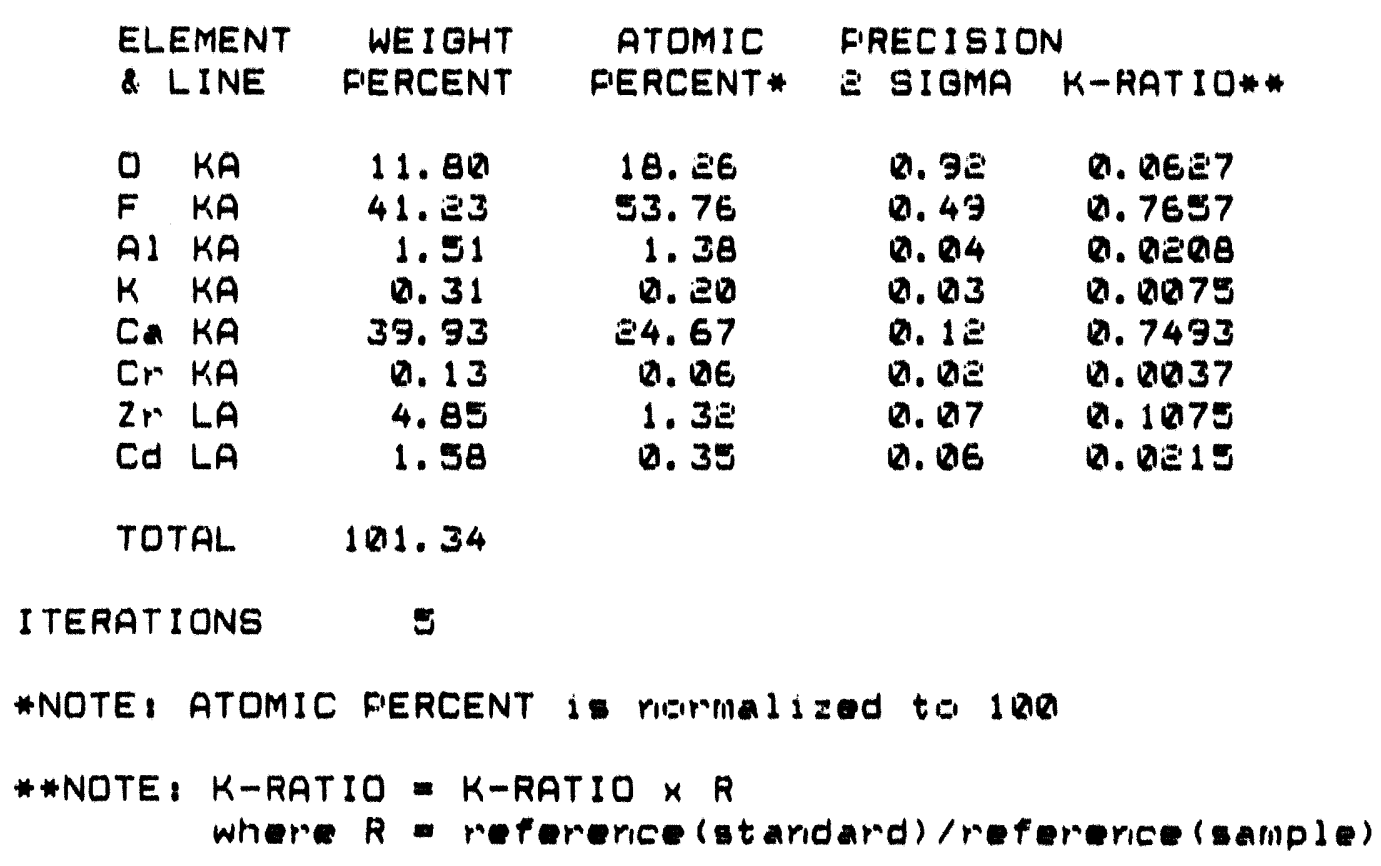




$$
\text { 30-NGV-199a } 13117100
$$

Acceleratirig valtage

Beali - sample iriciderice ariqle

Xray emerperice arigle

Xray - wiridis Iriciderice angle
R17FLNA-1-2

Ev. KeV

30. d degrees

35. deprees

Q. deqrees

QUANTITATIVE EDS RESULTS

(ZAF CORRECTIONS VIA MAQIC V)

ELEMENT WEIGHT ATOMIC FIRECISION
Q LINE FIERCENT FERCENT E $8 I$ IGA K-RATIO*

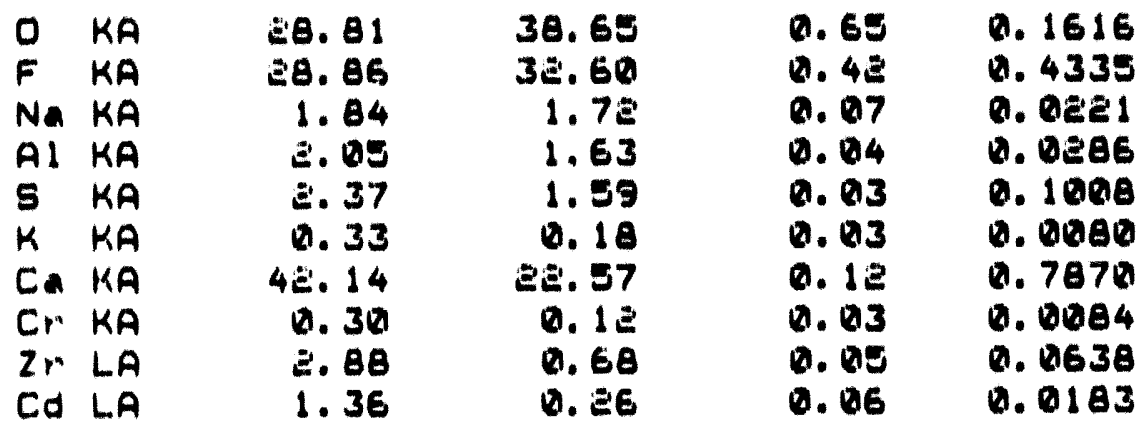

TOTAL 118.94

I TERATIONS

*NOTE, ATOMIC FERCENT is rismmalized ta jaa

* NOTE, K-RATIO = K-RATIO KR

where $R$ - refererice (staridard)/refererice (sample) 


$$
34-N i a r-199 a 13120134
$$

Acceleratirig voltape

Beam - sample iriciderice ariqle

Xray emerperice arigle

Xray - windsiw inciderice angle
H1 7FLNA-1-3

E. K KeV

3u. (1) deques

35. dearees

a. deqrees

$$
\begin{aligned}
& \text { OUANTITAT IVE EDS REBULTS } \\
& \text { (ZAF CORRECTIONS VIA MAQIC V) }
\end{aligned}
$$

\begin{tabular}{|c|c|c|c|c|c|}
\hline $\begin{array}{l}0 \\
F \\
\text { Ad } \\
K \\
C a \\
C r \\
N i \\
2 r \\
C d\end{array}$ & $\begin{array}{l}K A \\
K A \\
K A \\
K A \\
K A \\
K A \\
K A \\
L A\end{array}$ & $\begin{array}{r}30.30 \\
16.15 \\
13.50 \\
0.00 \\
10.55 \\
0.43 \\
0.16 \\
14.65 \\
19.05\end{array}$ & $\begin{array}{l}54.18 \\
19.20 \\
11.30 \\
0.00 \\
5.95 \\
0.19 \\
0.05 \\
6.10\end{array}$ & $\begin{array}{l}0.63 \\
0.3 \pm \\
0.09 \\
0.00 \\
0.07 \\
0.03 \\
0.03 \\
0.13\end{array}$ & $\begin{array}{l}0.8468 \\
0.2467 \\
0.1971 \\
0.0000 \\
0.1756 \\
0.0137 \\
0.0015 \\
0.5115 \\
0.1728\end{array}$ \\
\hline
\end{tabular}

ELEMENT WEIGHT ATOMIC FRECISION
LINE FERCENT FERCENT E EIOMA K-RATIO*

TOTAL $\quad 118.84$

ITERATIONS

-NOTE, ATOMIC FERCENT Is rismmalized tE laO

* NOTE, K-RATIO - K-RATIO K R

where $R$ - refererice (staridard)/reforerice (sample) 


$$
\text { 30-NGV-199a } 131261 \text { aै }
$$

Acceleratirig voltage

Beam - sample inciderice anqle

xray emerperice ariple

xray - windaw incidence anqle
A17FLNA-1-4

an. $\mathrm{KeV}$

ga. deqrees

35. degrees

a. deqrees

\section{QUANTITATIVE EDS RESULTS \\ (ZAF CORRECTIONS VIA MAQIC V)}

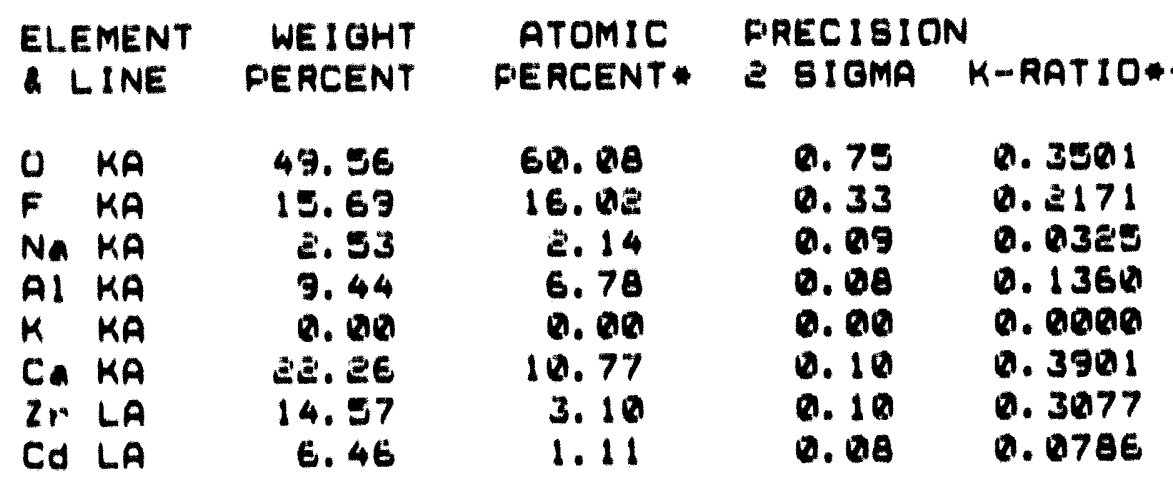

TOTAL IEQTI

ITERATIONS

-NOTE, ATOMIC FERCENT is rismmalized to 100

- NOTEI K-RATIO - K-RATIO NR

where $R$ = reforerice (staridard) /reference (sample) 


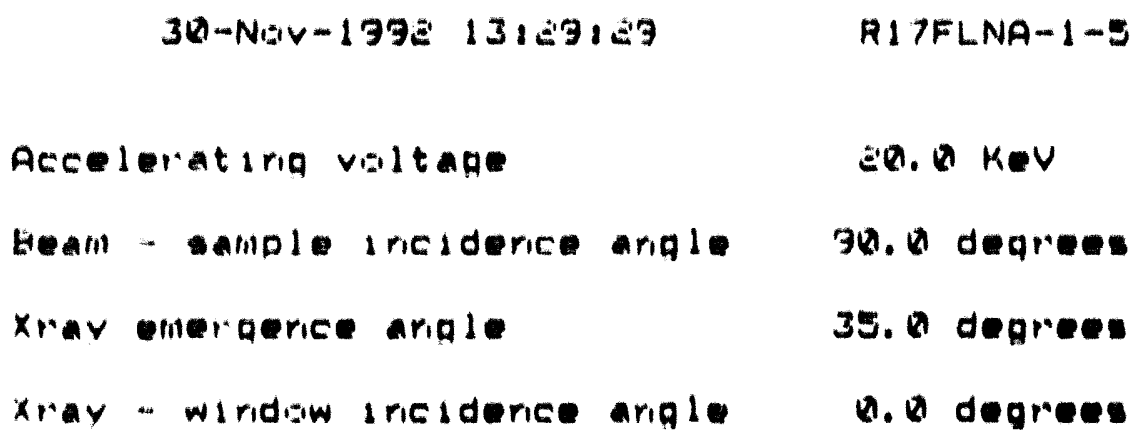

OUANTITATIVE EDS RESULTS
(ZAF CORRECTIONS VIA MACIC V)

ELEMENT WEIGHT ATOMIC FRECISION \& LINE FERCENT FERCENT a SIGMA K-RATIO**

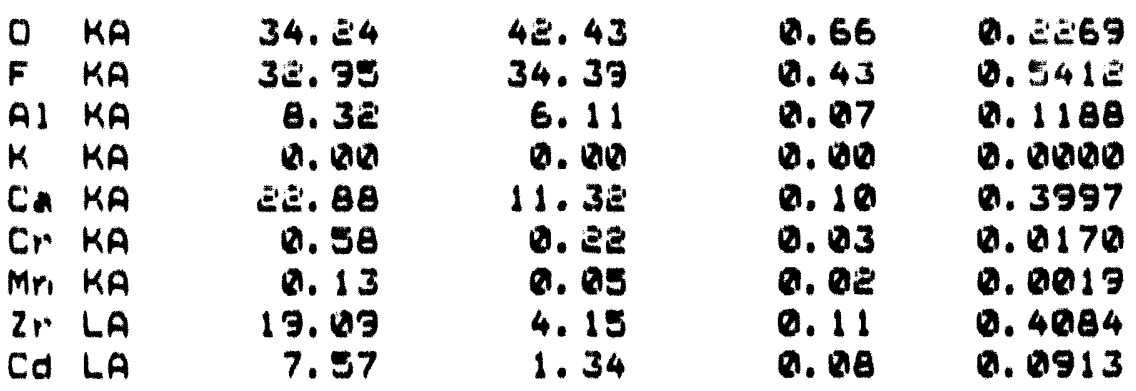

TOTAL IES.76

ITERATIONS 6

-NOTE, ATOMIC FERCENT is riermalized to log

- NOTEI K-RATIO = K-RATIO X R

where $R$ - reforerice (staridard)/refererice (sample) 


\section{Appendix $B$}

Point by Point 8EM Data For Particle 2

B-1 


$$
3(1-N:=199-19913: 37: 51
$$

Acceleratirg volt aue

Eeari - sample iriciderice arigle

Xray emergerice arigle

Xray - wiridaw iriciderice arigle
F1 7FLNAーEーー1

\author{
ED. QI KeV
}

301. deqrees

35. degrees

๑. Degrees

QUANTITATIVE EDS RESLILTS

(ZAF CORRECTIONS VIA MAIIC $V$ )

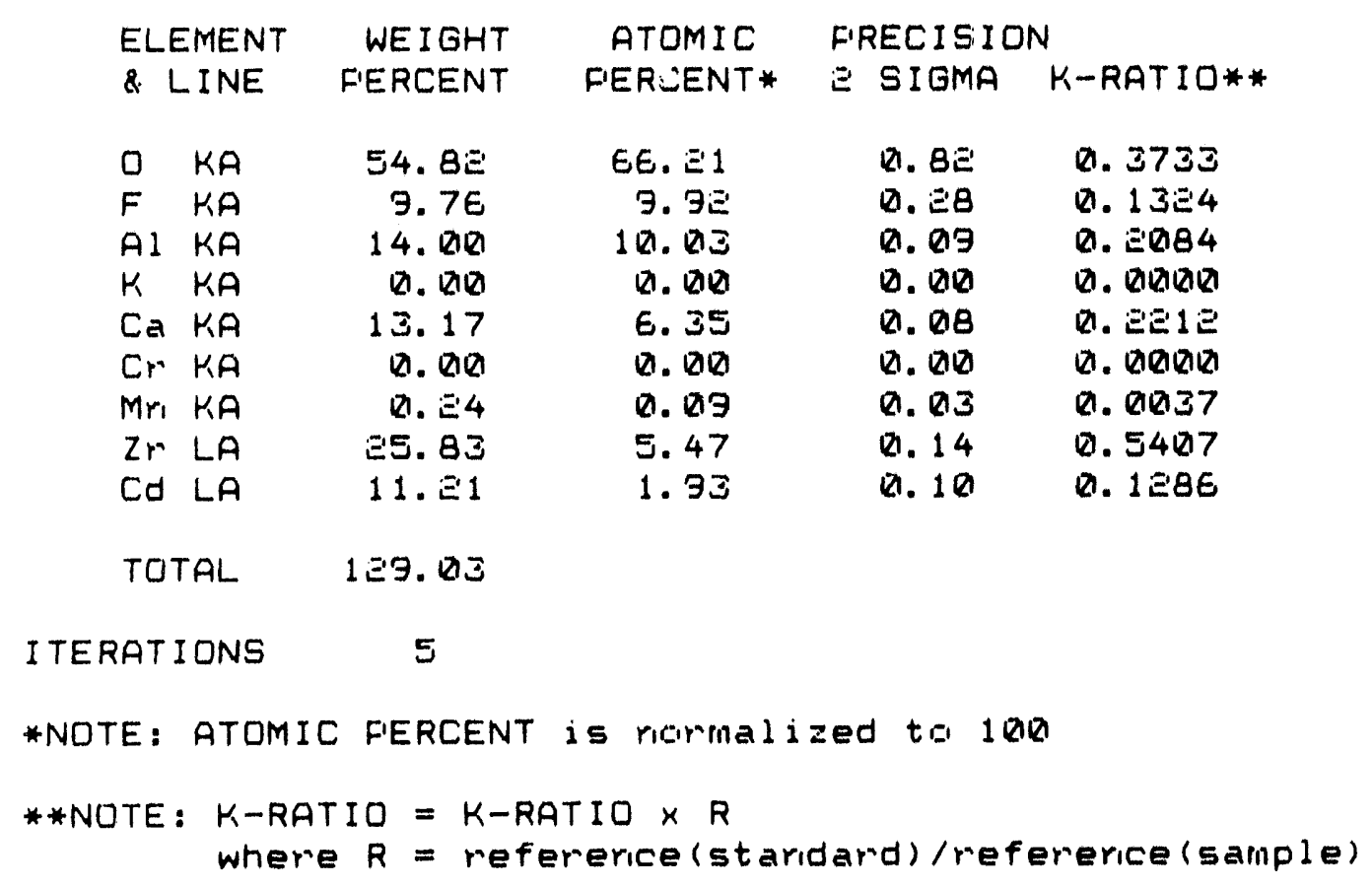




\begin{tabular}{|c|c|c|c|}
\hline Acce & leratirig voltage & & EQ. Q KeV \\
\hline Hean & - Sample iriciderice & arigle & 30. Q deqrees \\
\hline$x$ ray & emergerice arigle & & 35. degrees \\
\hline$x_{r} \sim a y$ & - wiridow iriciderice & $\arg 1 e$ & (1). (2) degrees \\
\hline
\end{tabular}

GUANTITATIVE EDS RESULTS

(ZAF CORRECTIONS VIA MAGIC V)

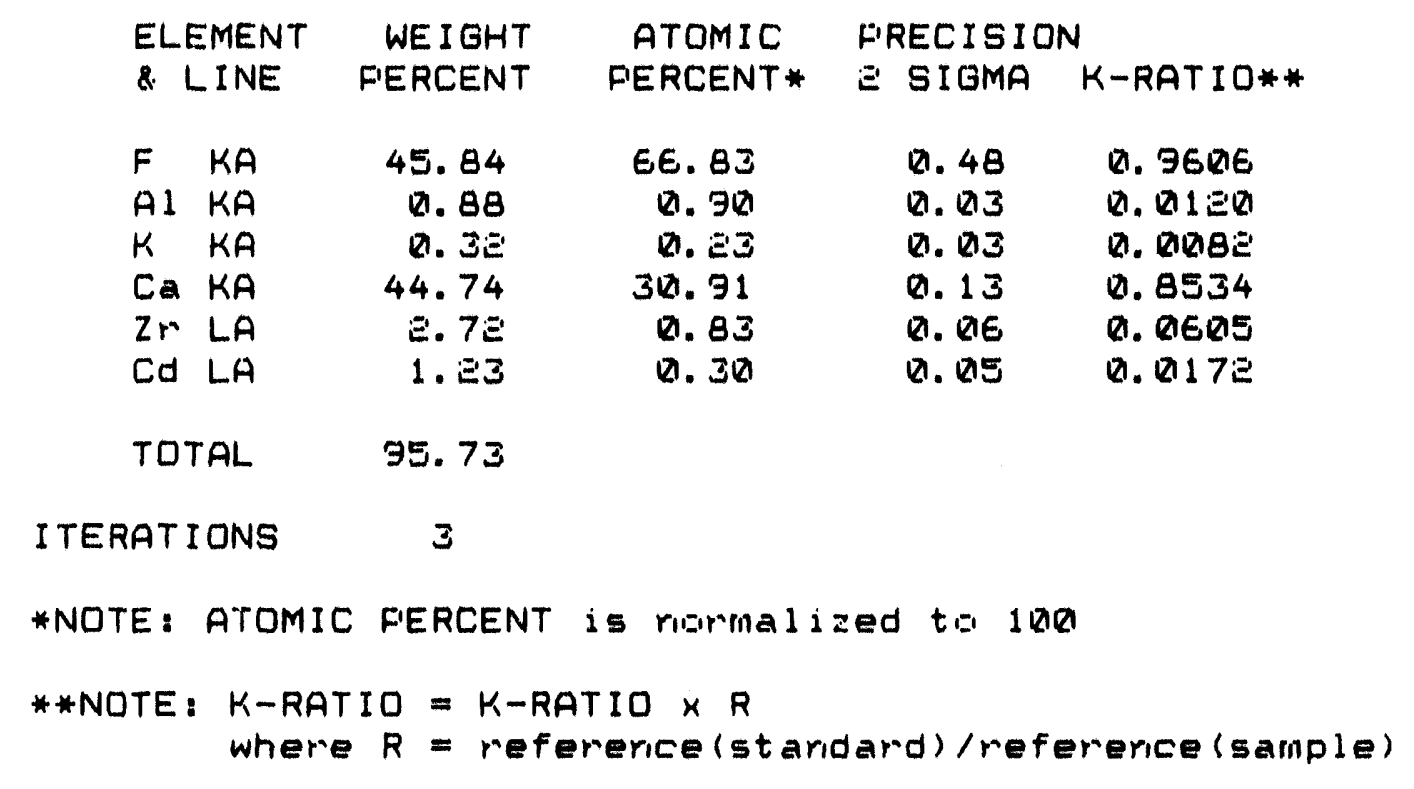




$$
\begin{aligned}
& \text { Acceleratirig voltage EQ⿱ } \mathrm{KeV} \\
& \text { Eeam - sample iriciderice arigle } 90.0 \text { deqrees } \\
& \text { Xray emergerice arigle } 35.0 \text { degrees } \\
& \text { Xray - wiridaw iriciderice arigle }
\end{aligned}
$$

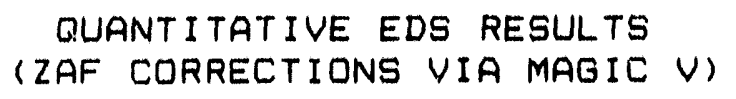

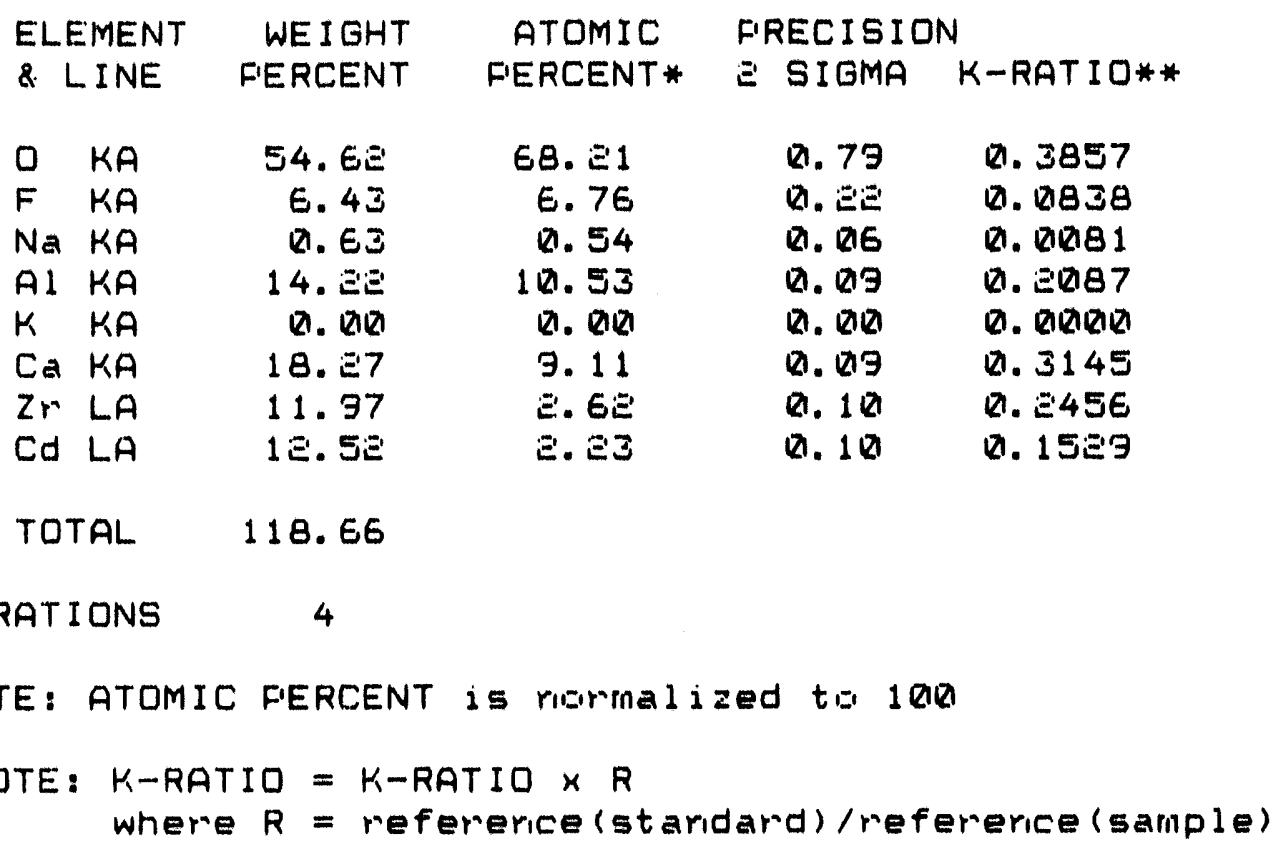




$$
38-N a v-139 \Xi 13: 54: 4 \Xi
$$

Acceleratirig voltage

Eeall - sample iriciderice arigle

xray emergerice arigle

Xray - wiridow iriciderice arigle
R17FLNA-E-4

E(R. Q R KeV

90. (1) degrees

35. Q degrees

Q. (1) degrees

\section{QUANTITATIVE EDS RESULTS \\ (ZAF CORRECTIONS VIA MAGIC V)}

\begin{tabular}{|c|c|c|c|c|c|}
\hline \multicolumn{2}{|c|}{ ELEMENT } & \multirow{2}{*}{$\begin{array}{l}\text { WE I GHT } \\
\text { FERCENT }\end{array}$} & \multirow{2}{*}{$\begin{array}{l}\text { ATOMIC } \\
\text { FEERENT * }\end{array}$} & \multicolumn{2}{|c|}{ F'RECISION } \\
\hline$\&$ & LINE & & & $\Xi$ SIGMA & $K-R A T I O *$ \\
\hline 0 & $K A$ & 19.55 & $=5.8 \square$ & Q. 54 & ㅁ. 1174 \\
\hline$F$ & $K A$ & 43.74 & 48.E1 & D. 48 & Q. 8049 \\
\hline Al & $K A$ & 4. 4E & 3.46 & $D . \Delta G$ & Q. 12613 \\
\hline$k$ & $K A$ & 0.00 & $\nabla .00$ & $\Delta . \Delta \theta$ & Q. बारापित \\
\hline Ca & $K A$ & 38.84 & $E R .4 E$ & D. $1 \Xi$ & ฉ. $7=38$ \\
\hline $2 r$ & LA & $4.6 Q$ & $1 . \Delta E$ & 0.07 & Q. 19938 \\
\hline $\mathrm{Cd}$ & LA & 3.18 & 0.60 & 0.05 & $0.018=7$ \\
\hline
\end{tabular}

TOTAL 114.33

I TERATIONS 5

*NOTE: ATOMIC FERCENT is rigrmalized ta 1 Q18

* NOTE: K-RATIO = K-RATIO $\times R$

where $R=$ refererice (st aridard)/refererice (sample) 


\section{Appondix $\mathrm{C}$}

Point by Point SEM Data For Particle 3

C-1 


$$
30-N a v-199 E 14: 03: 35
$$

Accelerat irig vol tage

Eeari - sample iriciderice arigle

Xray emergerice arigle

xray - wiridaw i riciderice arigle
R1 7FLNA-3-1

E(1). (2) KeV

90. de degrees

35. degrees

Q. Q deqrees

QUANTITATIVE EDS RESULTS
(ZAF CORRECTIONS VIA MAGIC V)

\begin{tabular}{|c|c|c|c|c|c|}
\hline \multicolumn{2}{|c|}{ ELEMENT } & WE IGHT & ATOMIC & \multicolumn{2}{|c|}{ F'RECISIDN } \\
\hline$\&$ & -INE & FERCENT & F'ERCENT* & $\Xi 5 I \mathrm{GMA}$ & K-RATID \\
\hline D & $K A$ & 7.91 & 13.55 & 0.78 & 0.0374 \\
\hline$F$ & $K A$ & 37. $\Xi E$ & 53.68 & Q1. 47 & 21. 6705 \\
\hline A & $K A$ & 0.94 & Q..$\epsilon$ & Q1. 123 & 0.0130 \\
\hline K & $K A$ & 0.35 & จ. $\Xi 4$ & 0.03 & Q. 012185 \\
\hline $\mathrm{C}$ & $K A$ & 43. (12) & $=9.4 \pi$ & Q1. 13 & Q. $B \Omega \in Q$ \\
\hline$N$ & $K A$ & Q. $\Xi E$ & Q1. 1E & (1). 123 & Q. $210=3$ \\
\hline $2 r$ & LA & 5. 31 & $1.6 \Omega$ & Q. 87 & Q7. 1186 \\
\hline $\mathrm{Cc}$ & LA & 1.87 & 0.46 & $\nabla . \nabla \in$ & Q. QUES \\
\hline
\end{tabular}

TOTAL $\quad 96.86$

ITERATIONS 4

*NOTE: ATOMIC FERCENT is rigmalized ta 1 QR

* NOTE: K-RATIO $=K-$ RATIO $\times$ R

where $R=$ refererice (staridard)/refererice (sample) 


$$
3(4-N \boxminus v-199 \Xi \quad 14: 08: \Xi 4
$$

Acceleratirg voltage

Beall - sample iriciderice arigle

xray emergerice arigle

Xray - wiridow inciderice ariale
R17FLNA-3-3

ZU. $\downarrow$ KeV

90.0 degrees

35. Q deqrees

Q. 1 degrees

QUANTITATIVE EDS RESULTS

( $Z A F$ CORRECTIONS VIA MAGIC $V$ )

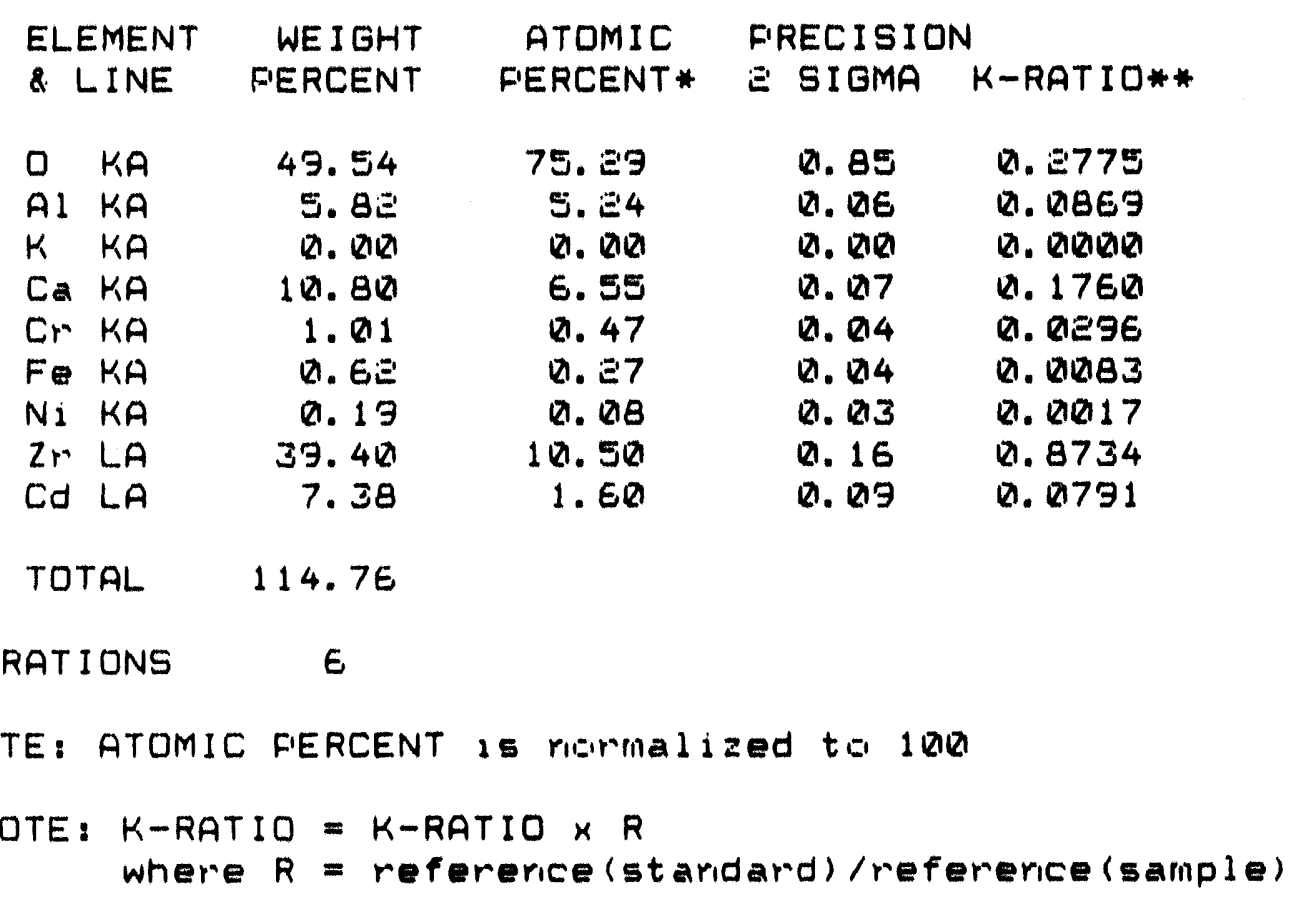




$$
30-N \boxminus v-199 \Xi 14: 13: 13
$$

Acceleratirg voltage

Eeam - sample iriciderice arigle

Xray emergerice arigle

Xray - wiridaw iriciderice arigle
R1 7FLNA-3-3

EQ⿱艹. $Q \mathrm{~K} \in \mathrm{V}$

F⿻. (1) degrees

35.0 degrees

จ. จ degrems

QUANTITATIVE EDS RESULTS

(ZAF CORRECTIONS VIA MAGIC V)

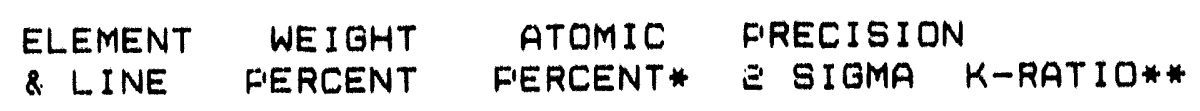

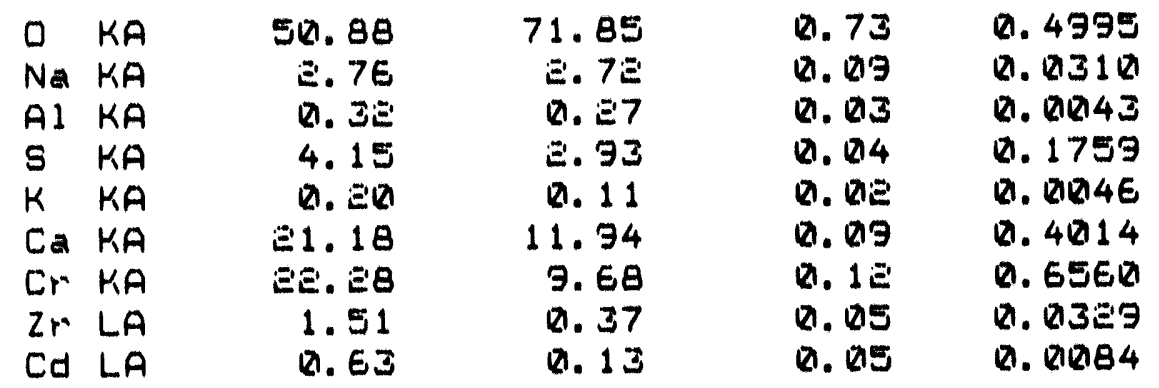

TOTAL 143.91

ITERATIONS 5

*NOTE: ATOMIC FERCENT is riarmalized to 1 QR日a

* NOTE: K-RATIO = K-RATIO $\times R$

where $R=$ mefererice (staridard)/refererice (sample) 


\section{Append1x D}

General Composition SEM Data For small Particles

D-1 


$$
3(1)-N G r-199=11: 36: 41
$$

Acceleratirig viltane

Henali - salloble lriclderice ariqle

Xrav emerqurice arigle

xray - wiridiw iriciderice ariqle
RI TFLNA $-3-13$

Ev. $\mathrm{KeV}$

30.0 deareas

35. deques

ט. d) deques

OUANTITATIVE EDS RESULTS

(ZAF CORRECTIONS VIA MAGIC $V$ )

$\begin{array}{lll}\text { ELEMENT WEIGHT } & \text { ATOMIC FRECISION } \\ \text { \& LINE } & \text { FERCENT FERCENT* I SIOMA K-RATIO** }\end{array}$

D $K A$

F $K A$

Na KA

AI $K A$

S $K A$

K. $K A$

Ca $K A$

Cr. $K A$

Zr LA

Cd LA

31.64

¿5.

1.59

5.14

1. 34

(1) 20

E.ت.

1. 28

13. $5 E$

5. Q14

TOTAL IDE. BR

ITËRATIONS

5

*NOTE: ATOMIC FERCENT is rümallzed to 100

* NOTE: K-RATIO = K-RATIO * $R$

where $R$ = refererice (staridard)/refererice (sample) 


$$
34-N a v-199 a+12113 \text { เ }
$$

Acceleratirg viltane

Heari - vample iriciderice ariqle

xray emeracrice ariqle

xmay - wiridaw iriciderice ariqle
RI TFLNA $-\theta-G$

en. u r.ev

3ท. d) denrees

35. deares

ט. (1) deqrees

OUANTITATIVE EDS RESULTS

(ZAF CORAECTIONS VIA MAGIL $V$ )

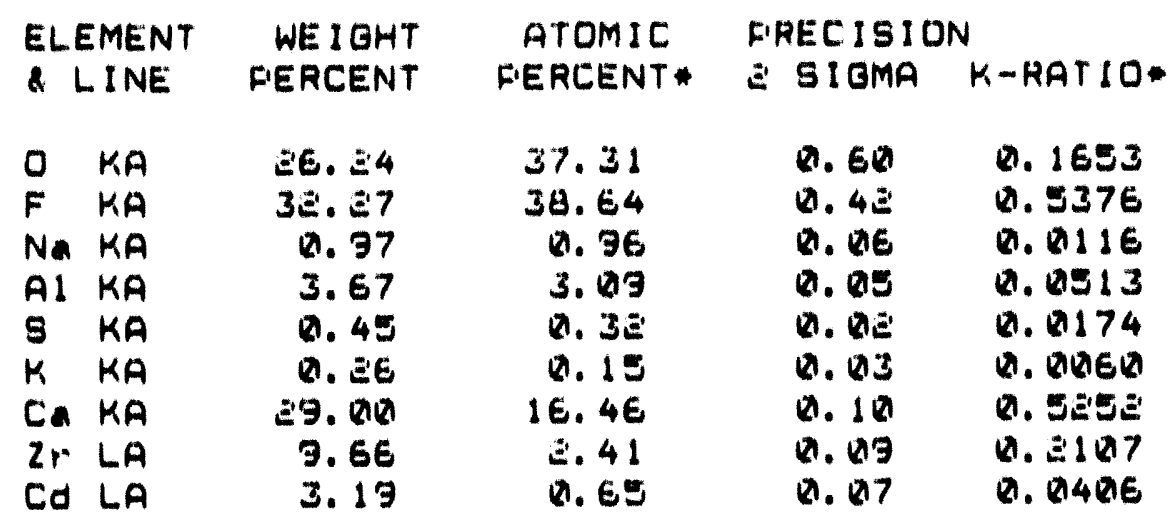

TOTAL 105.71

ITERATIONS $\quad$ E

*NOTE, ATOMIC FERCENT is rigmallaed to 100

* \#NOTEI K-RATIO = K-RATIO * R

whare $R$ - refererice (staridard) refererice (sample) 
Acceleratirig voltage

Enali - sample iriciderice aríale

Xrav emerperice ariale

xray - wiridiew Iriciderice arigle
EQ⿱

90.0 veqrees

35. (1) deqrees

ด. (1) deqrees

\footnotetext{
QUANTITATIVE EDS RESUL.TS

(ZAF CORRECTIONS VIA MAQIC V)
}

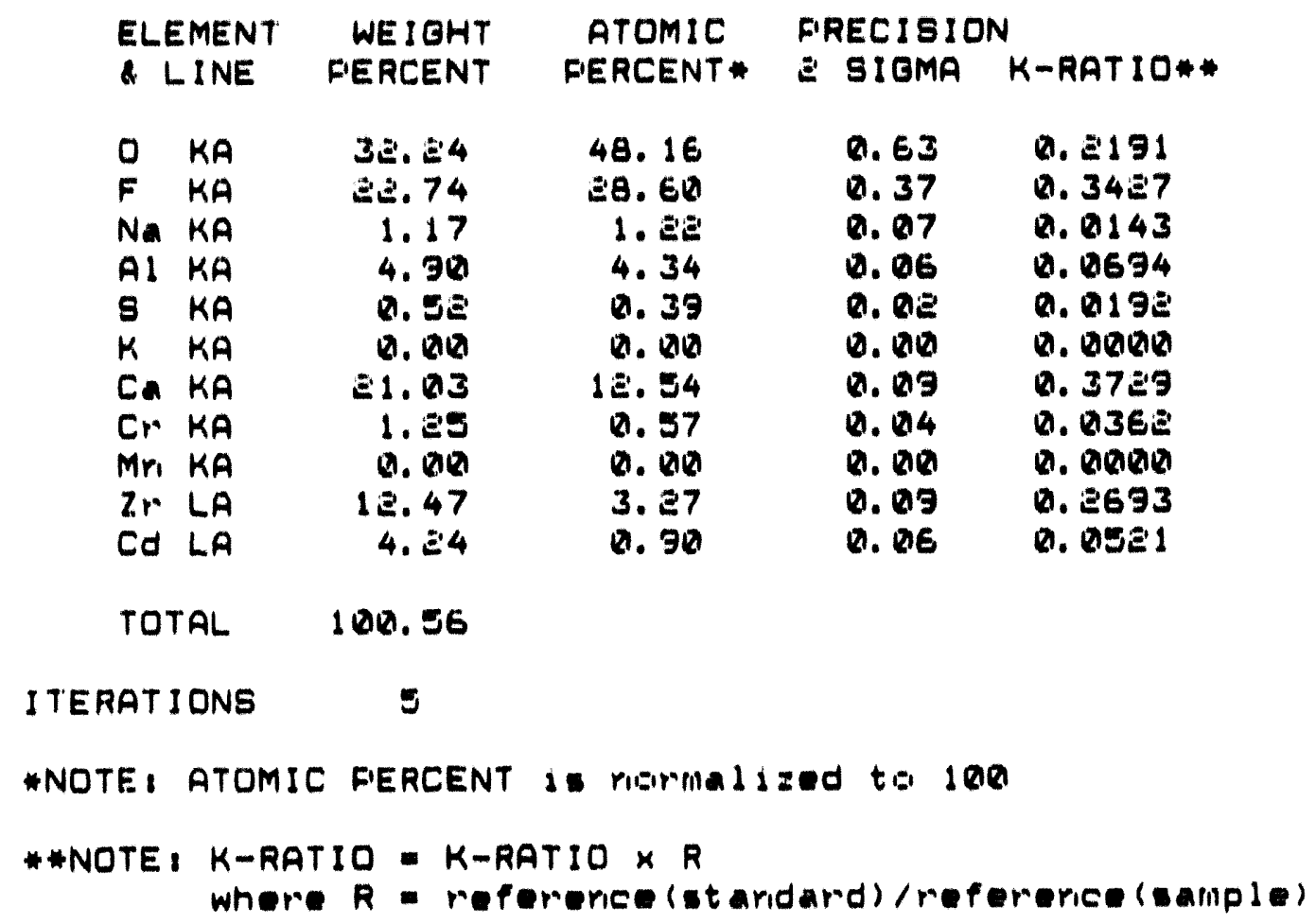




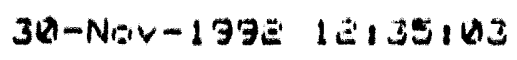

Acceleratirig vilitage

Heam - sample lriclderice ariqle

Xinar emergerice arigle

xpay - wiridaw Iriclderice ariqle
R17FLNA-11-6

E.

3a. d) deques

35. degrees

Q. de deques

\section{QUANTITATIVE EDS RESULTS \\ (ZAF CORRECTIONS VIA MAGIC V)}

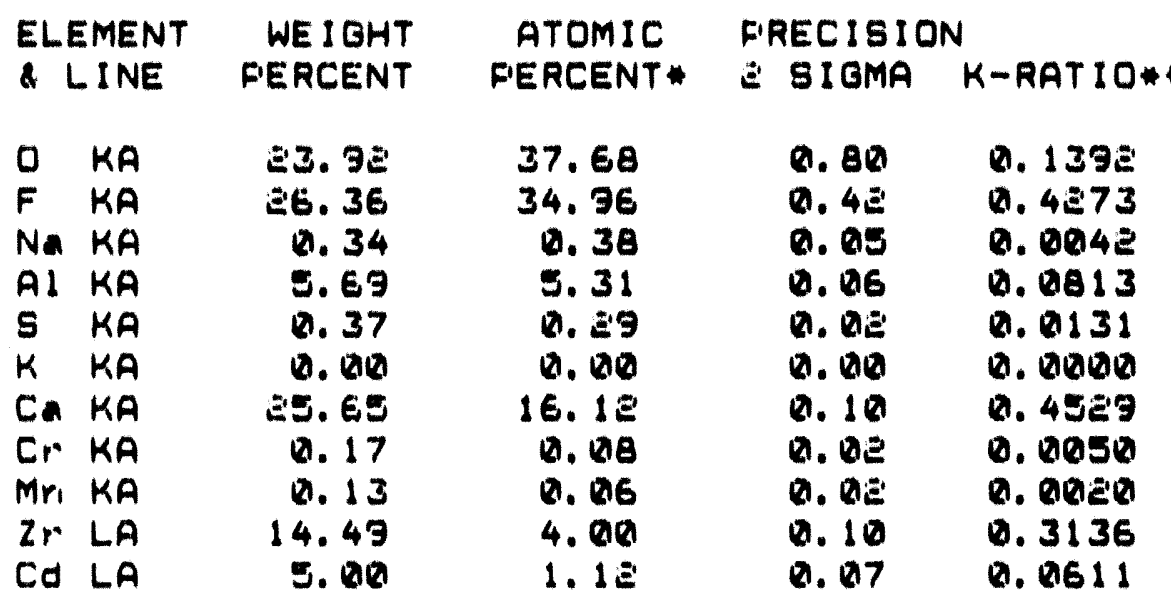

TOTAL IQE. IE

ITERATIONS S

-NOTE, ATOMIC FERCENT is nigrmalized ta 100

* NOTE, K-RATIO = K-RATIO K R

where $R$ = reforerice (staridard)/refererice (sample) 


$$
30-N \operatorname{siv}-199 \pm \quad 1 \pm 139110
$$

Acceleratirig veltage

Eeam - sample iriciderice ariqle

xpay emerperice ariple

xray - windis inciderice ariale
R17FLNA-1Z゙-G

$\Xi \emptyset . \otimes \mathrm{KeV}$

90. deqreas

35. degrees

จ. dequen

\section{QUANTITATIVE EDS RESULTS \\ (ZAF CORRECTIONS VIA MAOIC $V$ )}

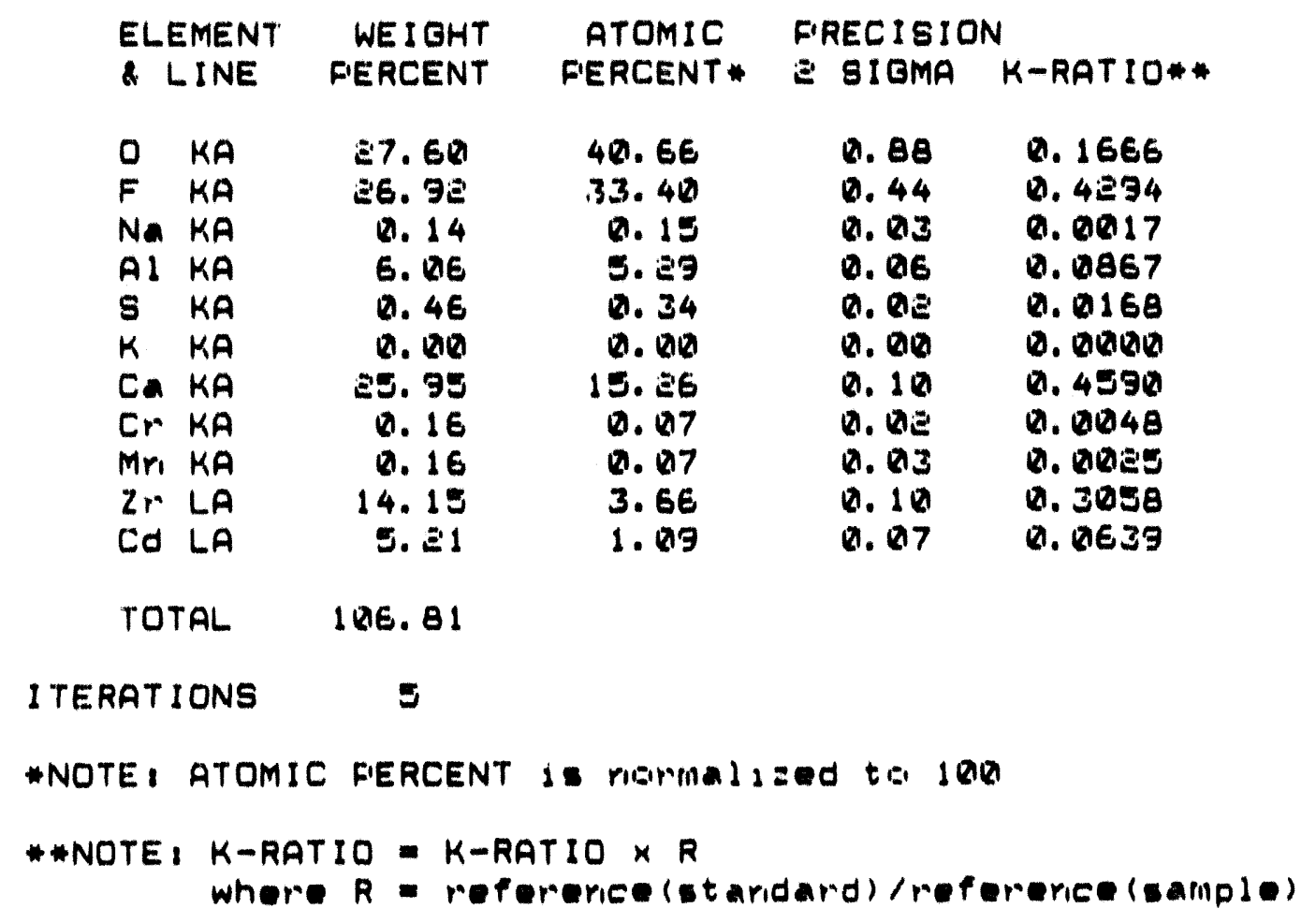




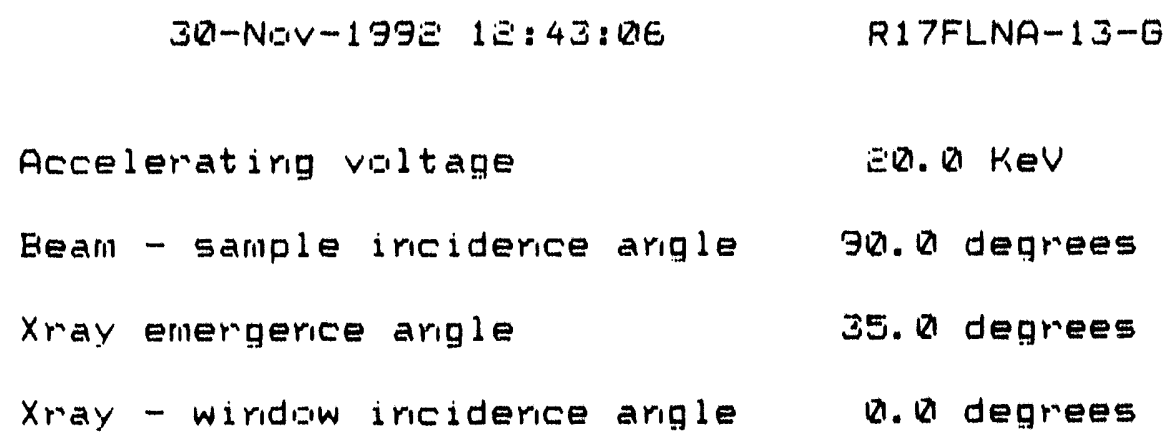

QUANTITATIVE EDS RESULTS

(ZAF CORRECTIONS VIA MAGIC $V$ )

\begin{tabular}{|c|c|c|c|c|c|}
\hline \multicolumn{2}{|c|}{$\begin{array}{l}\text { ELEMENT } \\
\& \text { INE }\end{array}$} & $\begin{array}{l}\text { WE I GHT } \\
\text { FERCENT }\end{array}$ & $\begin{array}{l}\text { ATOMIC } \\
\text { FERCENT* }\end{array}$ & \multicolumn{2}{|c|}{ FRECISION } \\
\hline 0 & $K, A$ & $\Xi ヨ .8 \Xi$ & 43.95 & D. $B E$ & D. $184 \mathrm{E}$ \\
\hline $\mathrm{F}$ & KA & $=4.59$ & 30.52 & 0.43 & Q. 3834 \\
\hline$N=$ & $K A$ & Q. 59 & Q. $E 1$ & QD. $\nabla \mid E$ & 12. 181273 \\
\hline A) & $K A$ & $E . \nabla 9$ & 5.32 & Q. D. & Q. 1872 \\
\hline$s$ & $K A$ & Q. 50 & 0.37 & Q. 03 & Q. 0179 \\
\hline K & $K A$ & Q. Q18 & $\nabla . \nabla \nabla$ & Q. Q10 & Q. बाराष्व \\
\hline $\mathrm{Ce}$ & $K A$ & $=4.011$ & 14.12 & 0.10 & Q. $4 \Xi E 4$ \\
\hline $\mathrm{Cr}_{\mathrm{r}}$ & $K A$ & Q. $\Xi B$ & 0. 13 & Q. 83 & Q. (1)B 1 \\
\hline Mr & $K A$ & 0.10 & Q1. 124 & Q. D. & Q. \\
\hline $2 r$ & LA & 15.10 & 3.90 & 0.10 & ๑. उЕE 1 \\
\hline $\mathrm{Cd}$ & LA & 4.97 & 1. 874 & Q1. 127 & 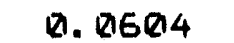 \\
\hline
\end{tabular}

TOTAL 106. 124

ITERATIONS 5

*NOTE: ATOMIC FERCENT is rigmalized ta 100

* NOTE: K-RATIO $=K$-RATIO $K R$

where $R=$ refererice (staridard)/refererice (sample) 


\section{Appondix $\mathbf{E}$}

General Composition SEM Data For Medium Particles

E-1 


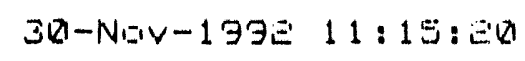

Acceleratirig voltage

Beari - sample lriciderice arigle

Xray emergerice ariale

Xray - wiridiw imciderice arigle
R1 TFLNA-ËーG

EQ⿱艹 $\mathrm{K} \in \mathrm{V}$

Fu. deqrees

35. dequees

Q. Q deqrees

\footnotetext{
QUANTITATIVE EDS RESULTS

( $Z$ AF CORRECTIONS VIA MAGIC $V$ )
}

$\begin{array}{lll}\text { ELEMENT } & \text { WEIGHT } & \text { ATOMIC FIRECISION } \\ \text { \& LINE } & \text { FERCENT FIERCENT* E SIGMA K-RATIO** }\end{array}$

\begin{tabular}{|c|c|c|c|c|c|}
\hline 0 & $K A$ & $32 \pi .51$ & $4 \Xi .47$ & ㄱ. $\epsilon \Xi$ & ㅁ. $19 \in 4$ \\
\hline$F$ & $K A$ & $=7.40$ & $3 \Xi .88$ & $0.4 \pi$ & 1. 4347 \\
\hline $\mathrm{Na}$ & $K A$ & ฉ. 155 & จ. 54 & ฉ. 124 & ฉ. $\nabla \nabla \in E$ \\
\hline Al & $K A$ & 5. 23 & 4. $4 E$ & $\nabla . \Delta \theta \epsilon$ & จ. 12741 \\
\hline 5 & $K A$ & Q1. $5 \nabla$ & (1). 35 & Q. $\theta=$ & D. $\nabla 18 E$ \\
\hline K & $K A$ & ㅁ. $1 \Xi$ & Q1. 127 & 0.03 & ฉ. $\Delta \otimes \equiv 7$ \\
\hline $\mathrm{Ca}$ & $K A$ & $=4.7 \square$ & $14.1 \epsilon$ & Q1. 10 & (1). 44E9 \\
\hline $\mathrm{Cr}$ & $K A$ & $\nabla .1 \epsilon$ & 0.077 & $\Delta . \Delta E$ & (1). 1045 \\
\hline $\mathrm{Zr}$ & LA & 11.79 & $\Xi .95$ & 12. 183 & (12. 2548 \\
\hline $\mathrm{Cd}$ & LA & 5.31 & 1.118 & Q. $\nabla 18$ & $\nabla . \Delta \in \in 1$ \\
\hline
\end{tabular}

TOTAL $\quad$ DUE. 47

ITERATIONS 5

*NOTE: ATOMIC FERCENT is rümalized ta 100

* NOTE: K-RATIO $=K$-RATIO $\times R$

where $R=$ refererice (staridard)/refererice (sample) 


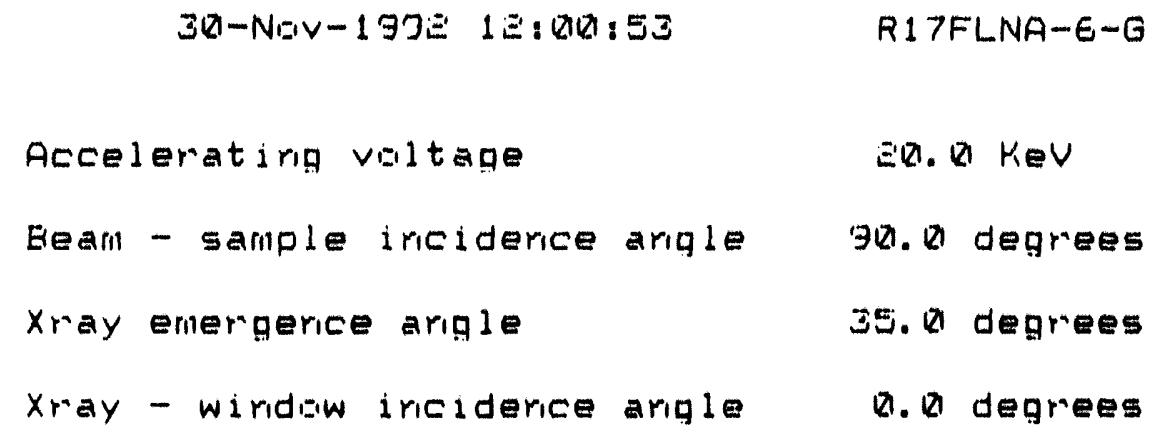

QUANTITATIVE EDS RESULTS

(ZAF CORRECTIONS VIA MAGIC V)

\begin{tabular}{|c|c|c|c|c|c|}
\hline \multicolumn{2}{|c|}{ ELEMENT } & $\begin{array}{l}\text { WE I GHT } \\
\text { F'ERCENT }\end{array}$ & $\begin{array}{l}\text { ATOMIC } \\
\text { FEERCENT * }\end{array}$ & \multicolumn{2}{|c|}{ FRECISION } \\
\hline 0 & $K A$ & 30.38 & 45.37 & R. EE & (1. $\Xi 1749$ \\
\hline$F$ & $K A$ & E5. 11 & 31.58 & Q. 40 & 0.3940 \\
\hline Ne & $K A$ & 1. 05 & 1. 129 & Q. QE & Q. $01=8$ \\
\hline Al & $K A$ & 4.98 & 4.41 & $\Delta . \Delta 6$ & 0.0707 \\
\hline 5 & $K A$ & Q1. $\Xi 6$ & 0.19 & Q. DE & Q. 1094 \\
\hline$C_{1}$ & KA & 0.17 & Q1. 11 & Q. Q DE & Q. $\Delta \Delta \nabla=3$ \\
\hline$K$ & $K A$ & Q. $\nabla 12$ & Q. Q12) & Q1. Q120 & Q. QRाä \\
\hline $\mathrm{Ca}$ & $K A$ & Еコ. ロ & 13.13 & Q. $\Delta 9$ & ด. 39こЗ \\
\hline $\mathrm{Cr}$ & KA & Q. $4 E$ & Q. $=1$ & Q. $\Delta$. & Q. $013 \Xi$ \\
\hline $\mathrm{Mr}$ & $K A$ & Q. $\nabla Q$ & Q. Q10 & Q. D. & 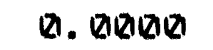 \\
\hline $2 n$ & LA & $1 \Xi .41$ & 3.5 & D. D. DI & Q. 1683 \\
\hline $\mathrm{Cd}$ & LA & 3.13 & Q. 66 & Q1. 06 & 0.0384 \\
\hline
\end{tabular}

TOTAL $\quad$ 99. 38

ITERATIONS 5

*NOTE: ATOMIC FERCENT is rigrmalized ta 1 QR

* NOTE: K-RATIO $=K$-RATIO $\times R$

where $R=$ refererice (staridard)/refererice (sample) 


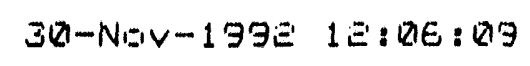

Acceleratirg viltage

Beam - sample iriciderice amale

Xray emergerice arigle

Xray - wiridaw iriciderice arigle
R1 7FLNA-7--G

Eख. Ku KeV

$9(1$.$) degrees$

35. Q degrees

(1) D degrees

QUUANTITATIVE EDS RESULTS

(ZAF CORRECTIONS VIA MAGIC $V$ )

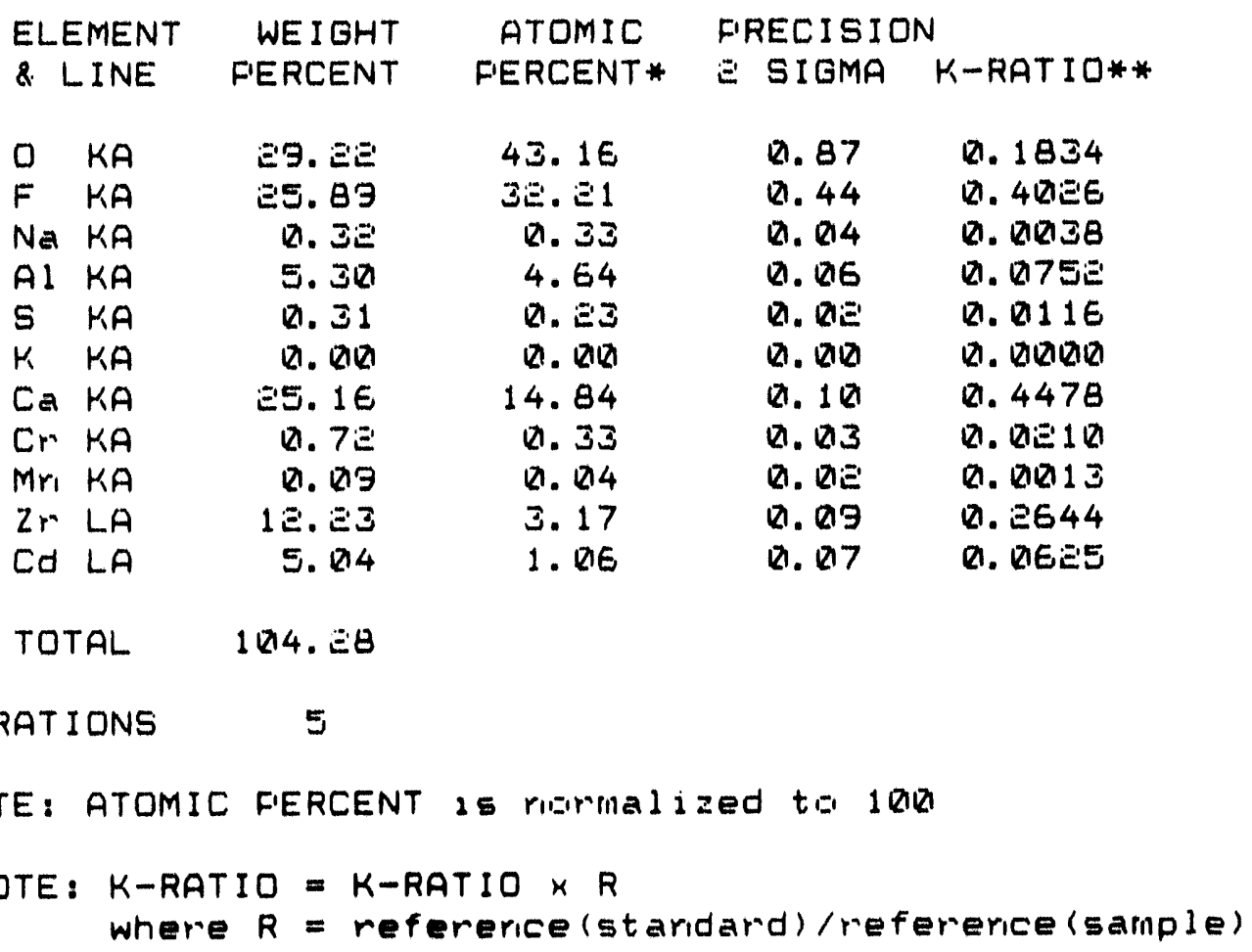


Acceleratirg valtage

Eeari - sample iriciderice argle

xray emergerice arigle

xray - wiridow iriciderice arigle
ER. R KeV

(98. (1) degrees

35. de degrees

Q. D) deqrees

QUANTITATIVE EDS RESULTS

(ZAF CORRECTIONS VIA MAGIC $V$ )

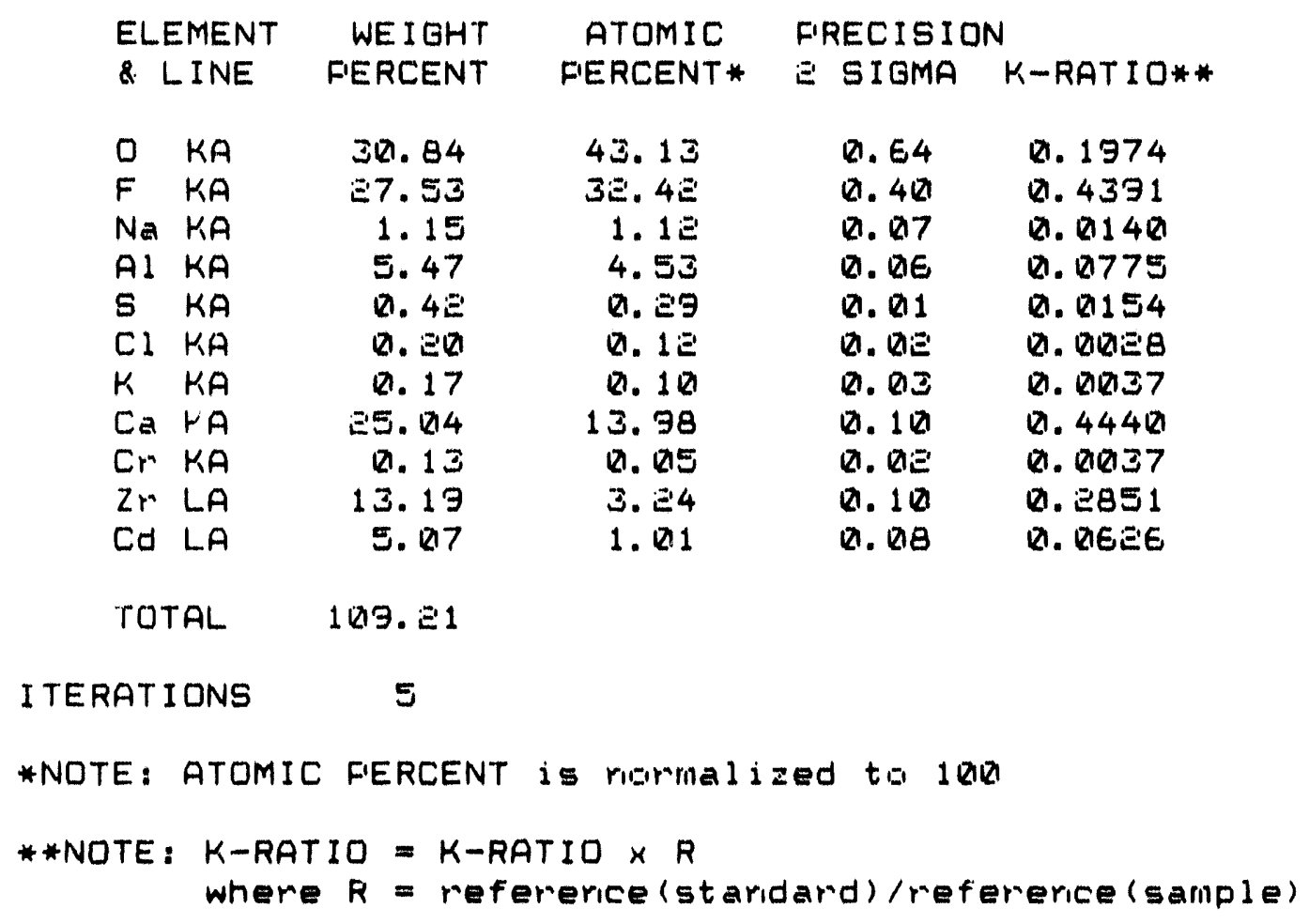




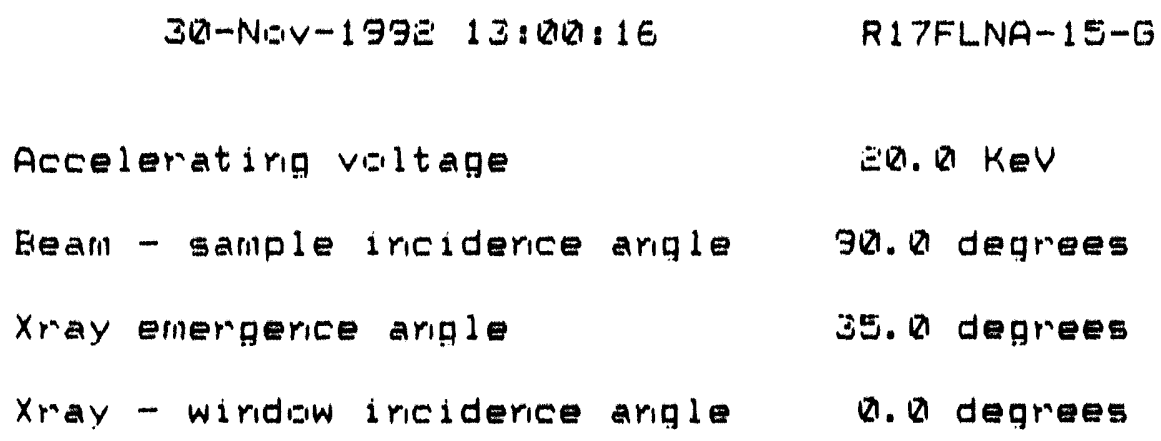

QUANTITATIVE EDS RESULTS

(ZAF CORRECTIONS VIA MAGIC V)

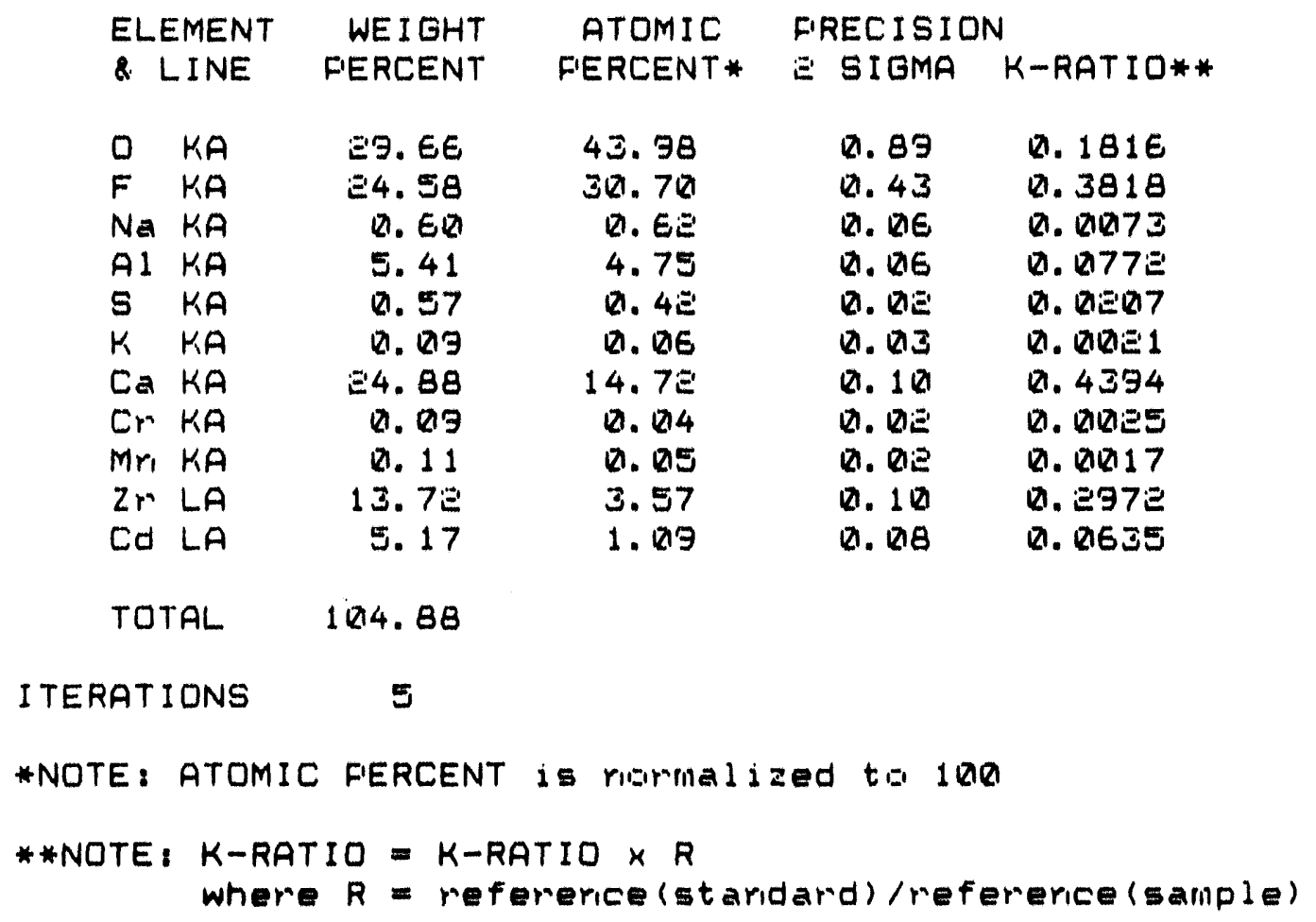


Appondix $\mathbf{I}$

General Composition SEM Data For Large Particles 


$$
3(x-N a v-199 z 10: 56: 50
$$

Acceleratipig viltage

Bearl - sample l riciderice aride

Xray emerperice arigle

Xray - wiridiw iriciderice arigle
RITFLNA-1-G

ED. (1) KeV

9u. deqrees

35.0 degrees

(4.) deqrees

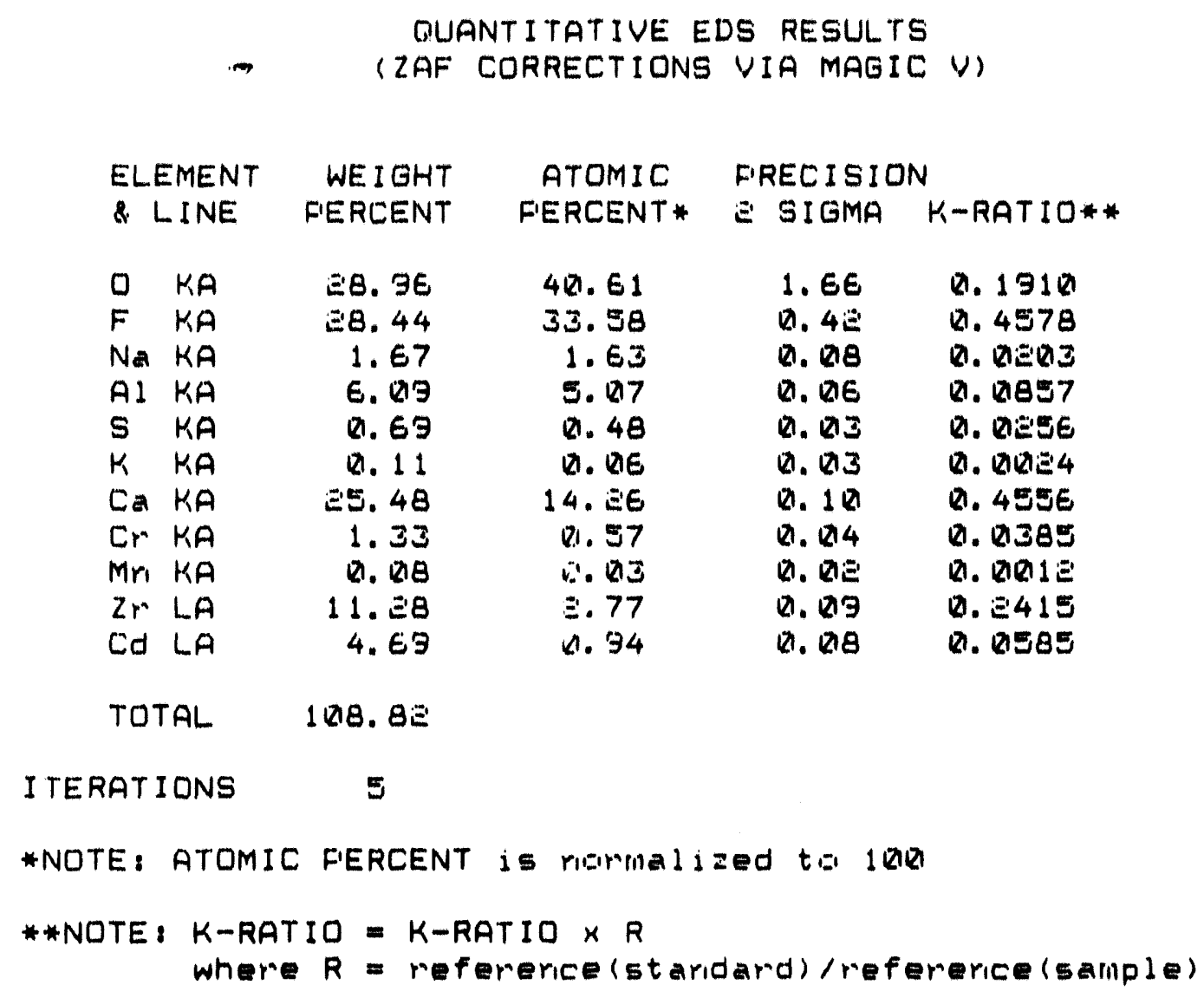




$$
30-N a v-199 a j 11,40,48
$$

Acceleratirig voltage

Heari - Sanple iriclderice ariqle

Xray emerperice ariple

Xray - wiridow iricidence arigle
R1 7FLNA-4-G

EQ. $\mathrm{KeV}$

90. deqrees

35. degrees

Q. (1) degrees

\footnotetext{
QUANTITATIVE EDS RESULTS

(ZAF CQRRECTIONS VIA MAGIC V)
}

\section{ELEMENT WEIGHT ATOMIC FRECISION \\ \& LINE FIERCENT FIERCENT* E SIGMA K-RATIO**}

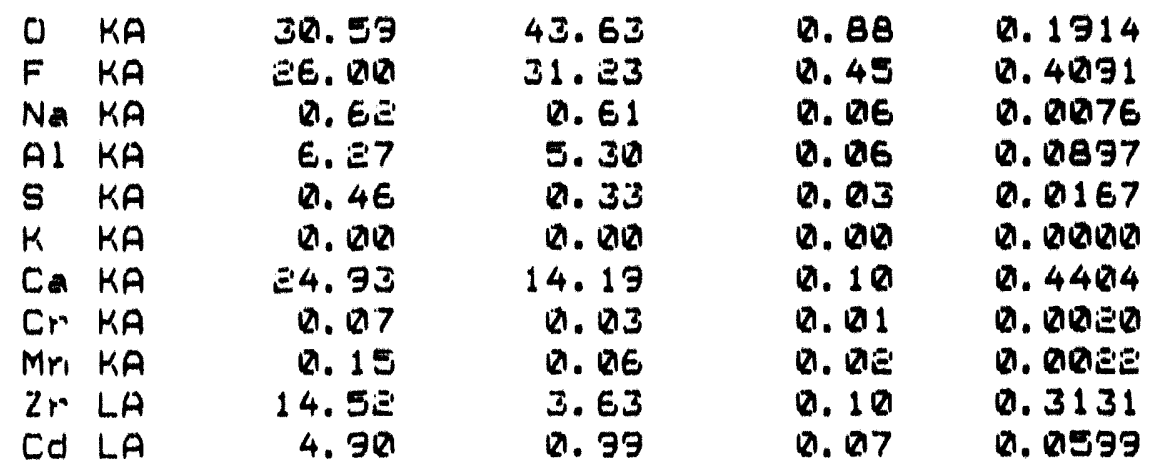

TOTAL 1 INB. 51

ITERATIONS

*NOTE: ATOMIC FERCENT Is rismmalized tei 1 QuQ

* NOTE: K-RATIO = K-RATIO $\times R$

where $R=$ refererice (staridard)/refererice (sample) 


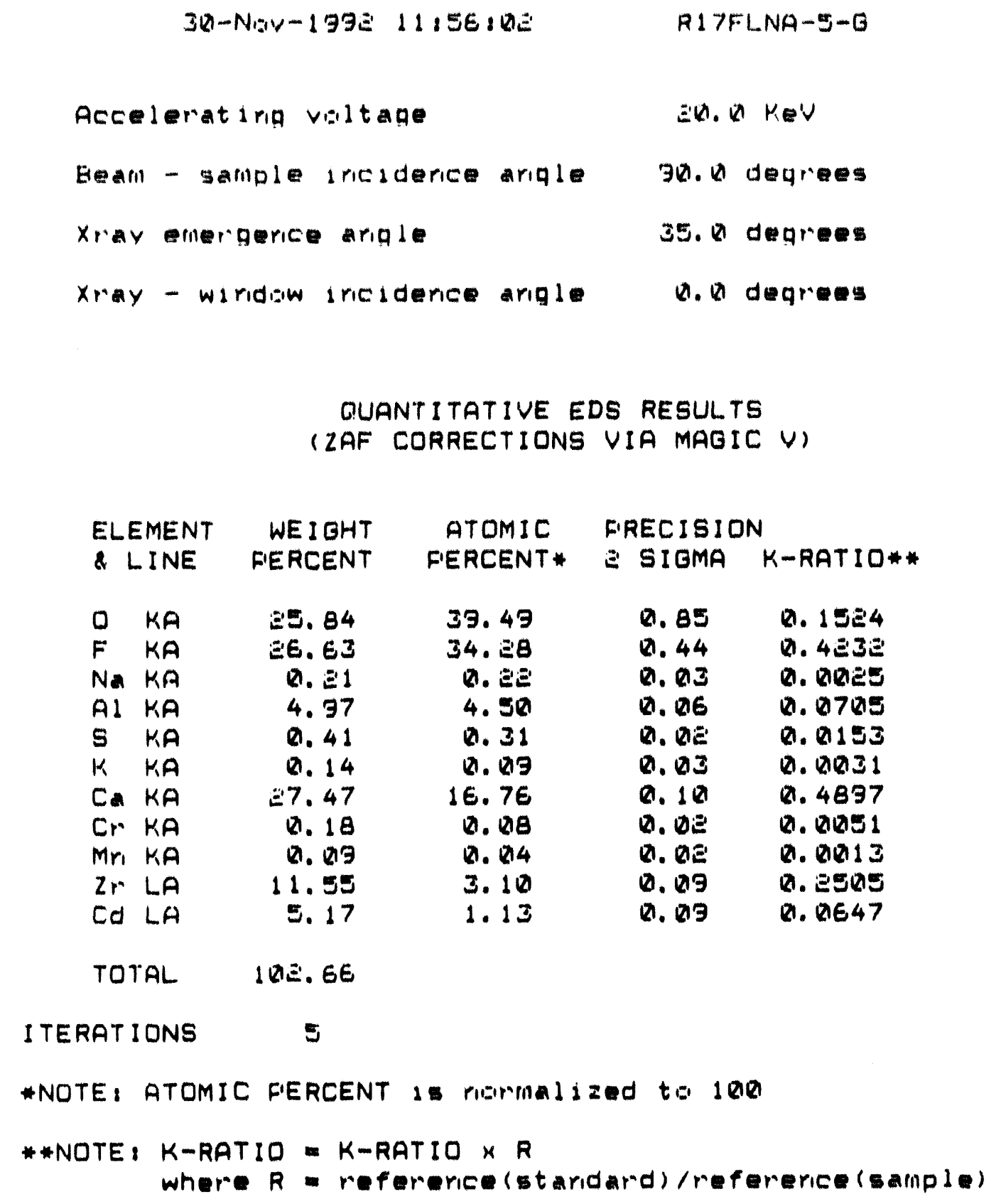




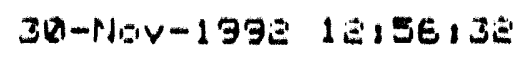

R1 7FLNA $-14-G$

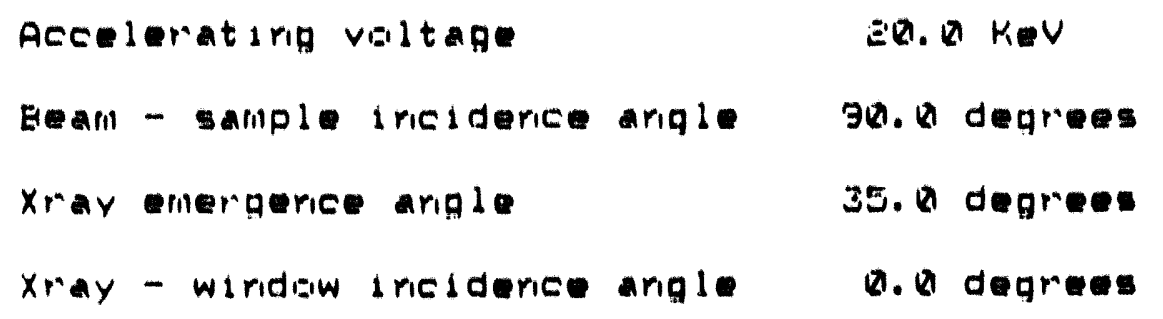

QUANTITATIVE EDS RESULTS

(ZAF CORRECTIONS VIA MAGIC V)

\section{ELEMENT WEIGHT ATOMIC FRECISION \\ \& LINE FERCENT FIERCENT* I SIGMA K-RATIO**}

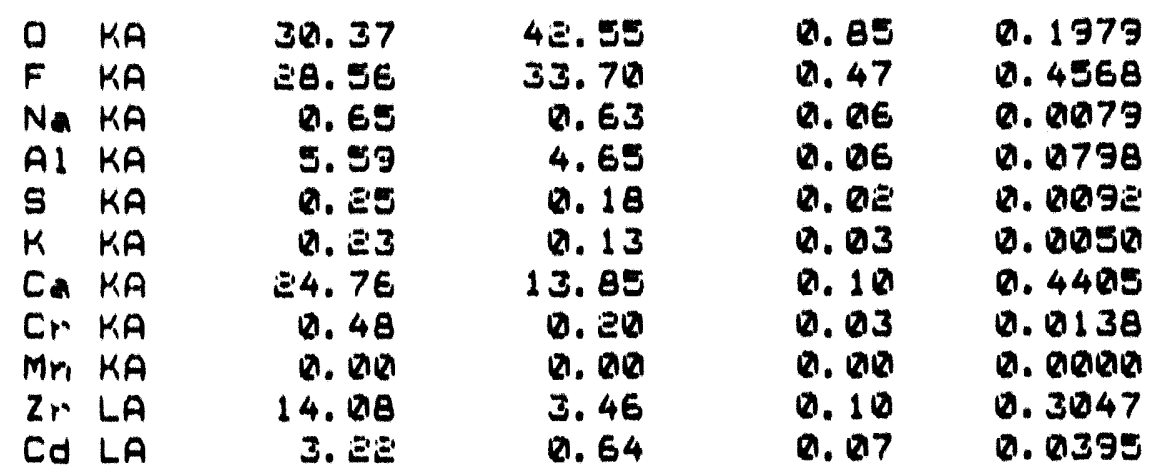

TOTAL 108.19

ITERAT IONS

5

*NOTE, ATOMIC FERCENT is Minmalized to 100

* NOTEI K-RATIO = K-RATIO X R

where $R$ = refererice (staridard)/refererice (sample) 
Append1x 0

XPS Raw Data

G-1 


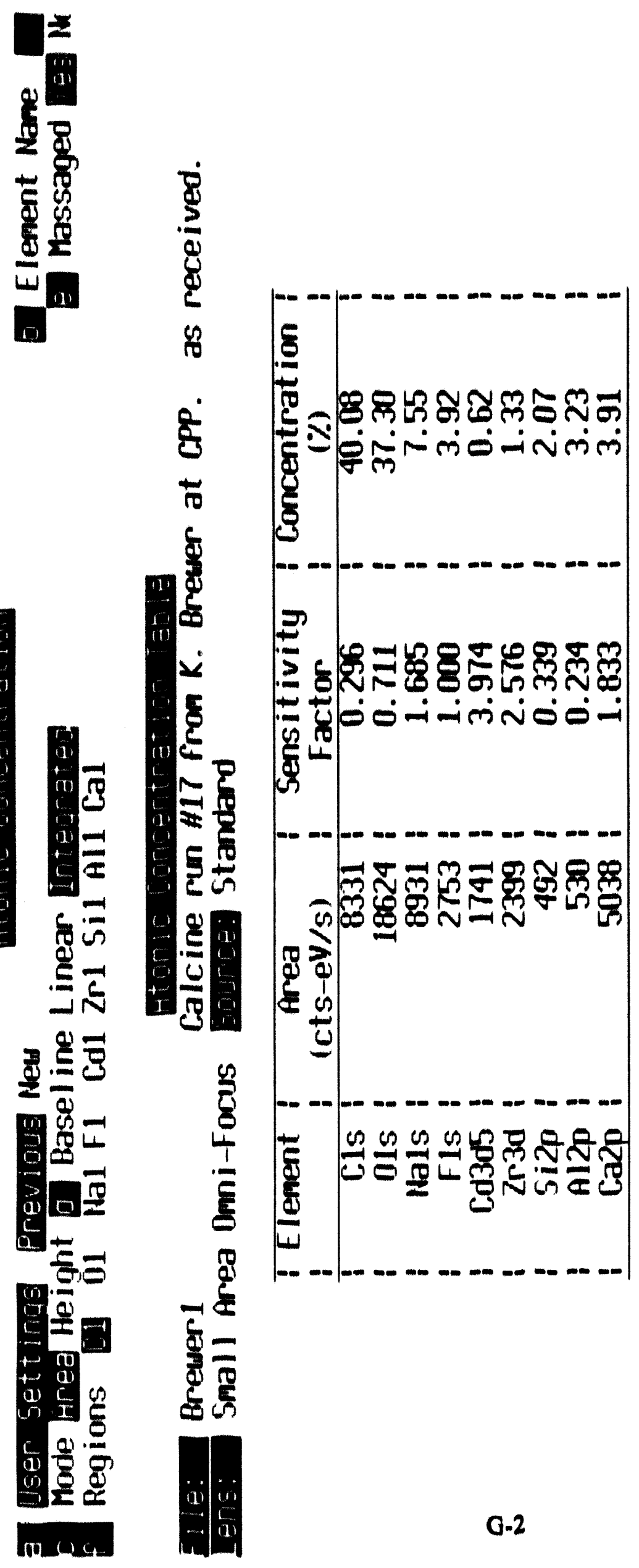




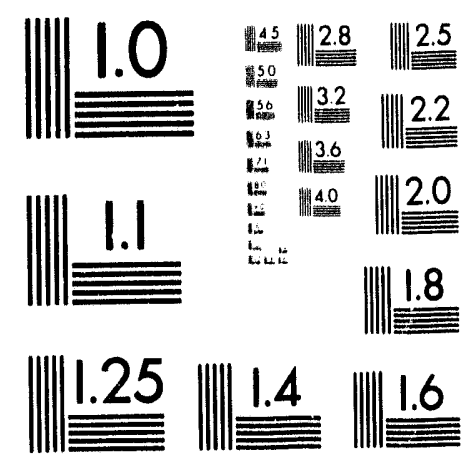



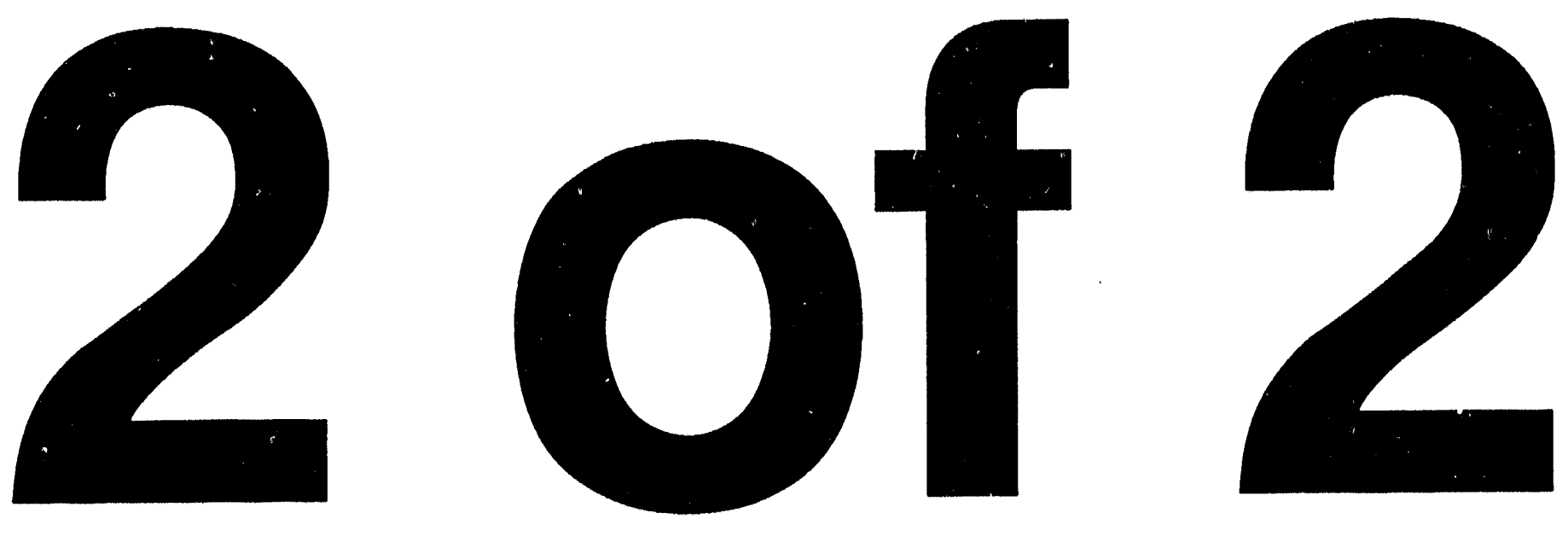


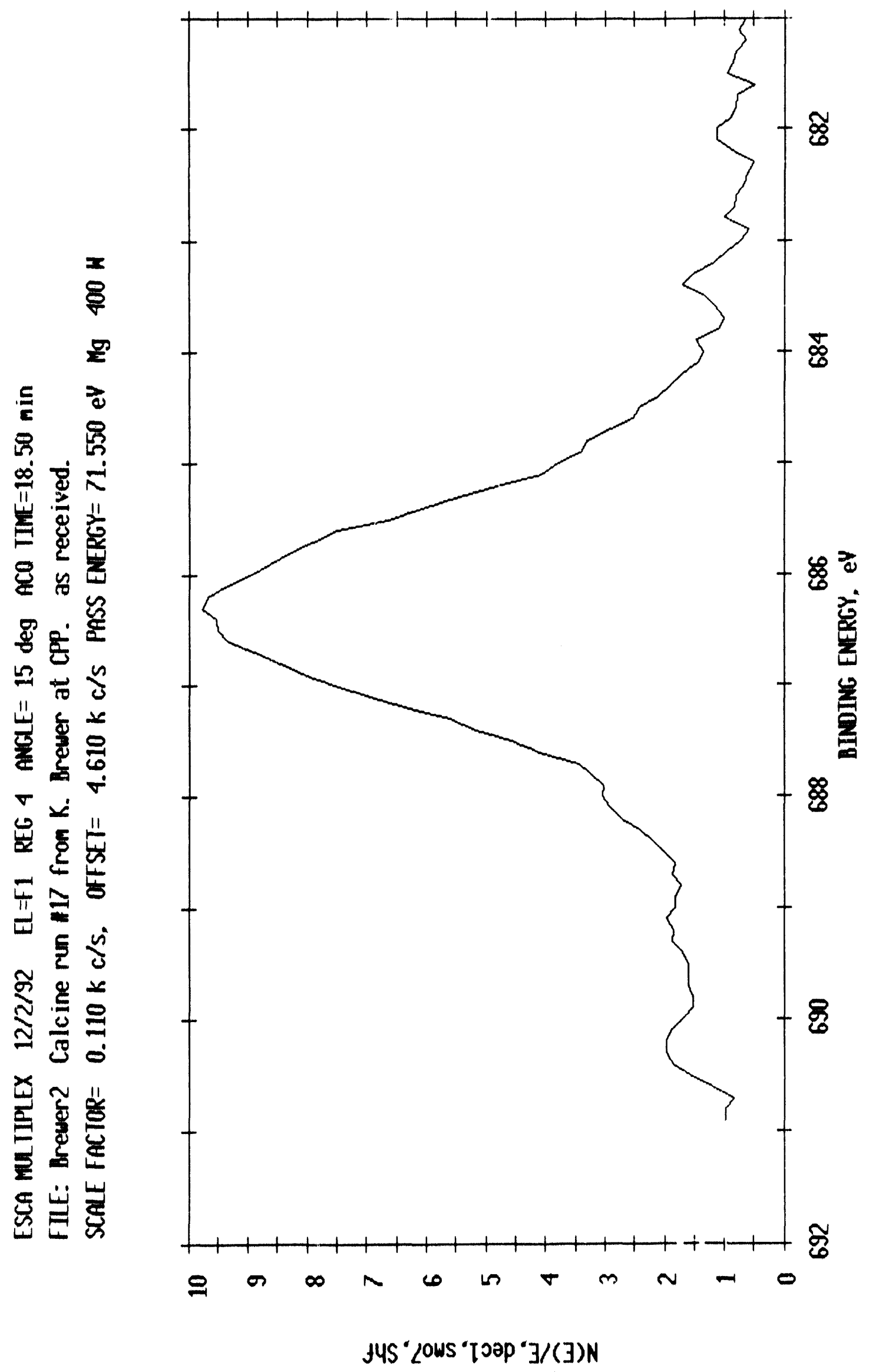




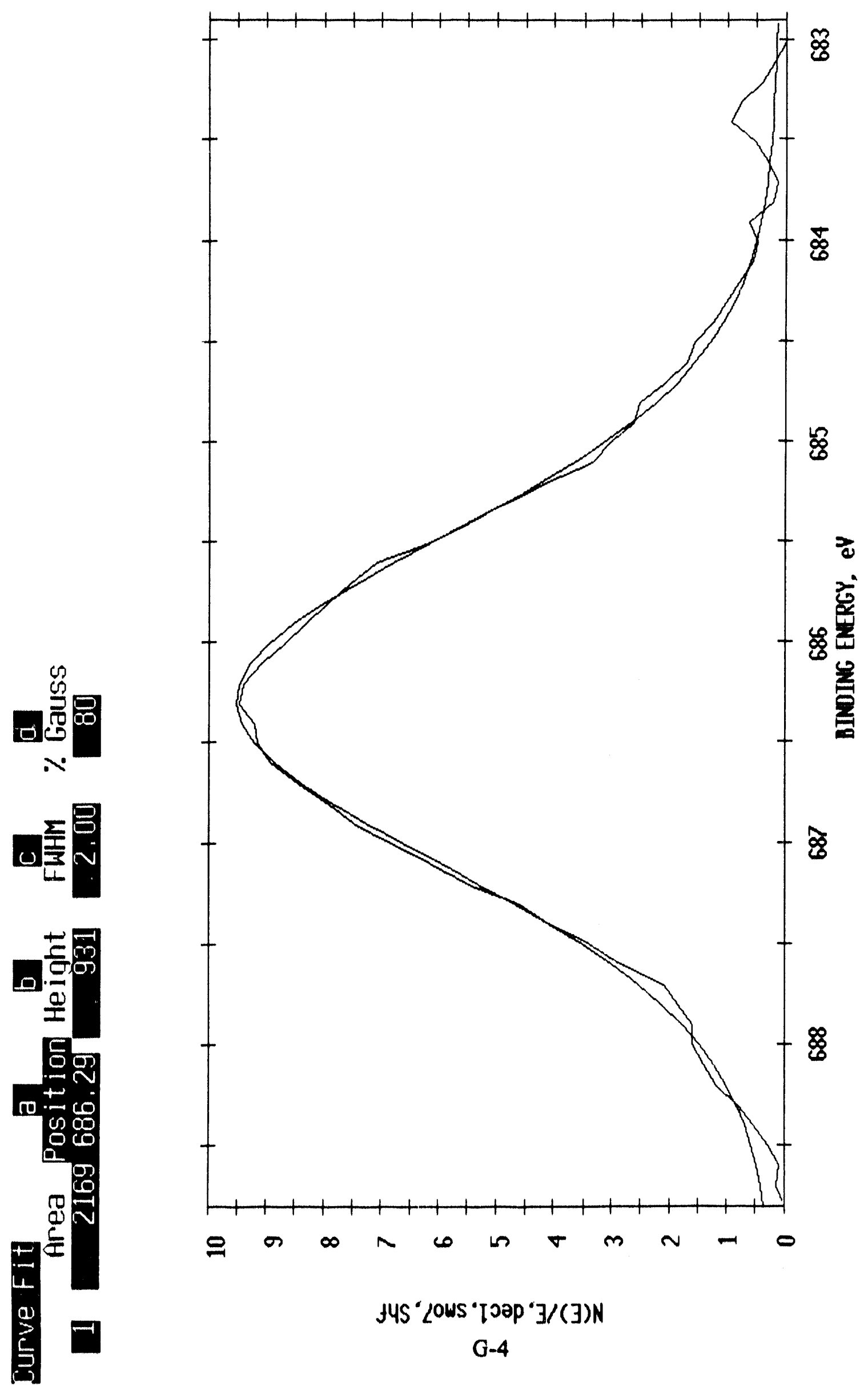




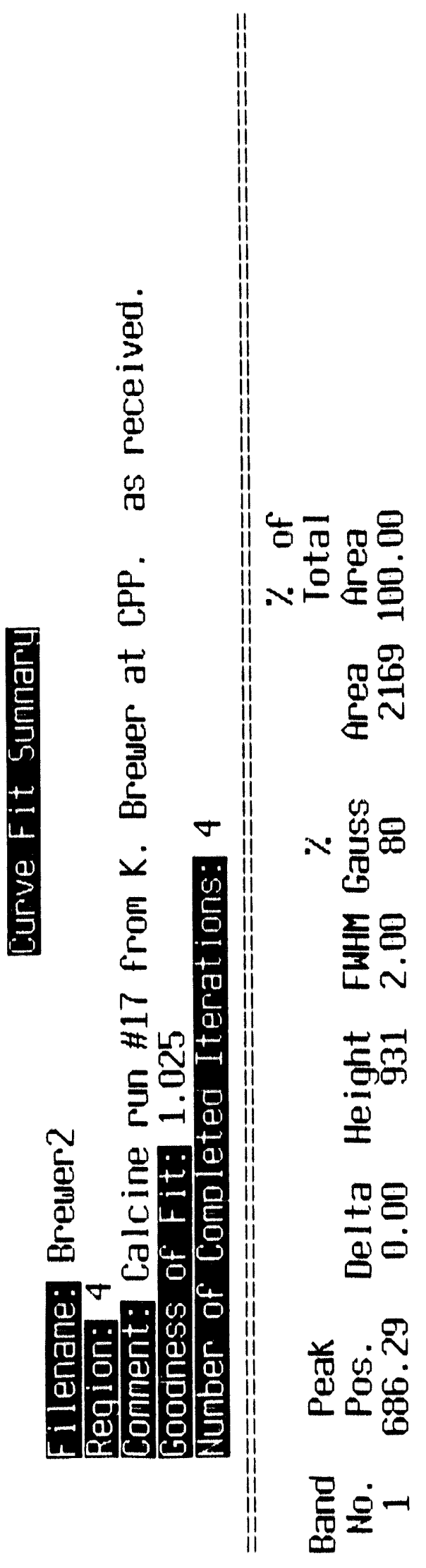




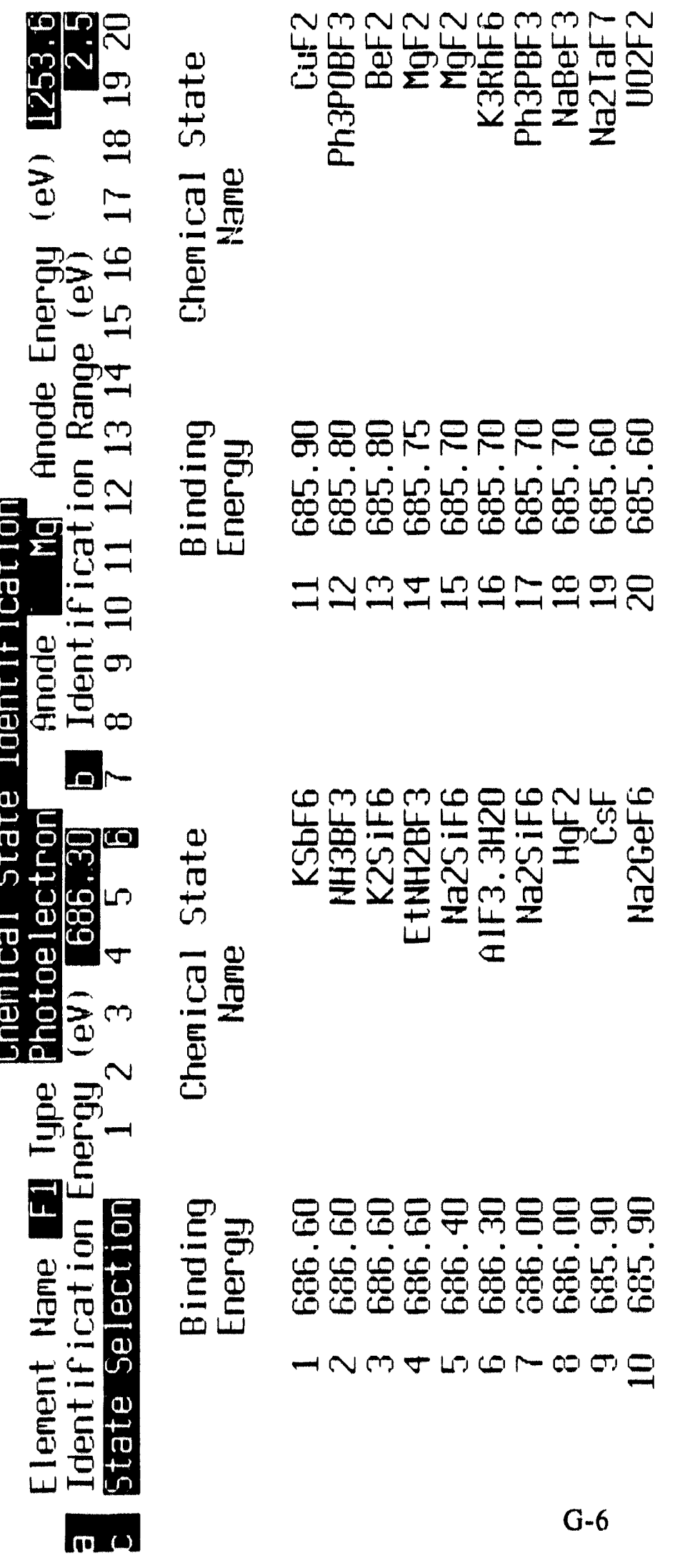




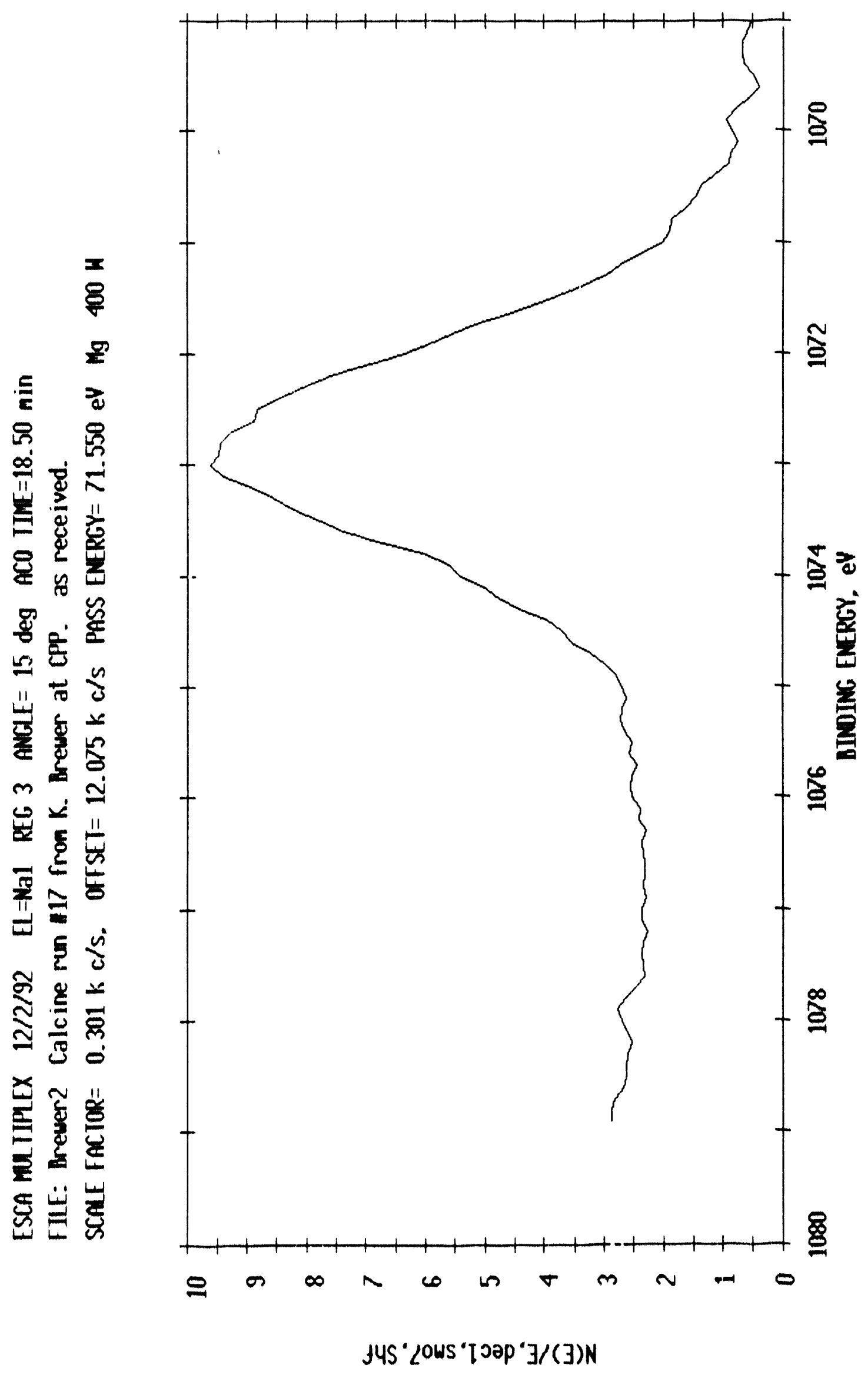

G-7 


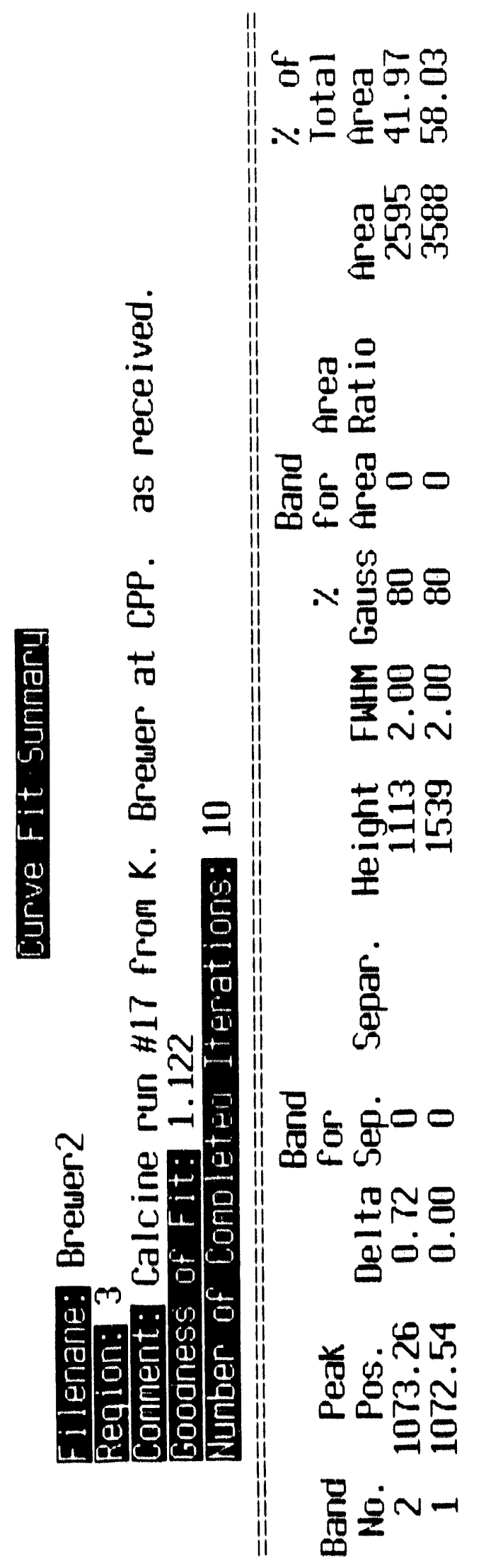

G-8 


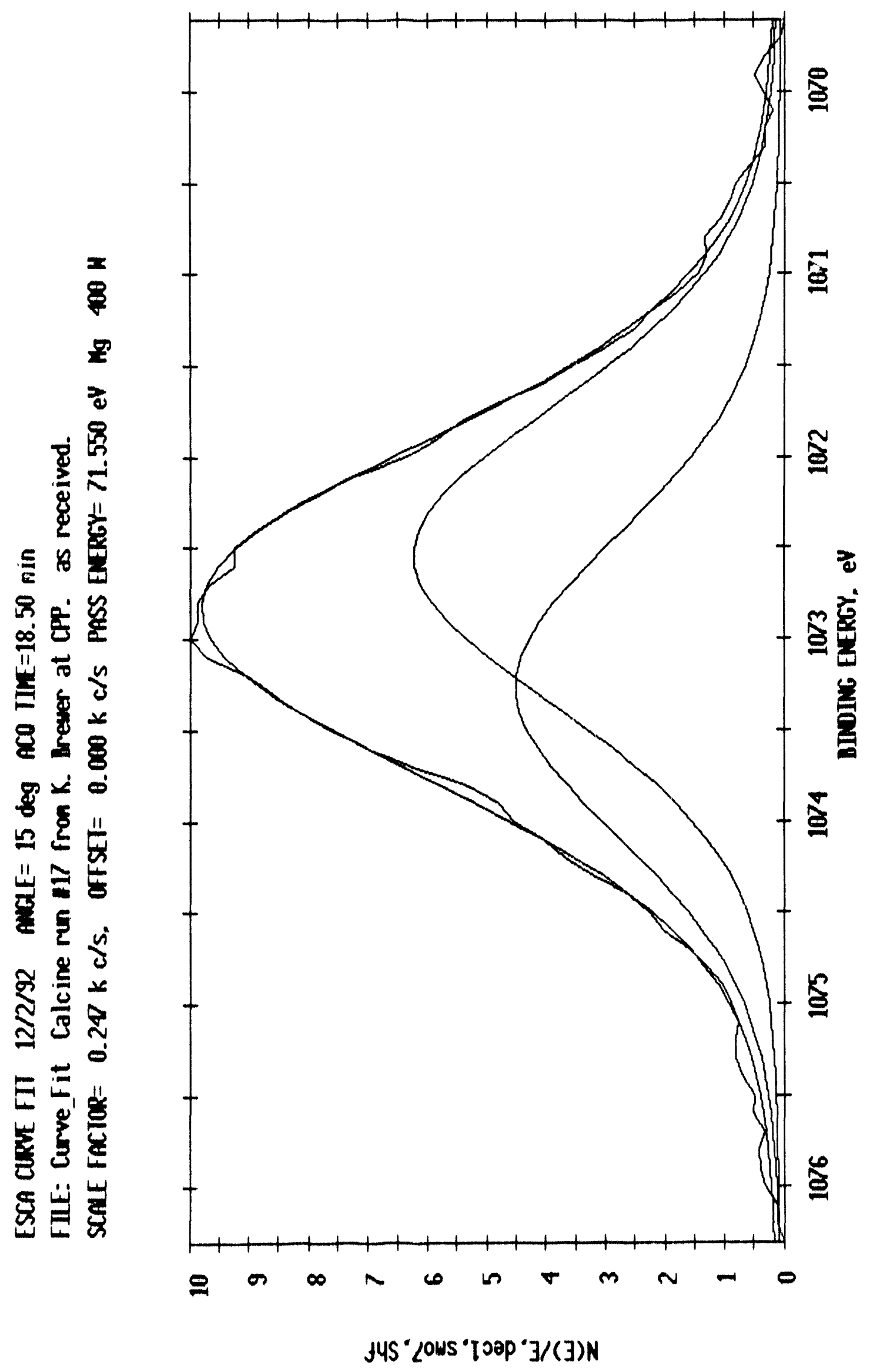

G-9 


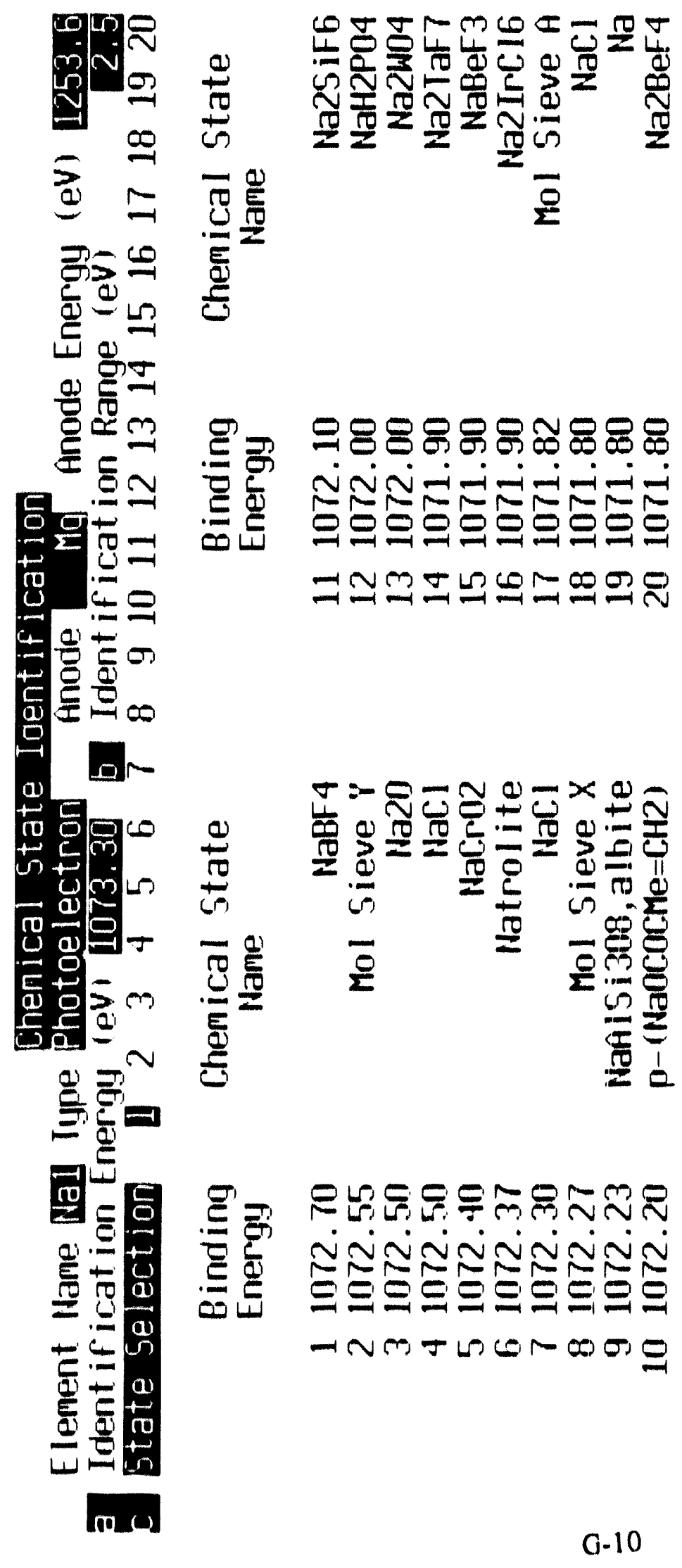




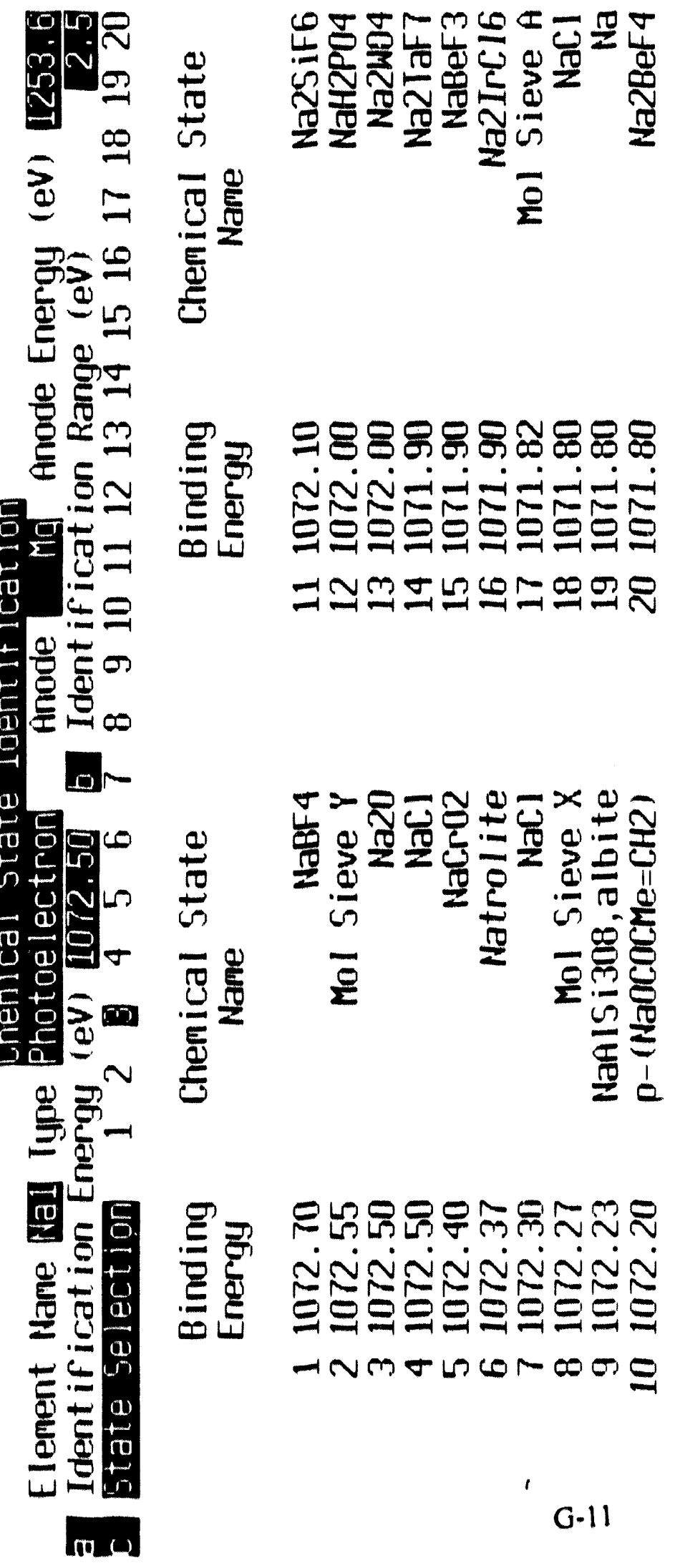




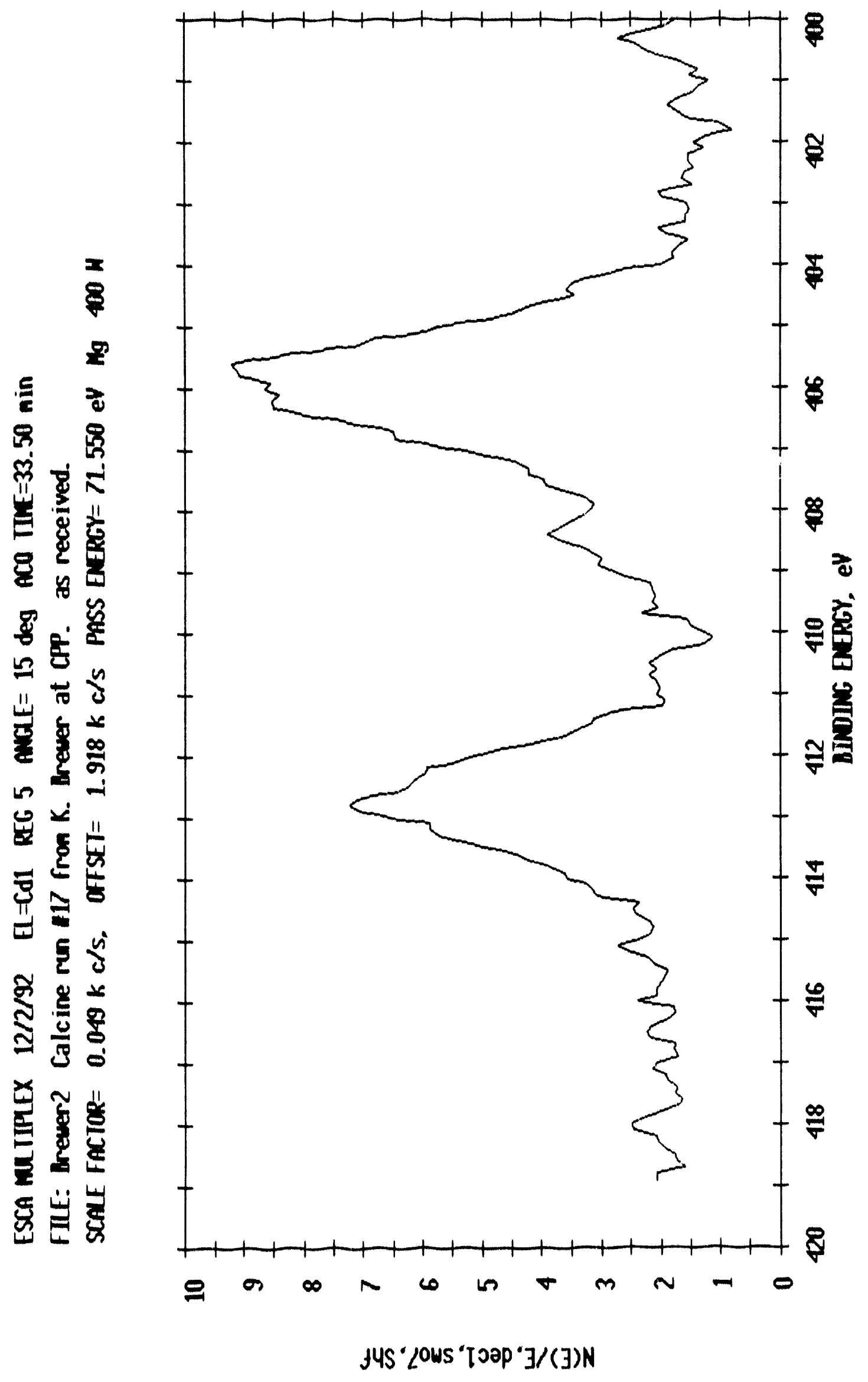

G.12 


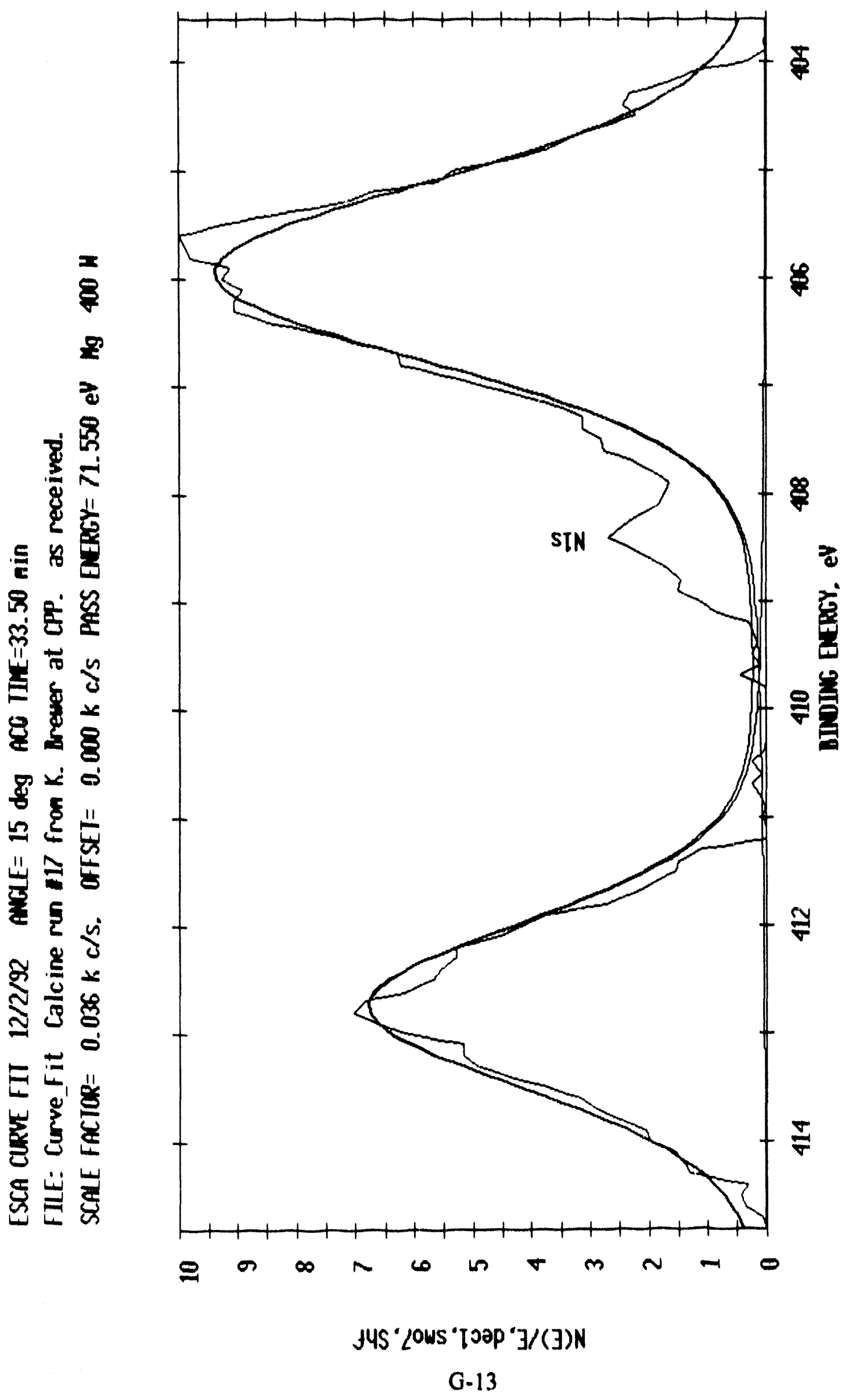




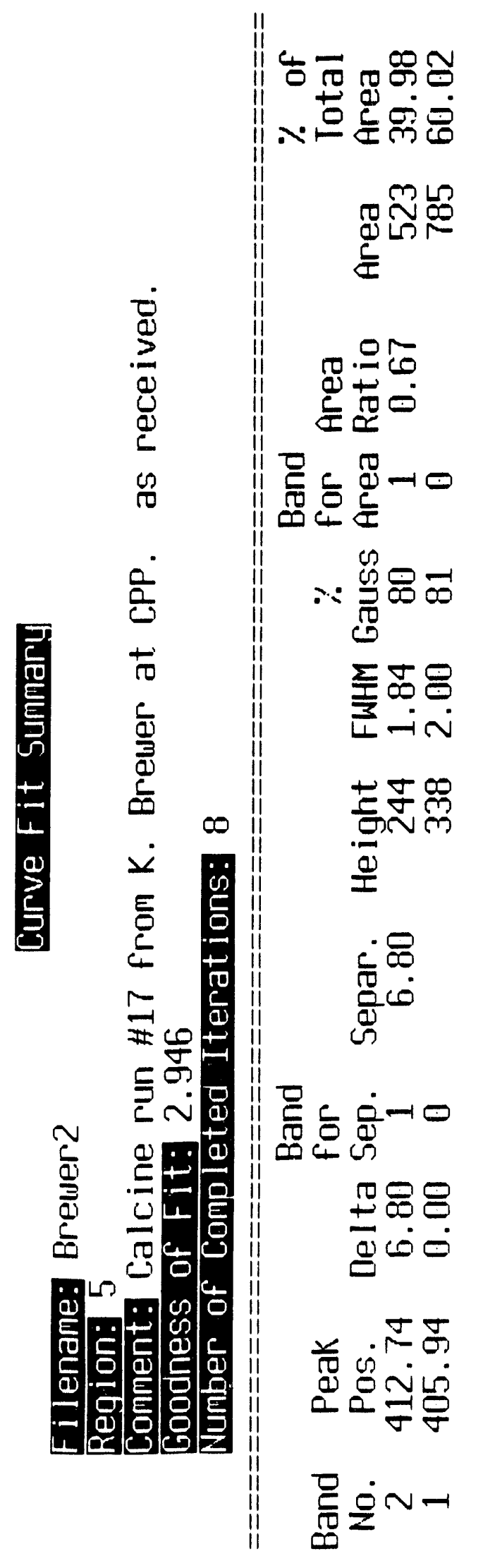




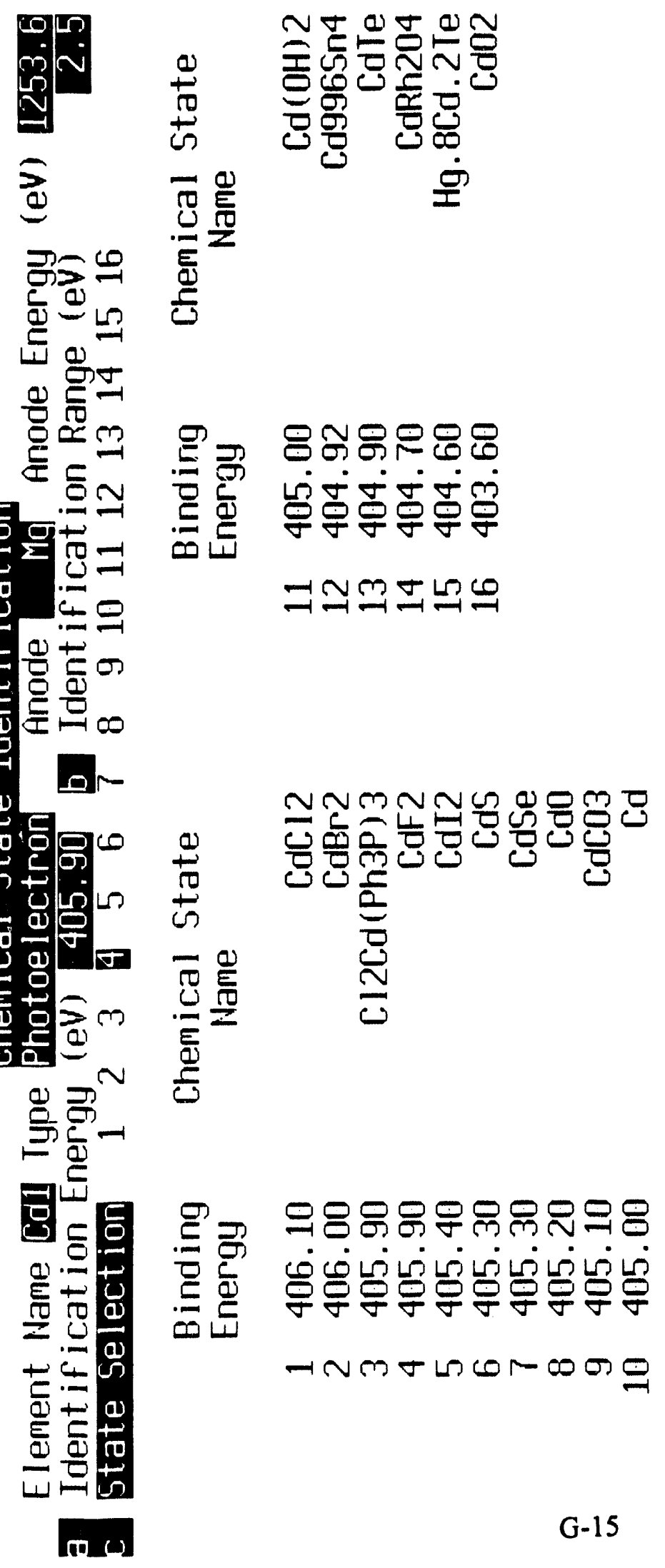




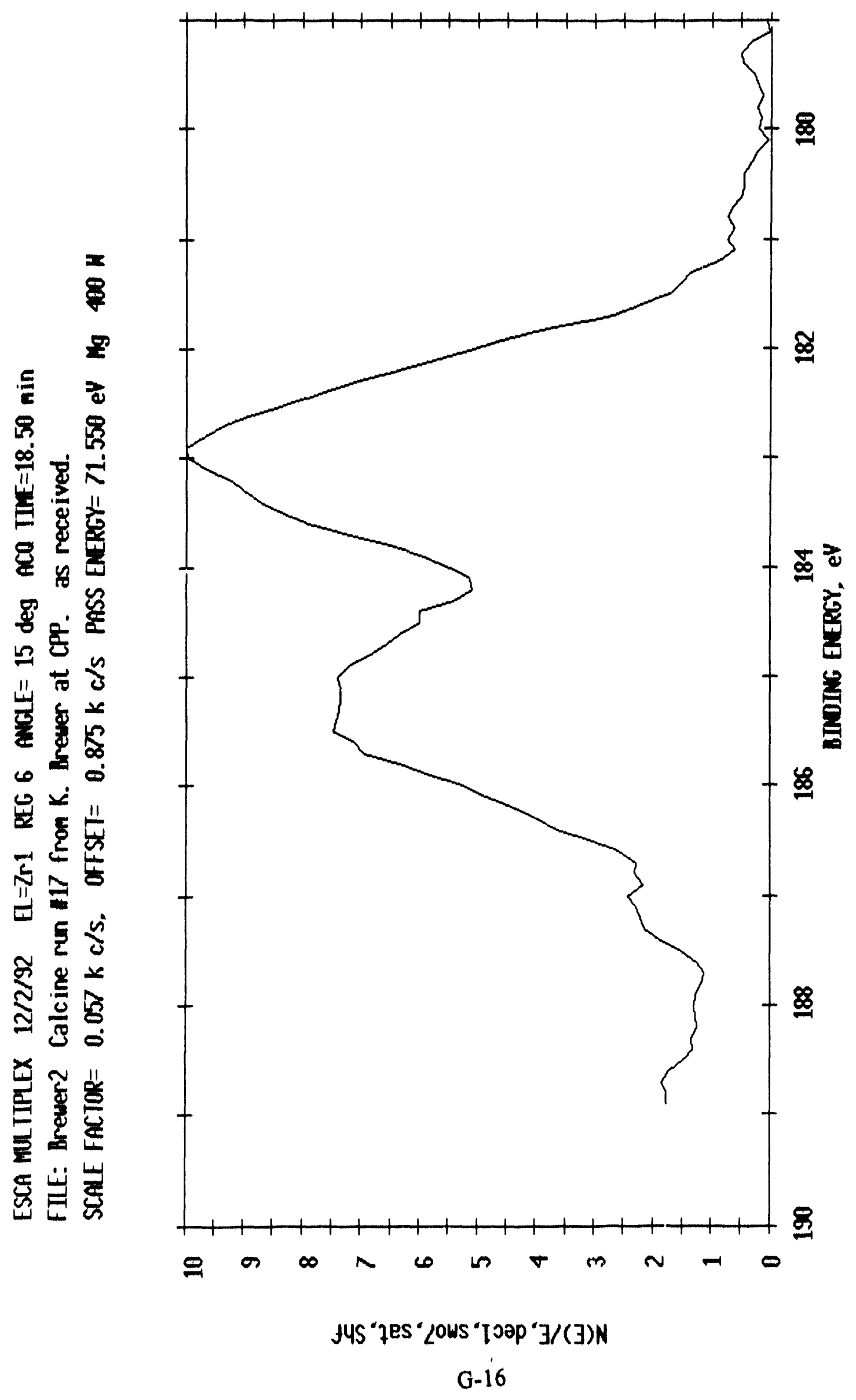




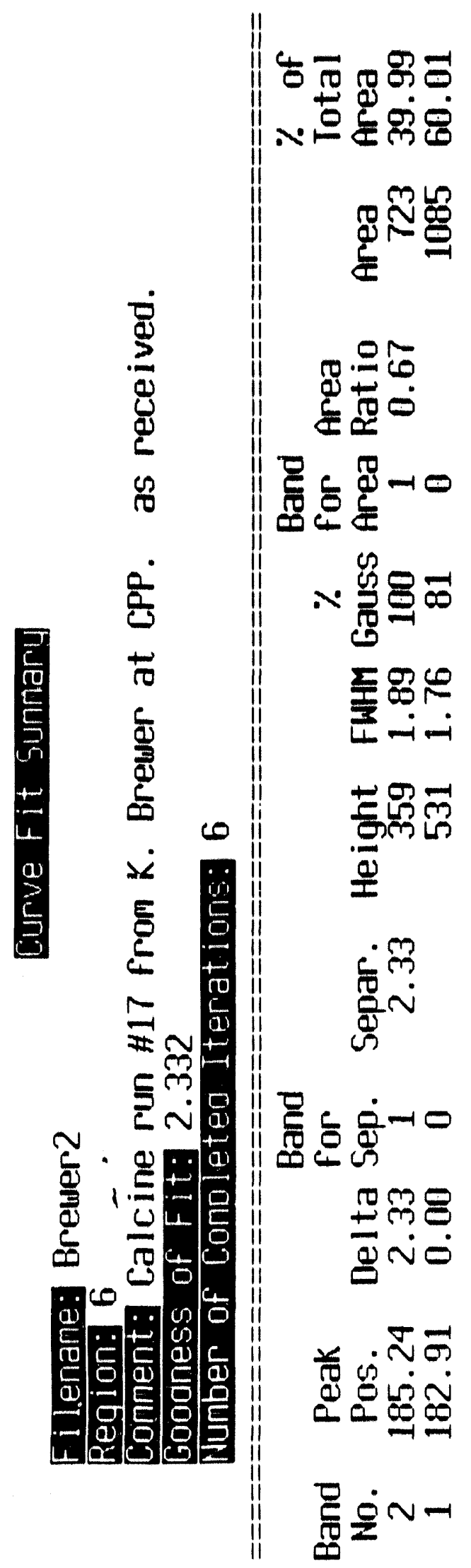




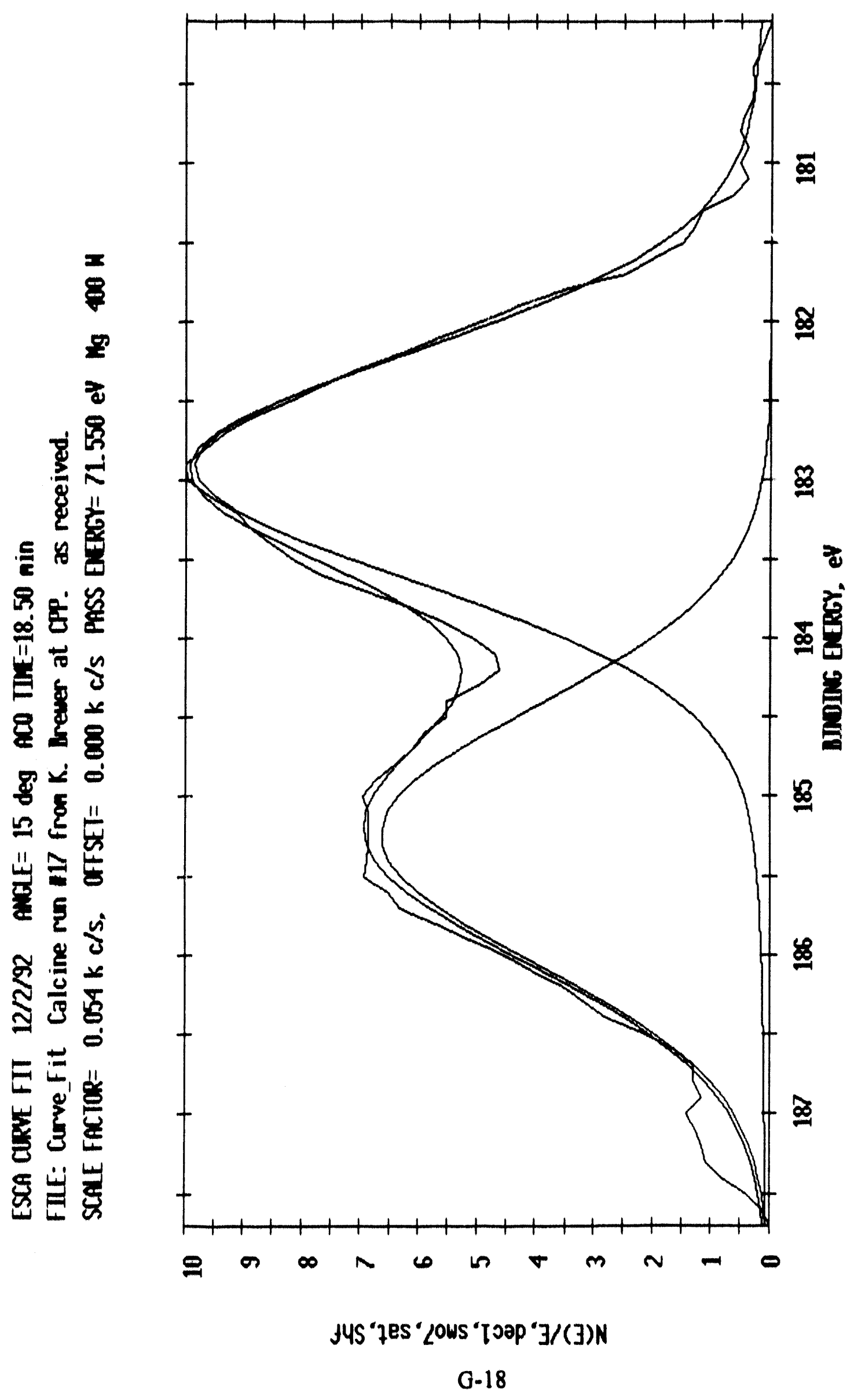




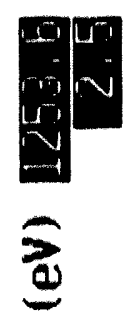

$$
i
$$

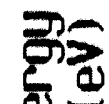

a

告

을

5

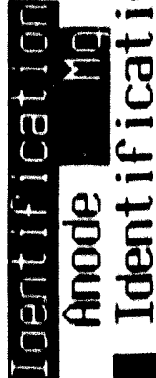

EN

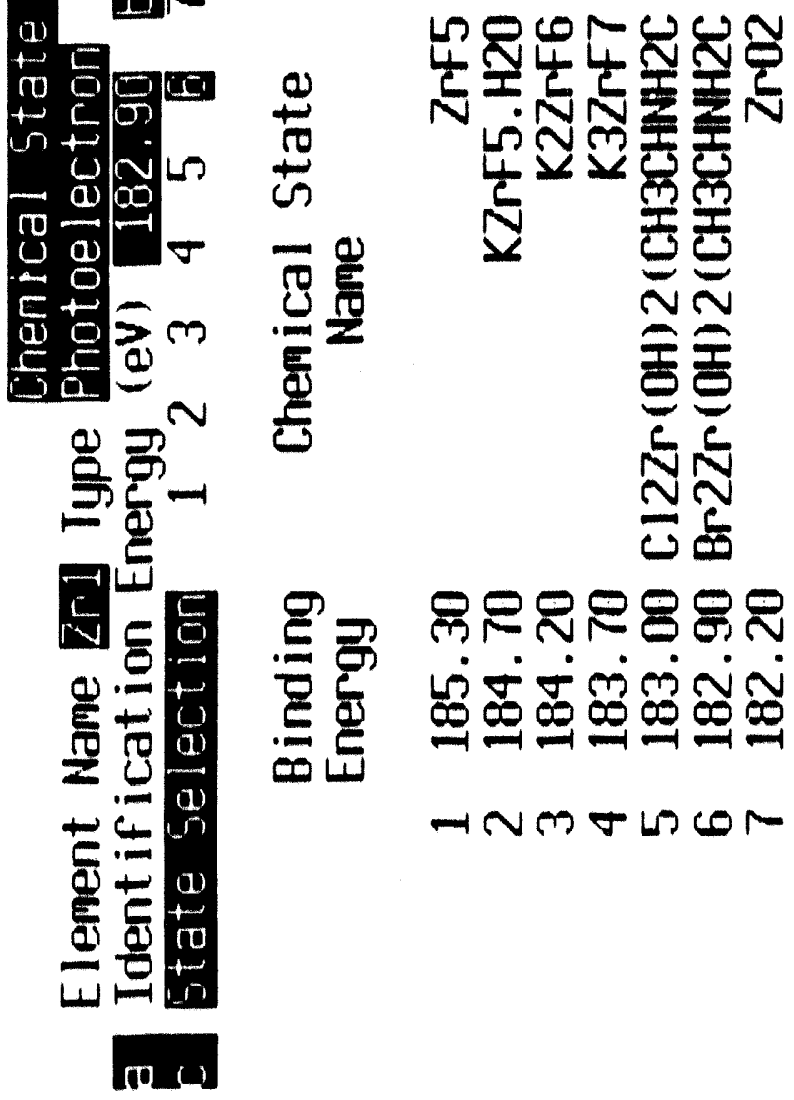




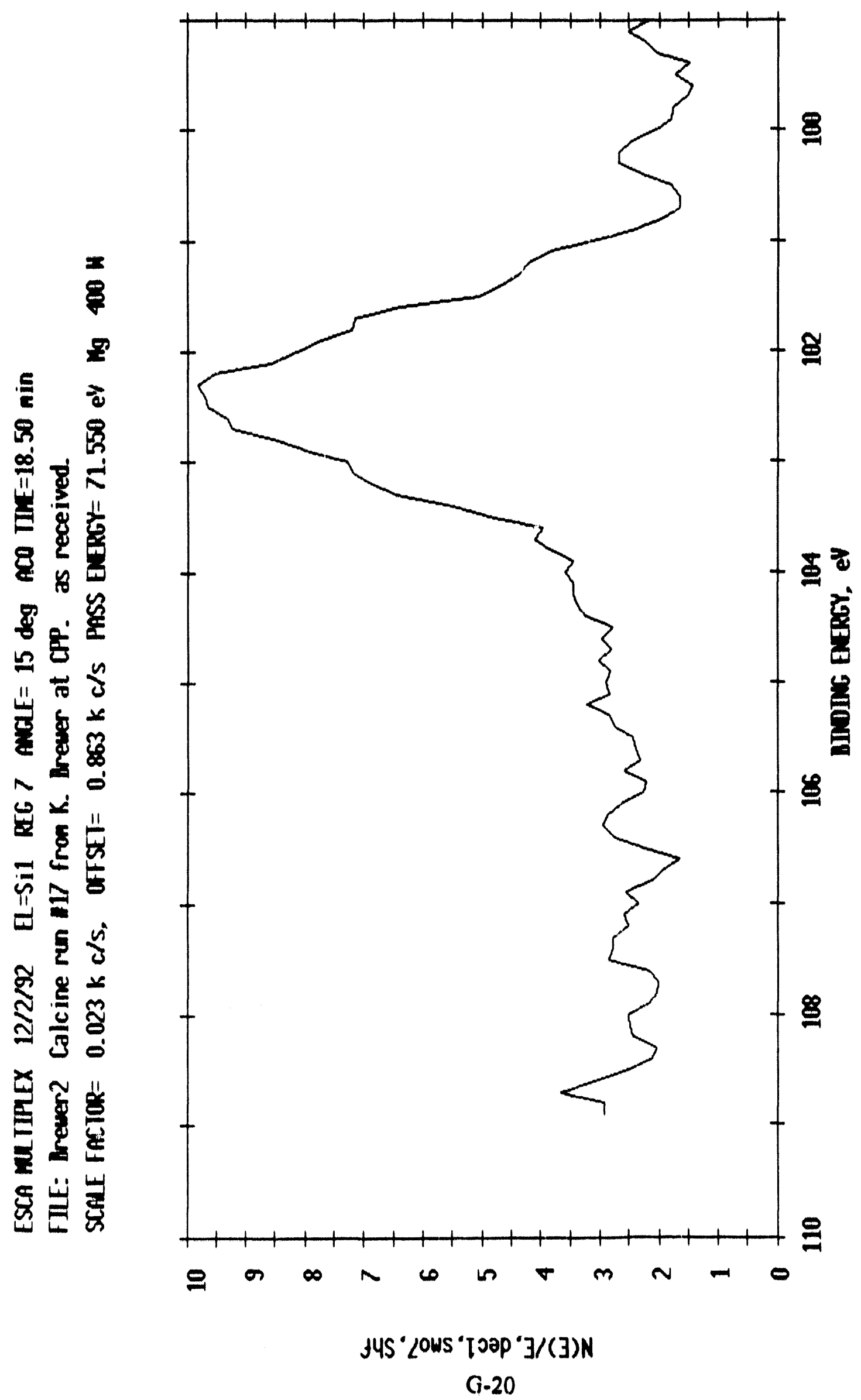




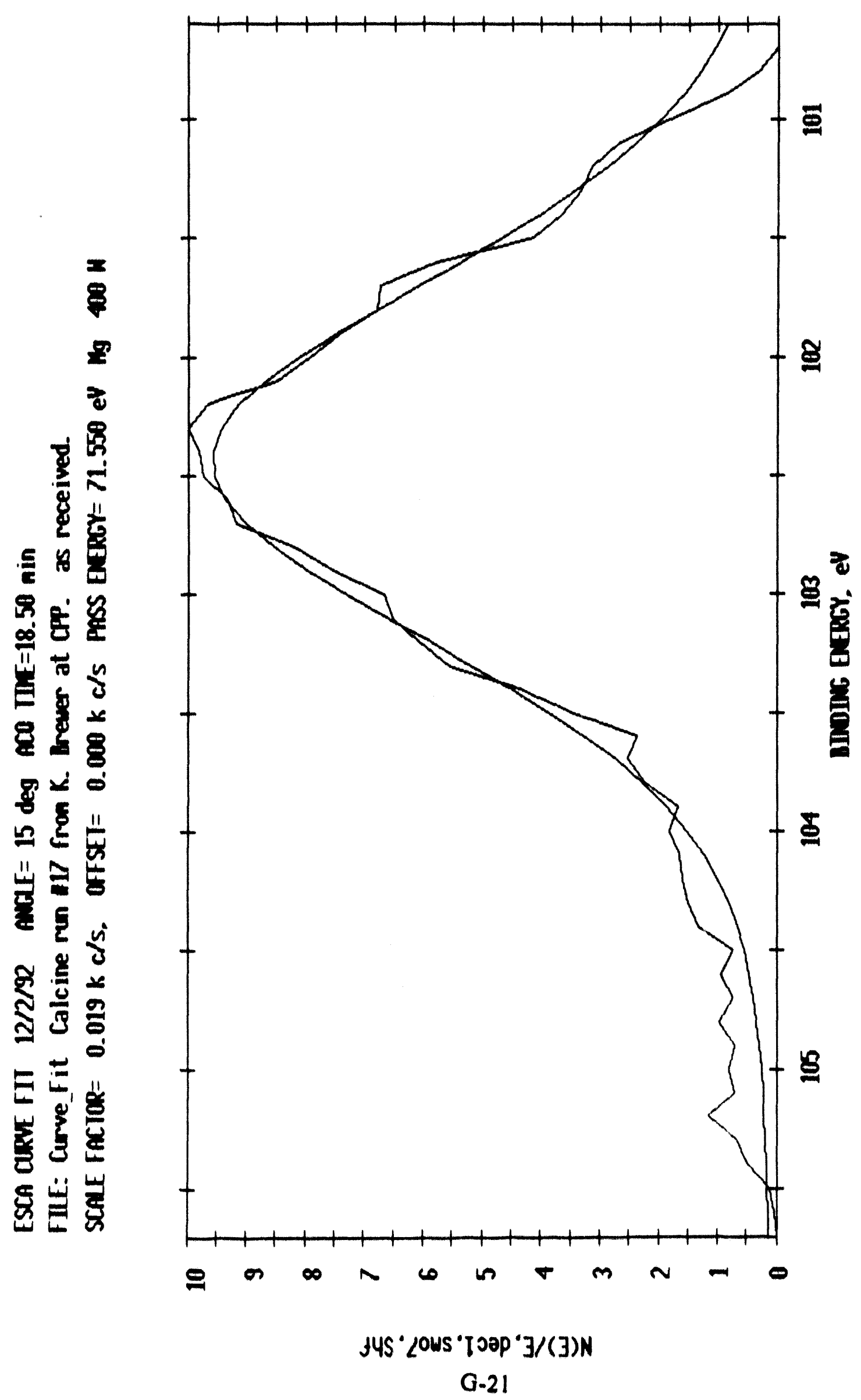




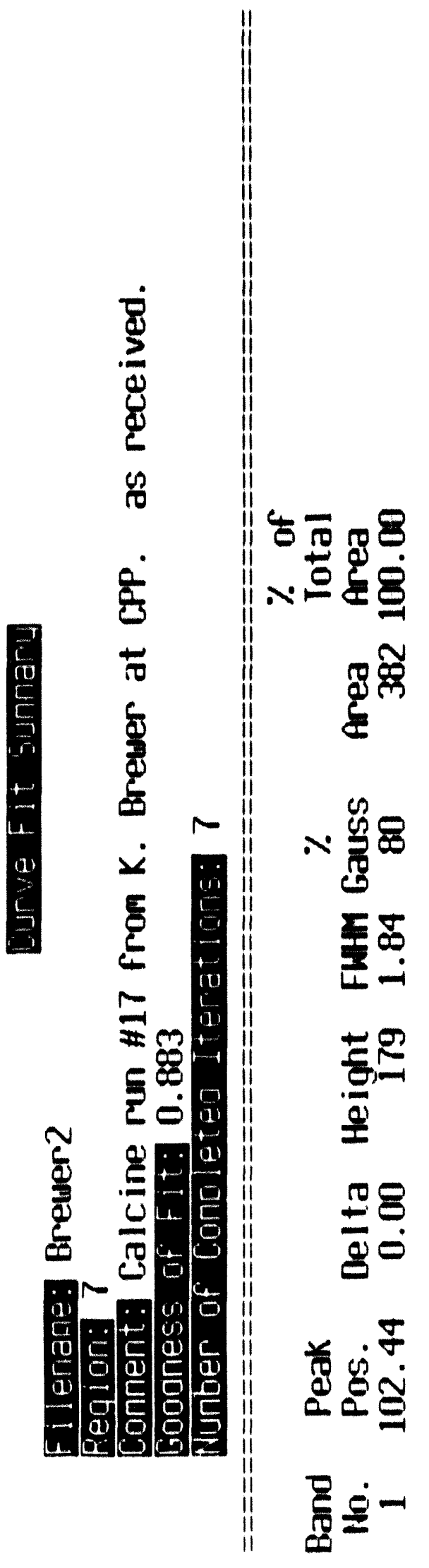




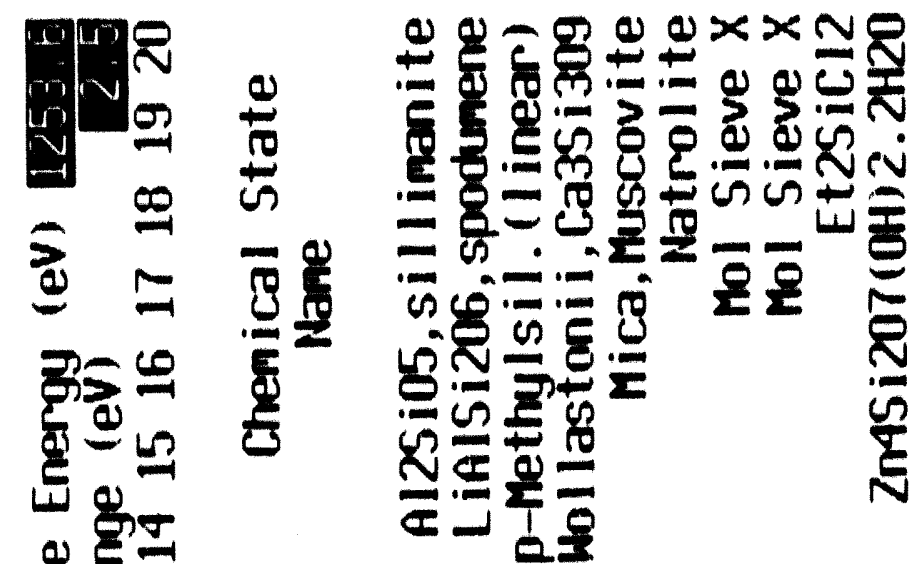

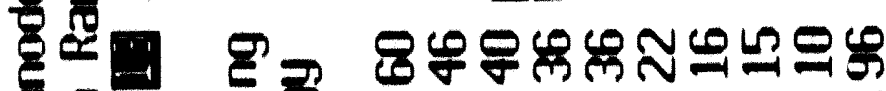
$\varepsilon_{2}$ of

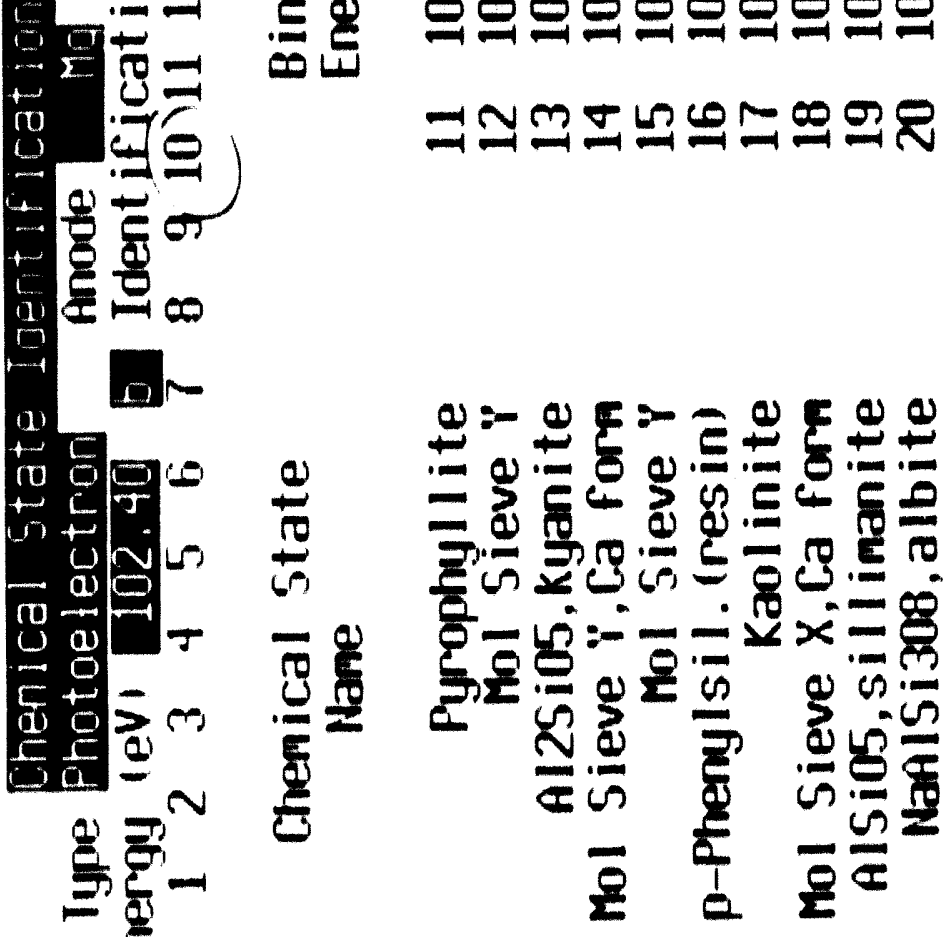

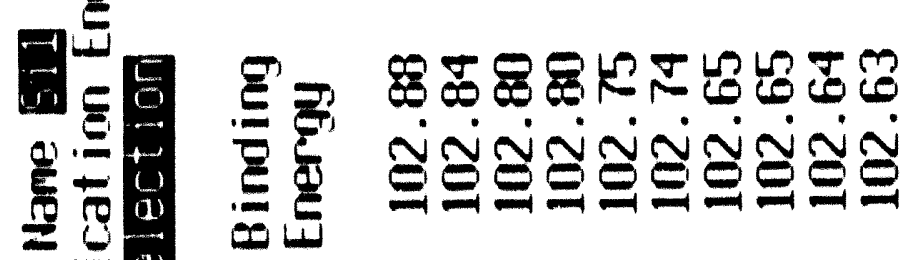

- $-n$

- Nmtuconeme 


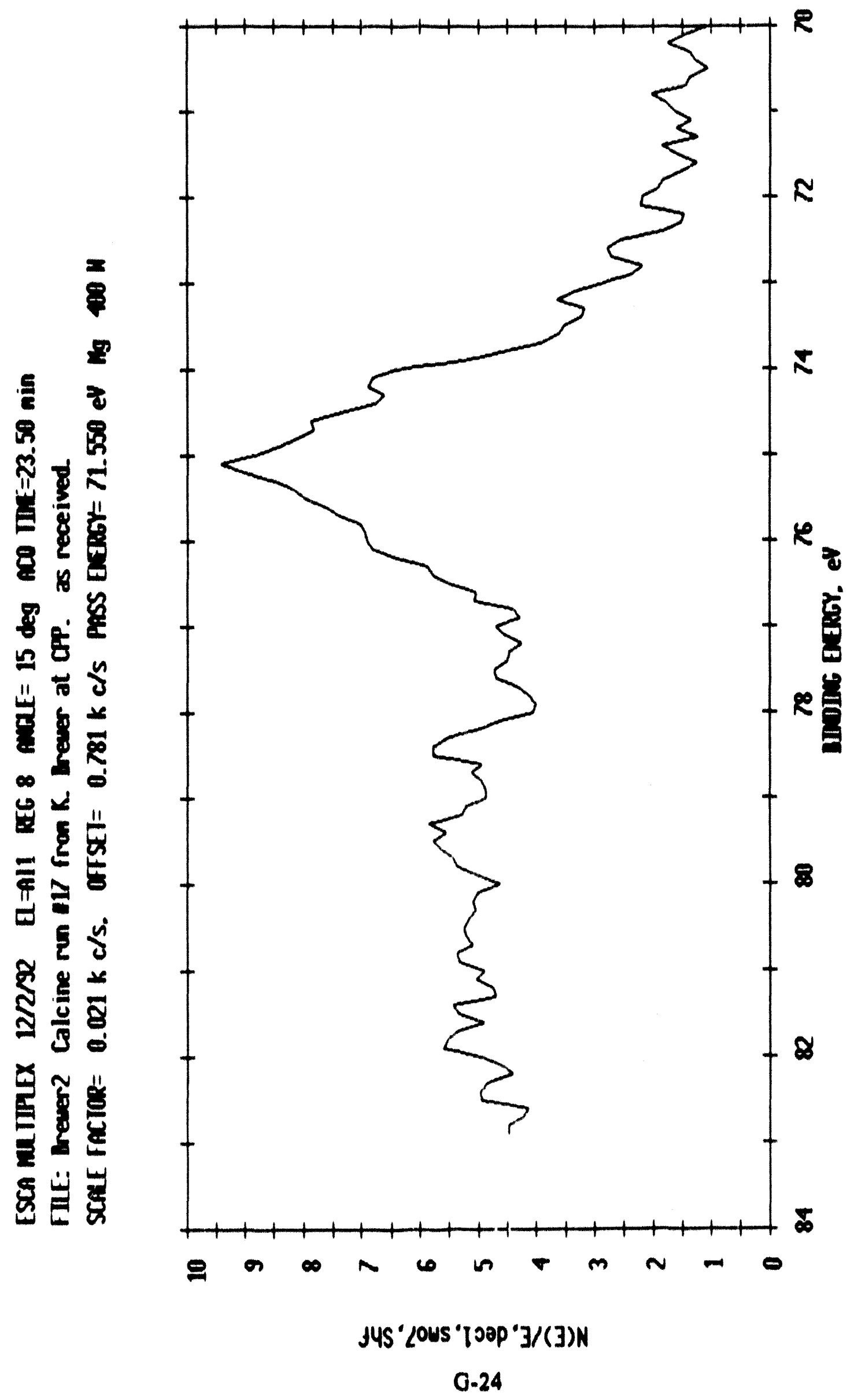




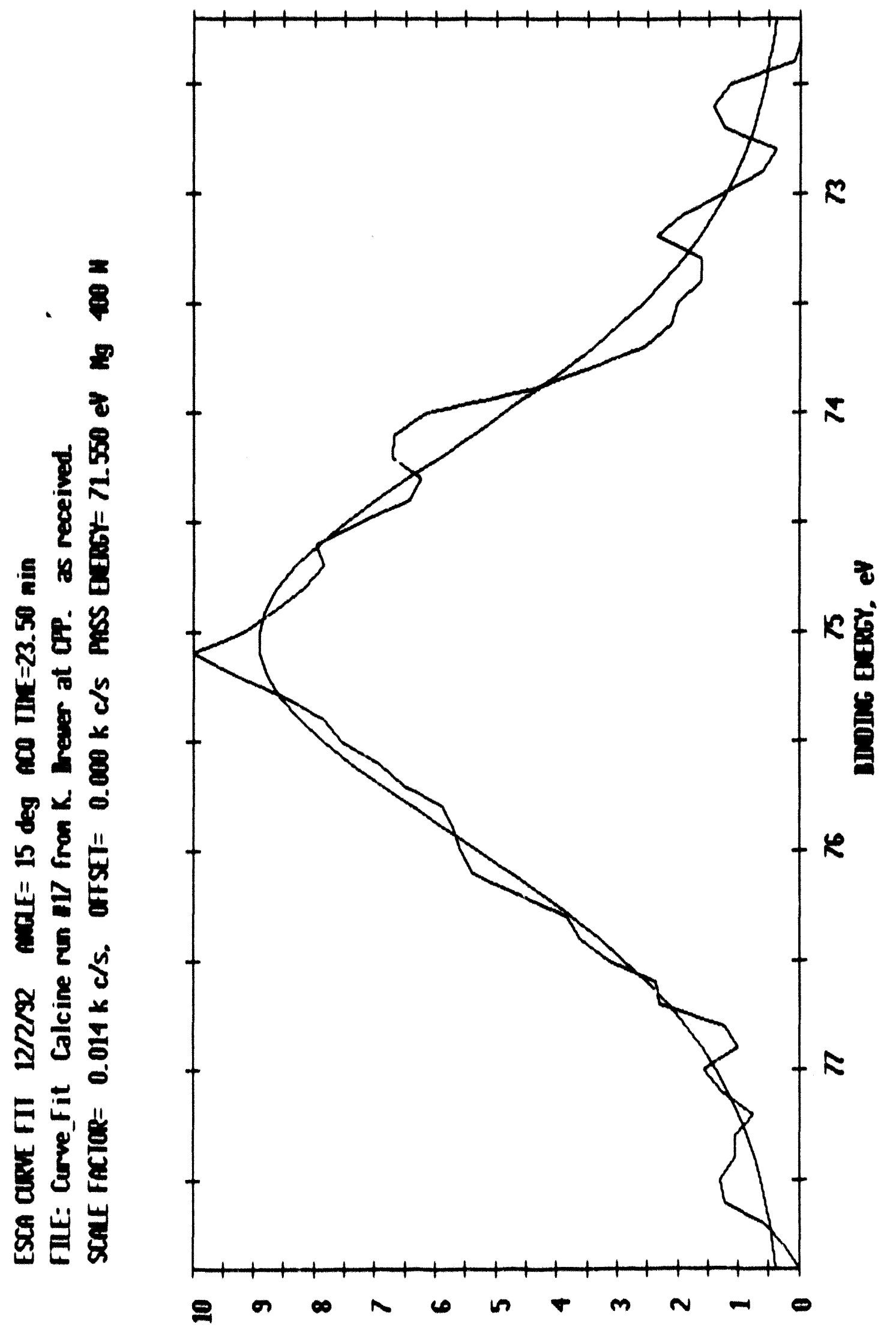

J4S L LOWS $\left[2000^{\circ} \exists /(3) N\right.$ 


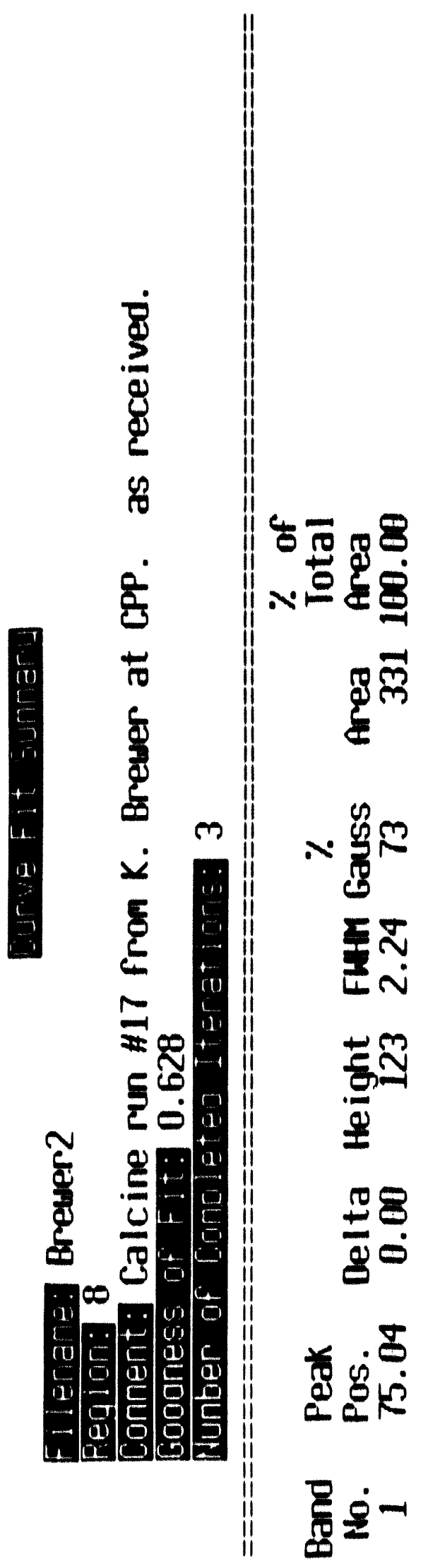




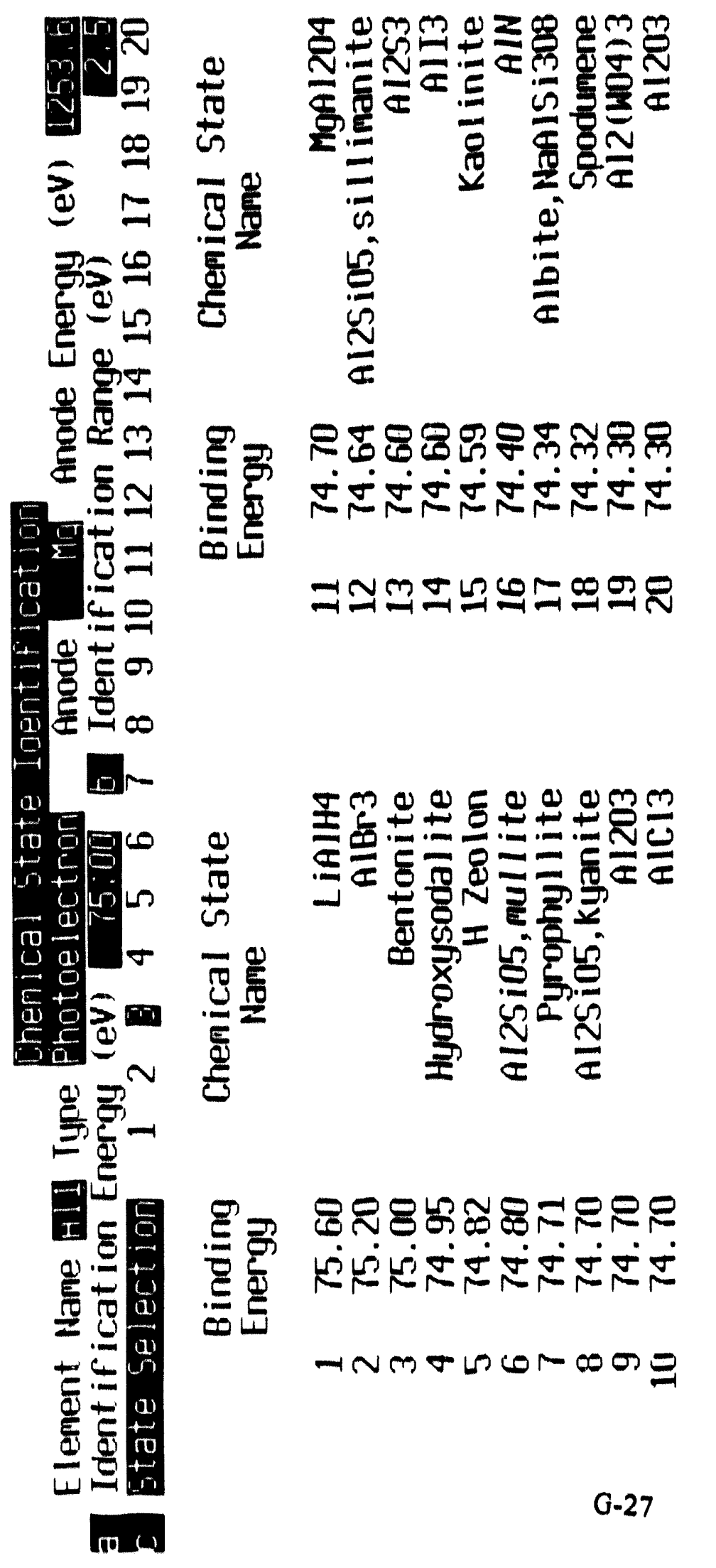




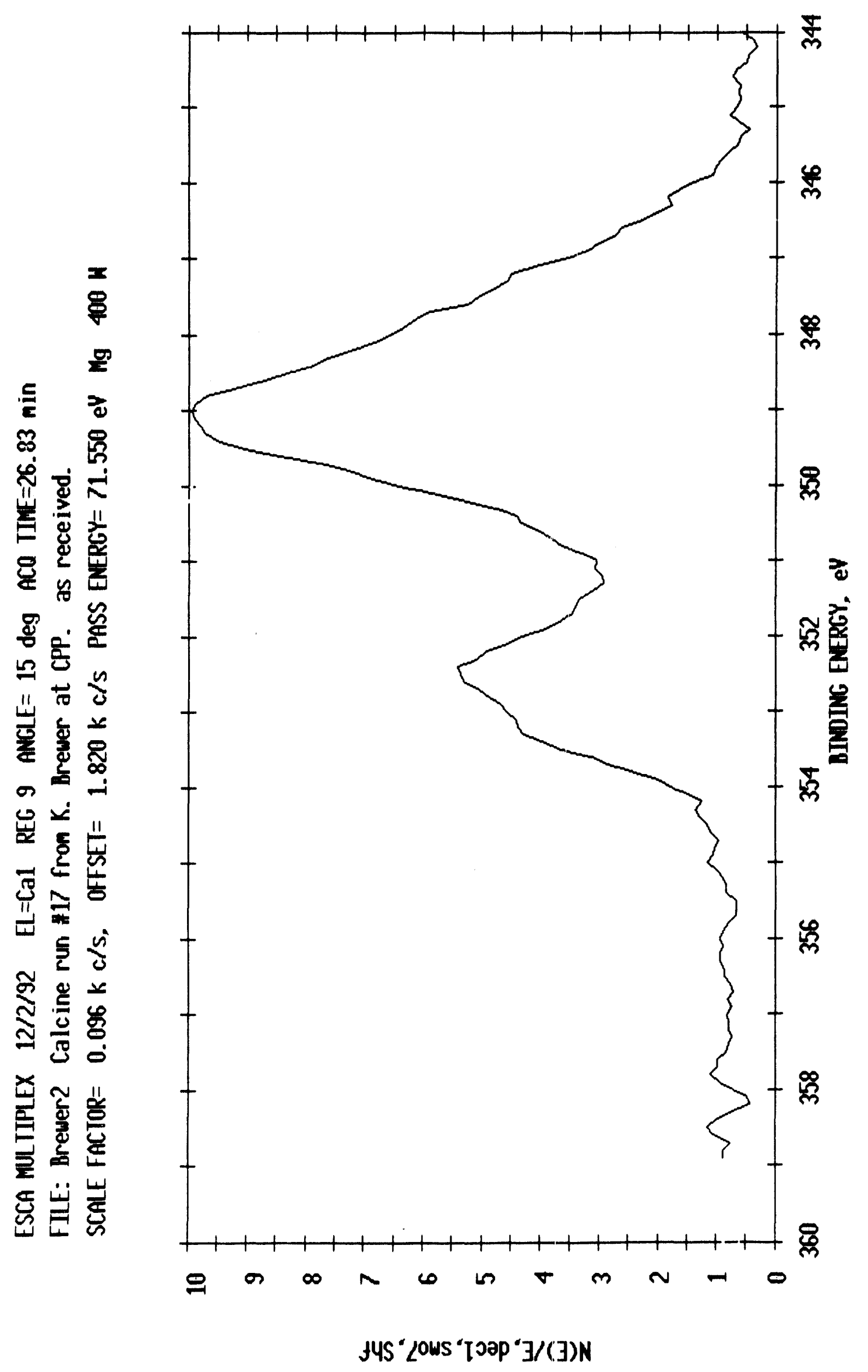

G-28 


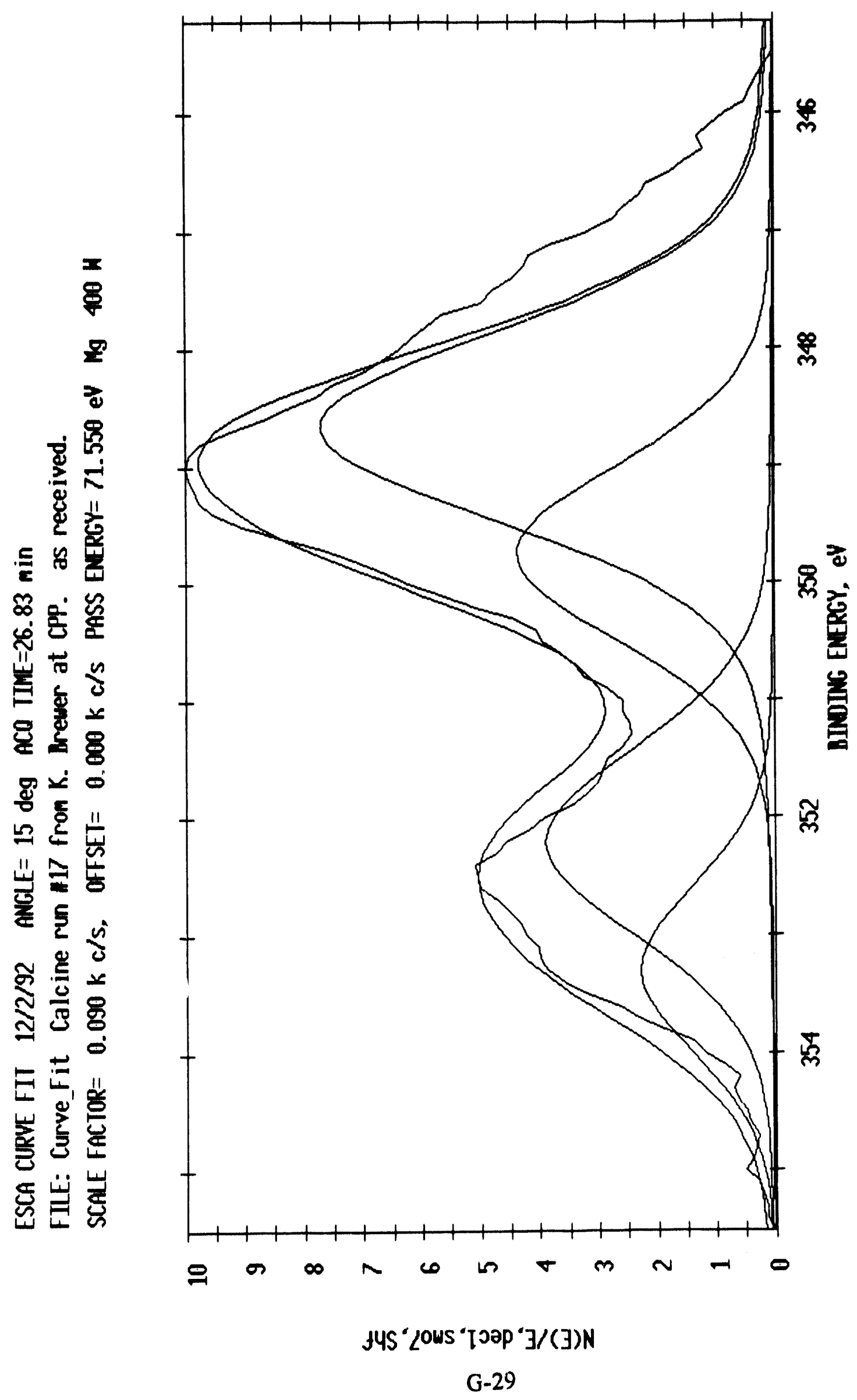




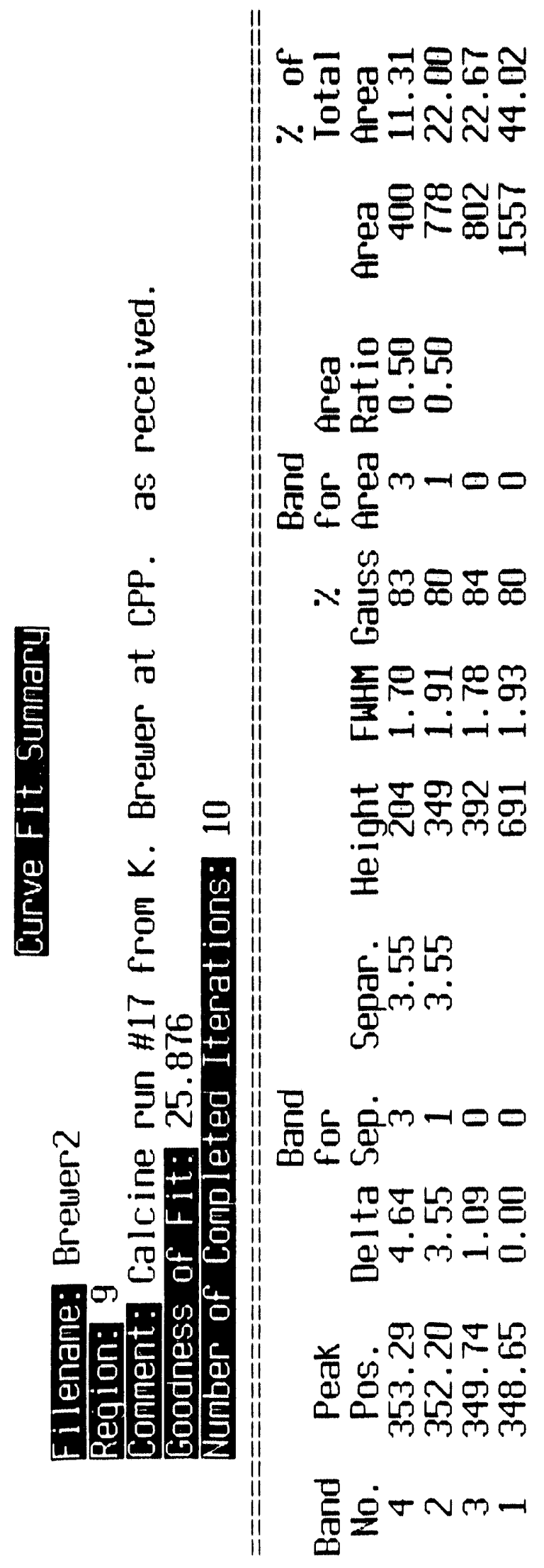




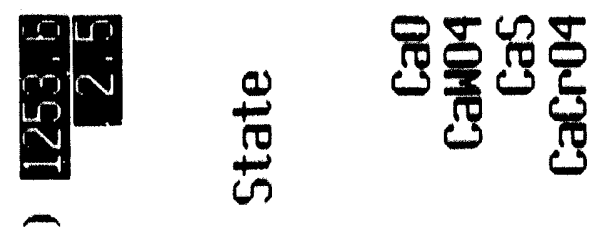

ఫ

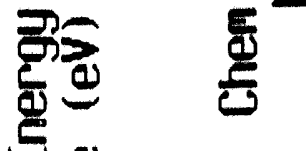

닐 a

a)

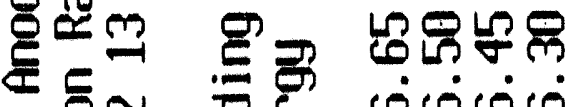

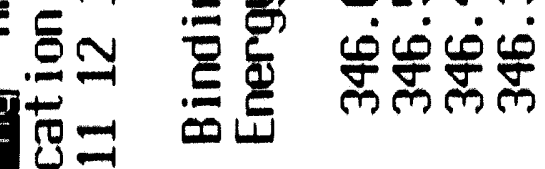

$-\Sigma$

$=\underset{-1}{-1}$

a

8 व

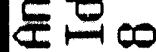

ar

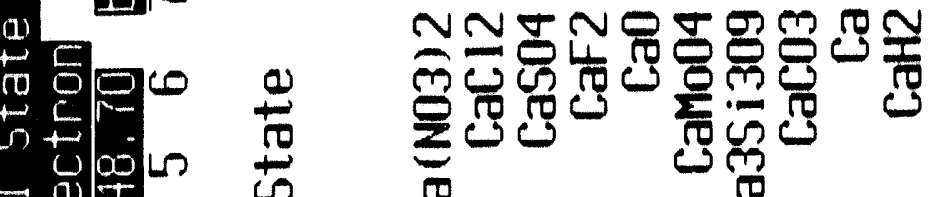

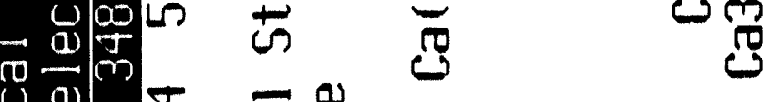

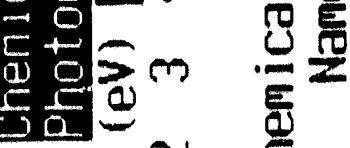

을

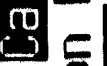

으.

Q

ขึ

$\geq 0$

$+4$

a

E $5+$

ब

뜬

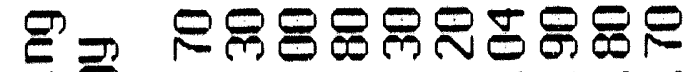

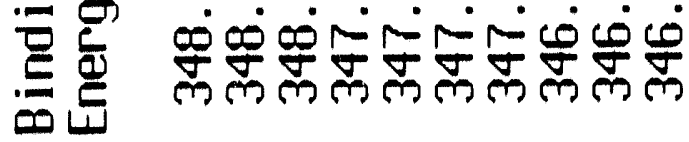

HNORLCOR 


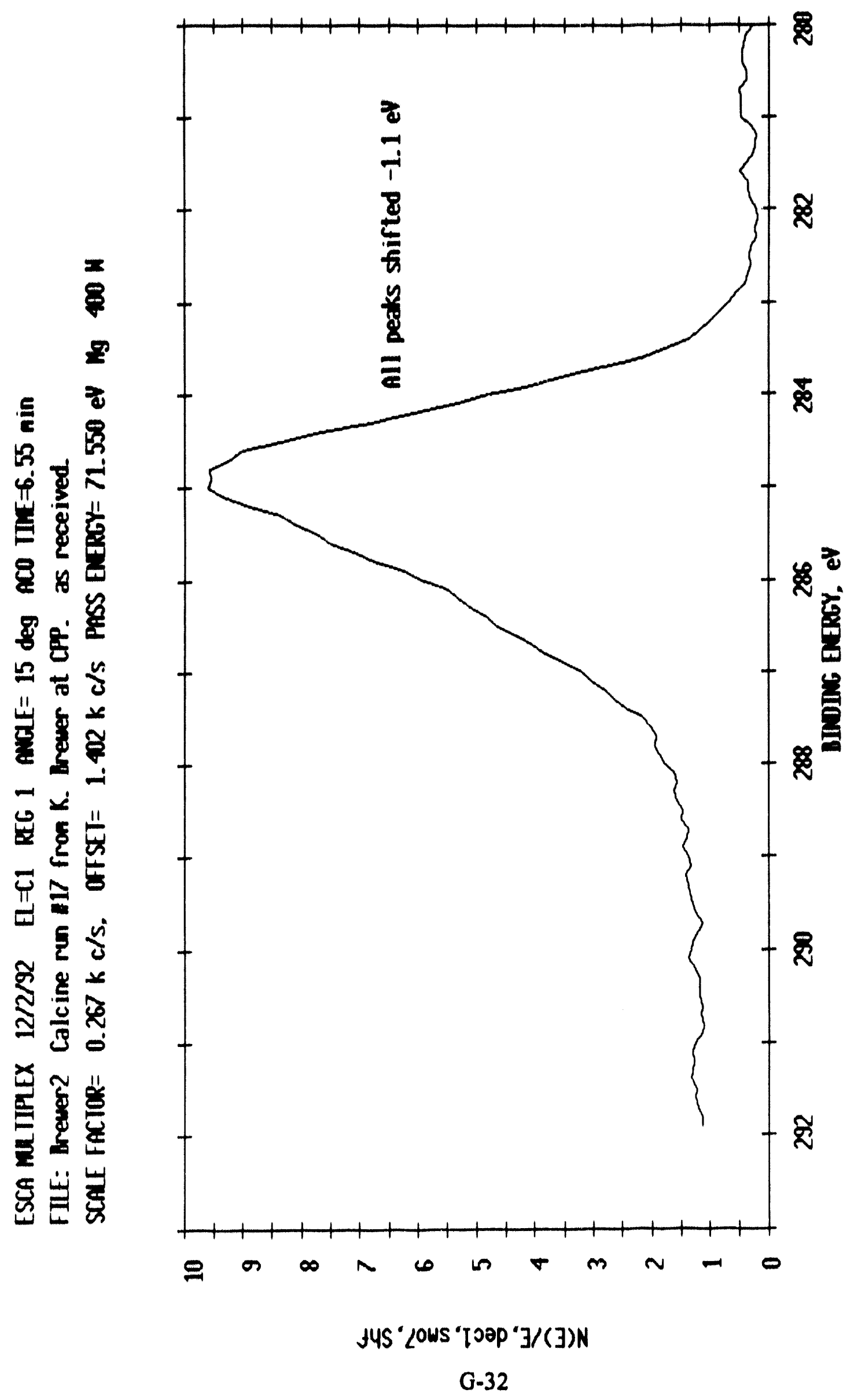




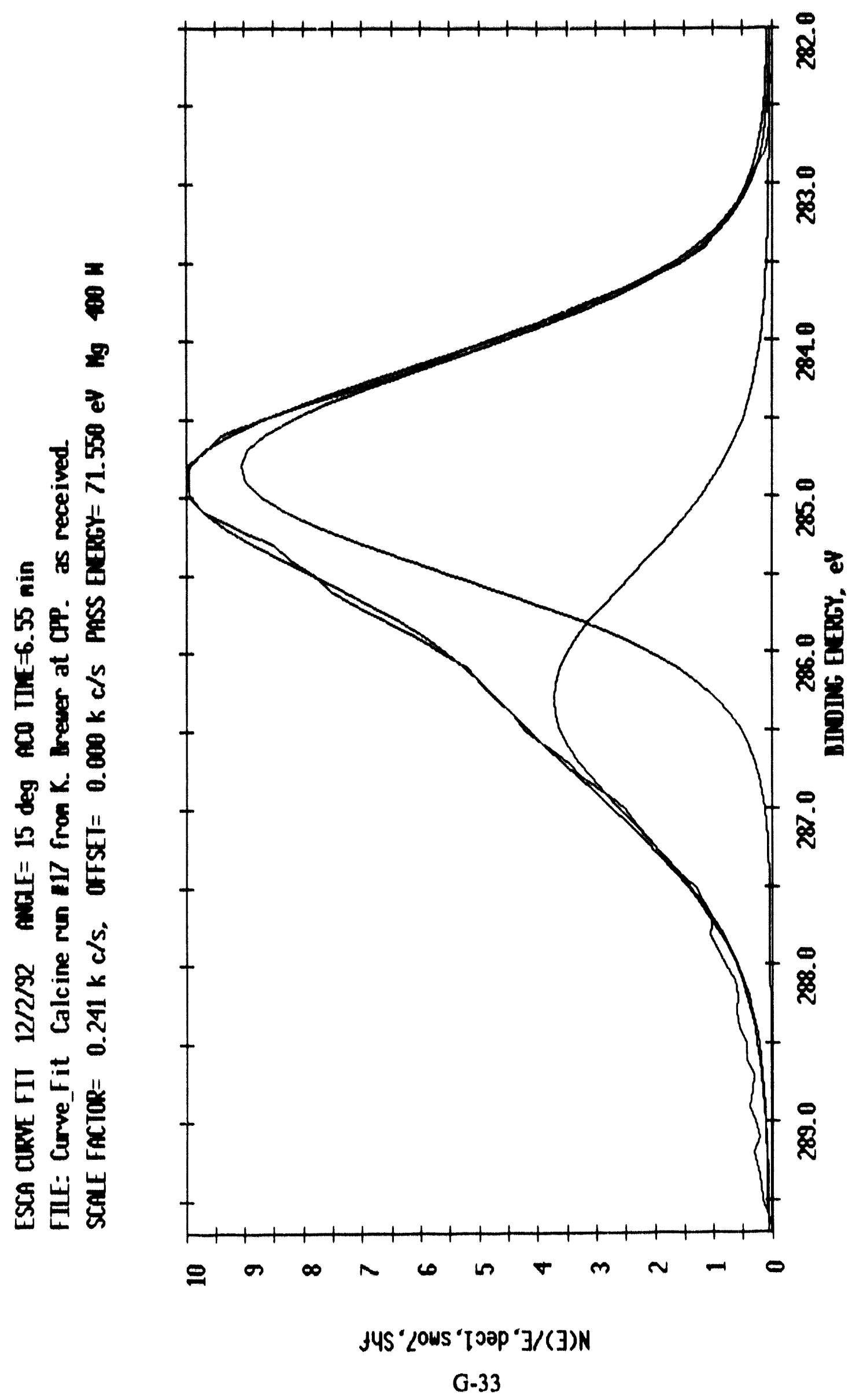




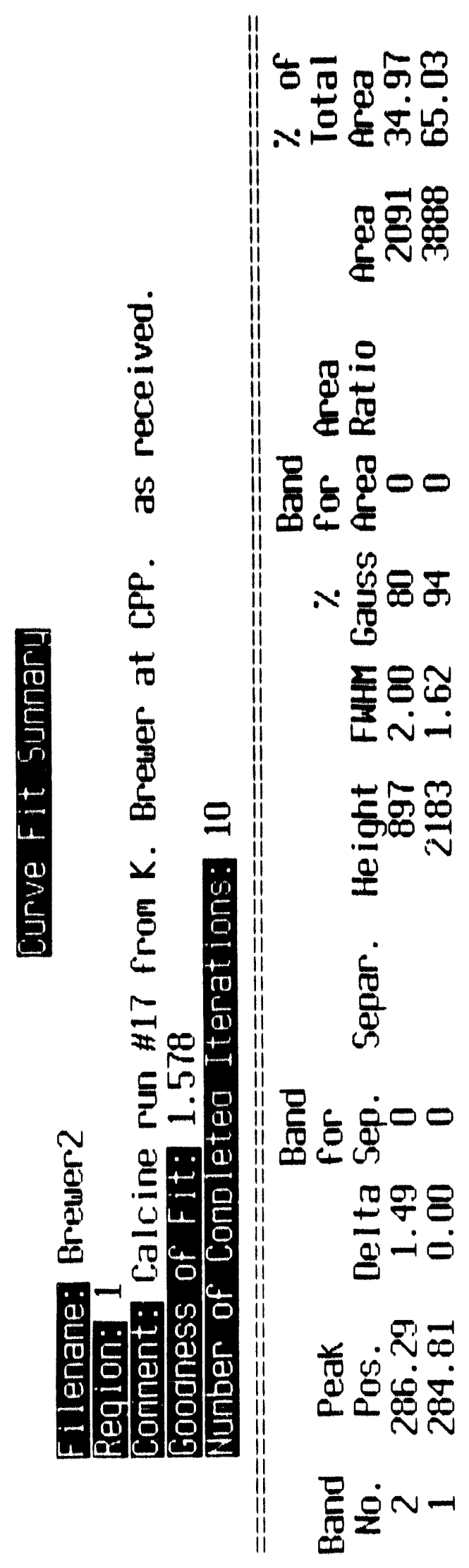




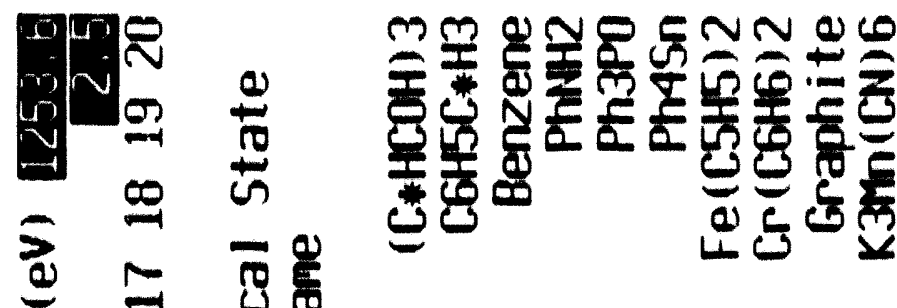

(2) $\equiv$ 舟需

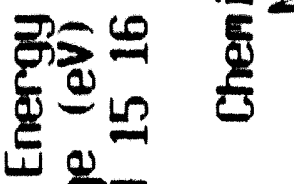

용 툴

틀

동

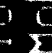

$28 \ldots$

e

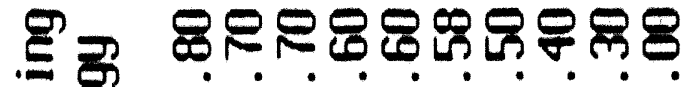

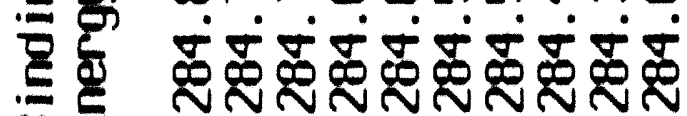

-

$0+$

둥

을 은

프

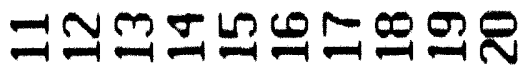

a) $D$

तo

Gc

in

- a

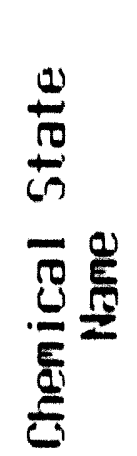

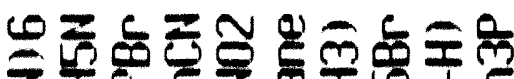

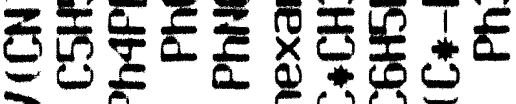

כ

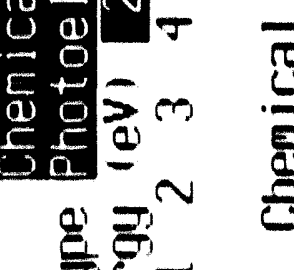

힘

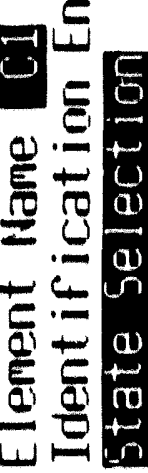

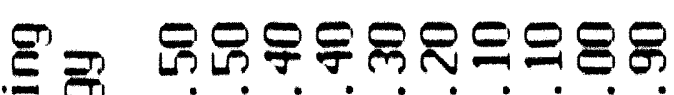

.

幽

TNMTLCOR

(n) 


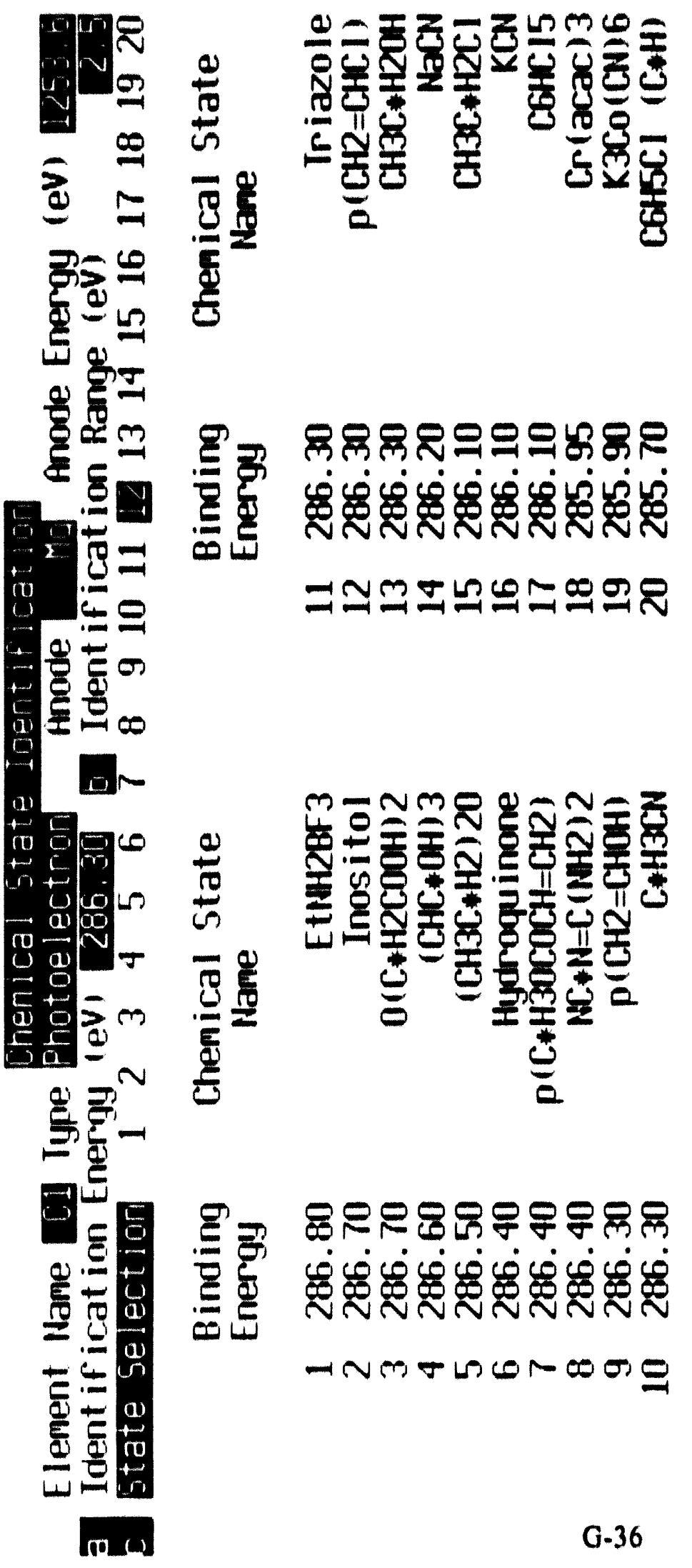




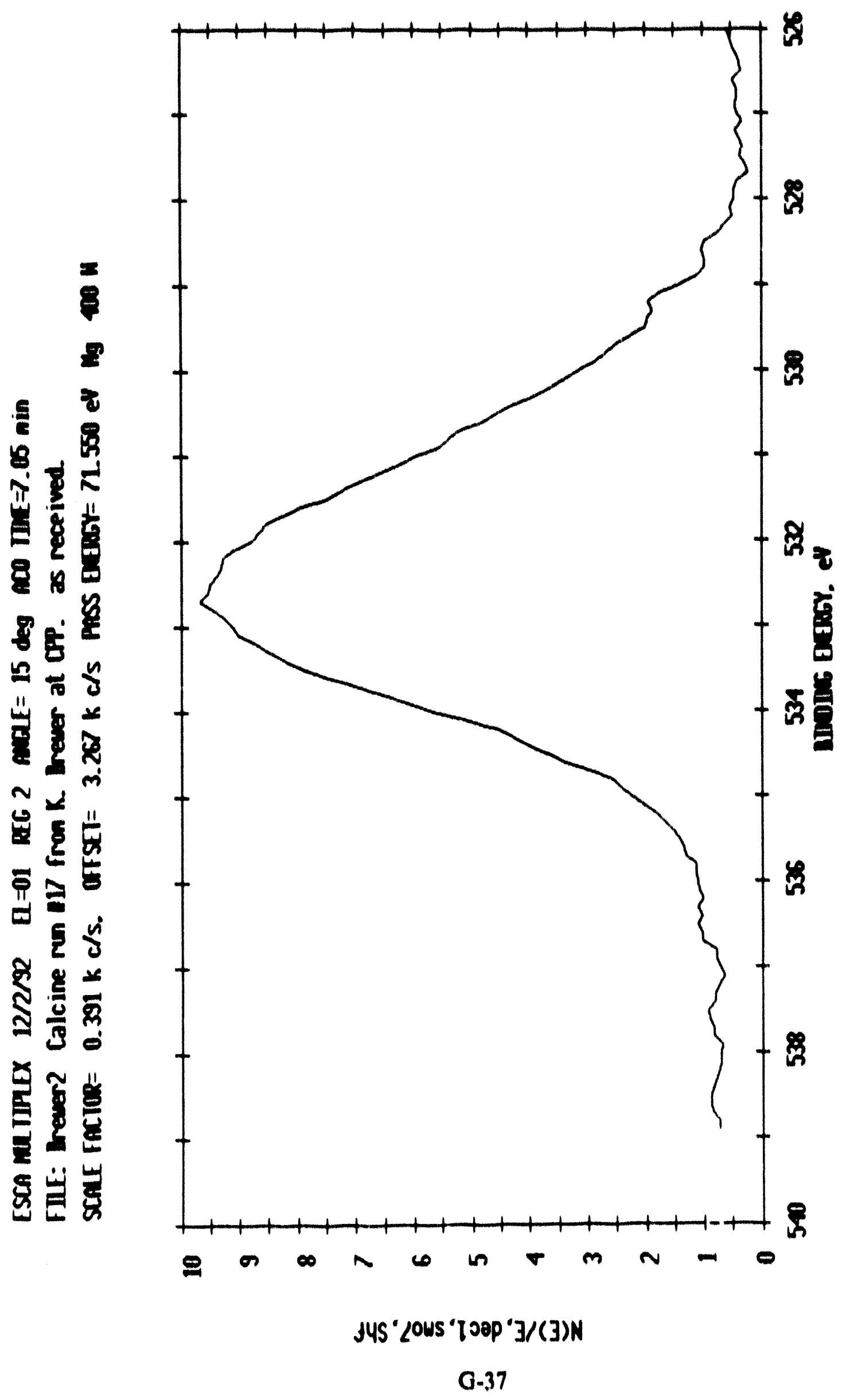




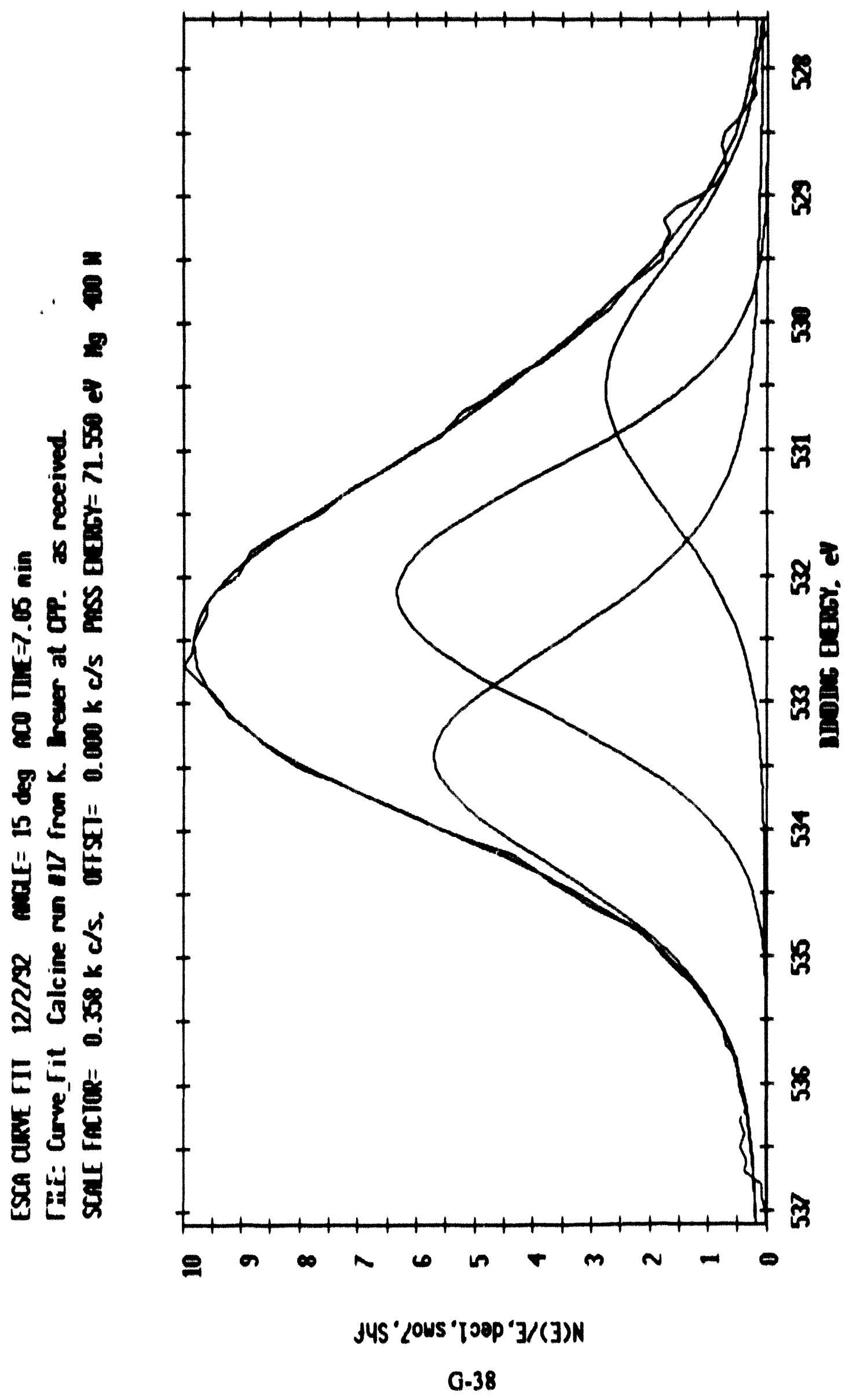




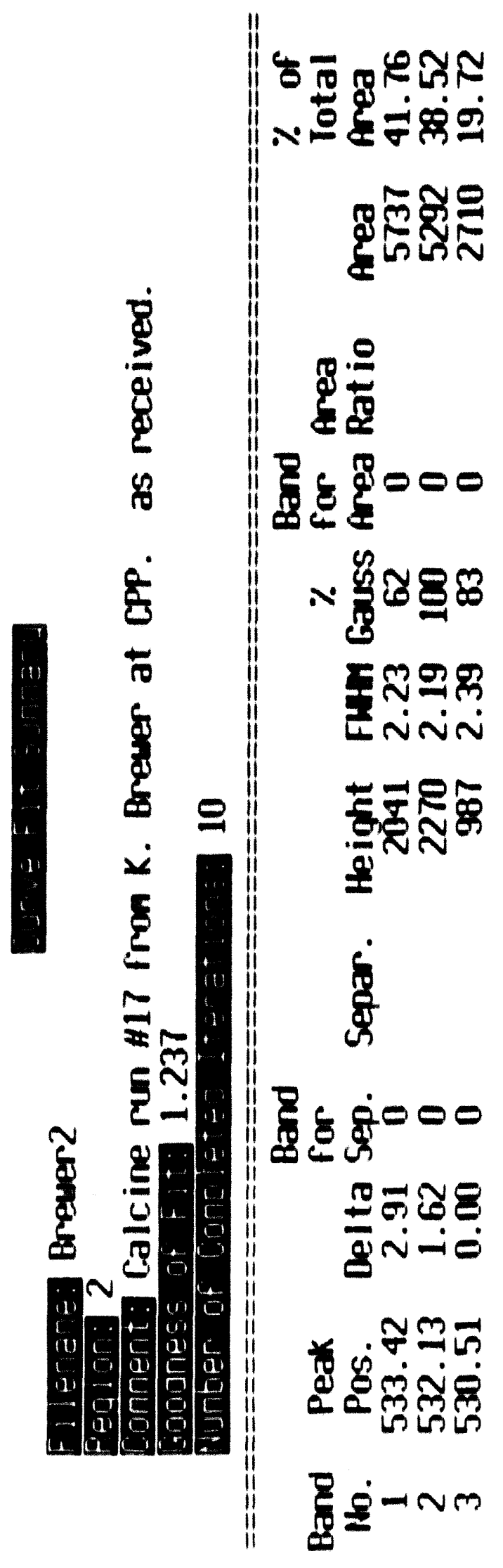




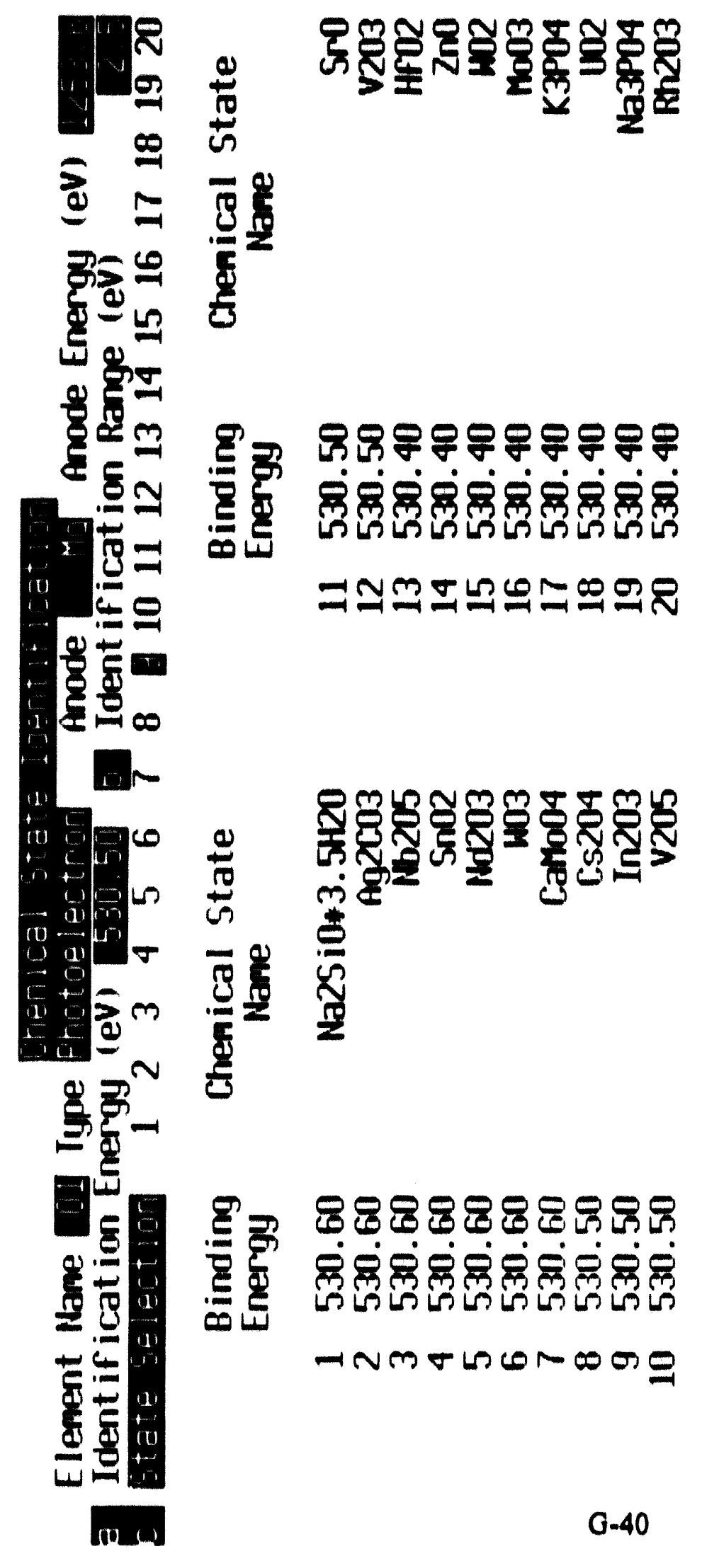




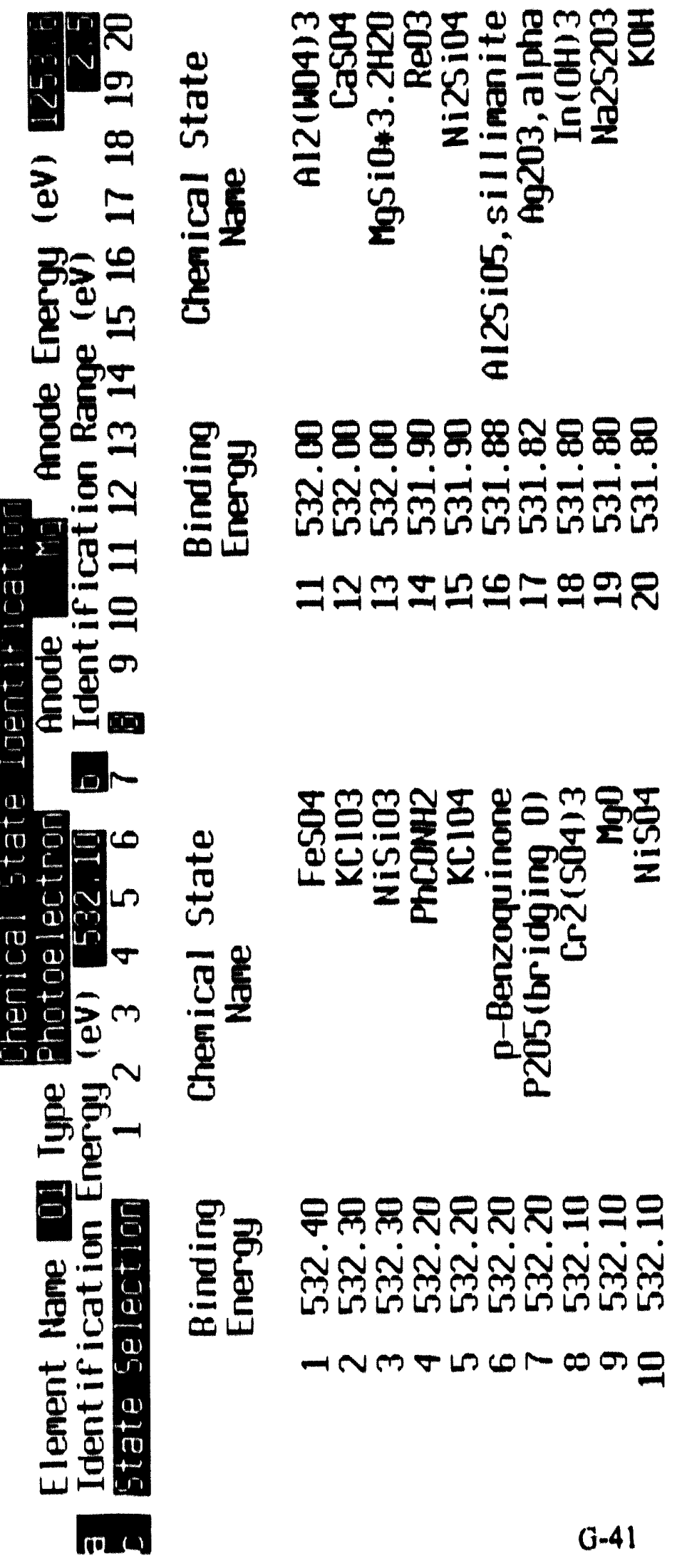




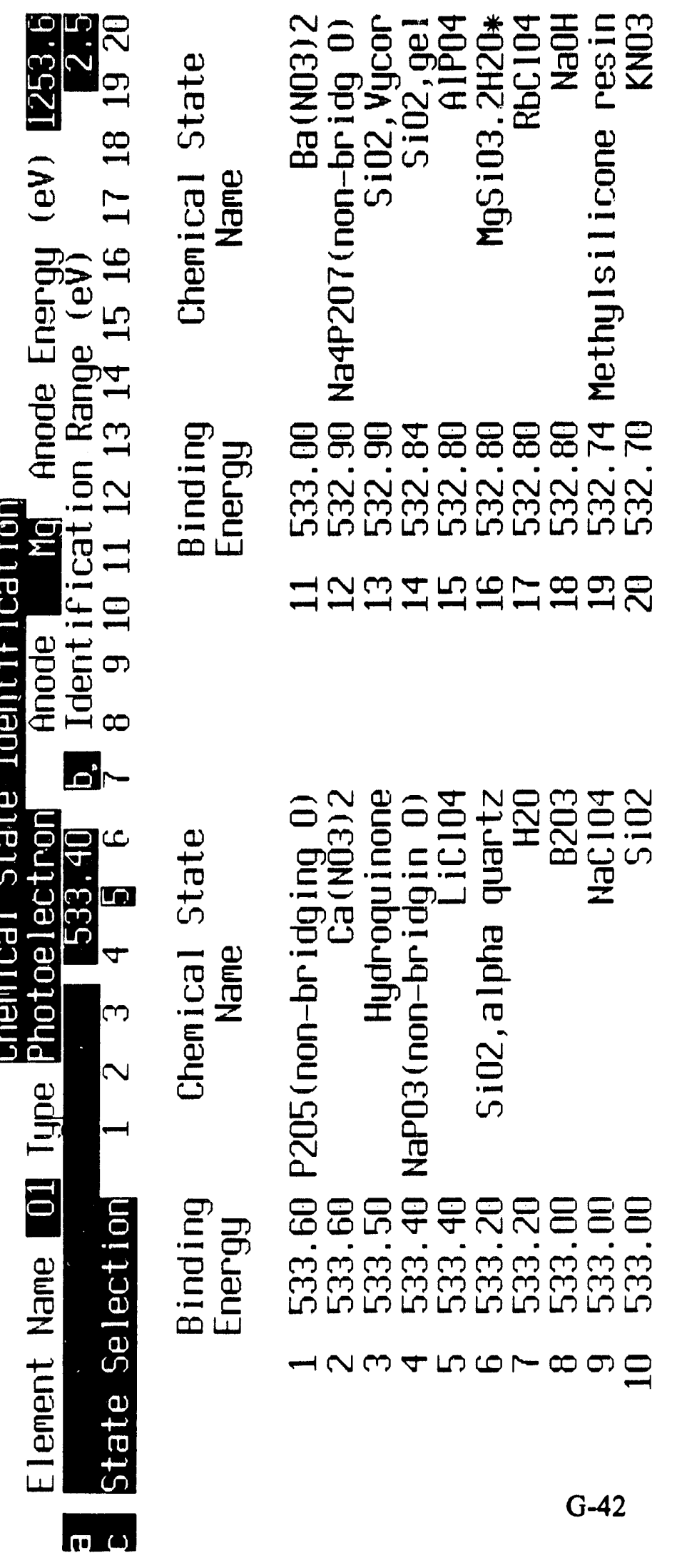


Appondix $\mathrm{H}$

$F * A * C * T$ EQUILIB Results

H-1 
The following pages contain all of the output generated by the F*A*C*T EQUILIB code. It is operated as follows: (1) the reactants are specified, (2) the temperature and pressure are specifled, (3) the species, solutions, and/or pheses to be considered in the free energy minimization calculation are specified from the database listing, and (4) the free energy minimization is performed.

**** ENTER REACTANTS (/H)

OR PRESS <RETURN> FOR

$55.405 \mathrm{H2O}+4.558 \mathrm{~N}^{*} 03+.01 \mathrm{CL}+.046 \mathrm{~S}+.09202+1.648 \mathrm{H}+.081 \mathrm{CD}+.338 \mathrm{NA}+$

CONTINUE THE REACTION

$1.709 \mathrm{~F}+1.055 \mathrm{CA}+.14 \mathrm{~B}+.393 \mathrm{AL}+.2332 \mathrm{R}+$

CONTINUE THE REACTION

$13.102+52.4 N 2+2.1 C+4.2 H=$

ENTER FINAL STATES (/H)

OR PRESS 〈RETURN> FOR

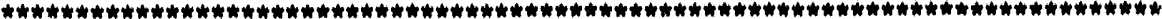

$T$ PROD P PROD $V$ PROD DELTA H DELTA $V$ DELTA G DELTA $S$ DELTA U DELTA A

(K) (ATM) (L) $2 \ldots .$. requires "TH" opt ion from OPTION MENU .......

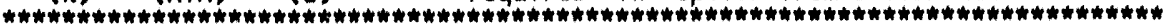
773. 1 .

1 - 338 GASES

339 - 451 LIQUIDS

452 - 640 AQUEOUS

641 - 830 SOLIDS

831 - 832 SOLN-SLAG slag - Quasichemical model for molten oxides

833 - 835 SOLN-SALT salt - molten salt solution

ENTER THE CODE SELECTION (/H) (enter "LIST" to list species, "EG" for examples) OR PRESS <RETURN> FOR

list

LIST: (HELP ALL G LIQ AQ S SOLN PRIV 2-11 LOC)

ENTER LIST COMMAND (H FOR HELP)

OR PRESS <RETURN> TO CONTINUE

all

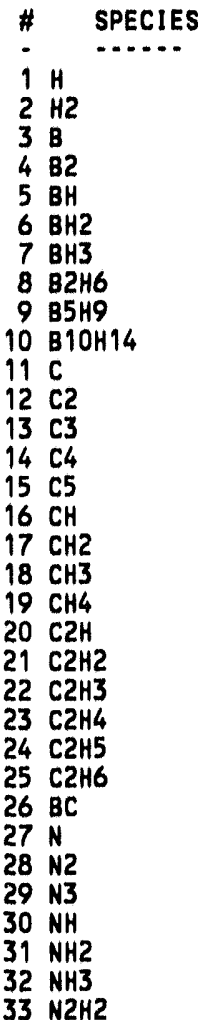

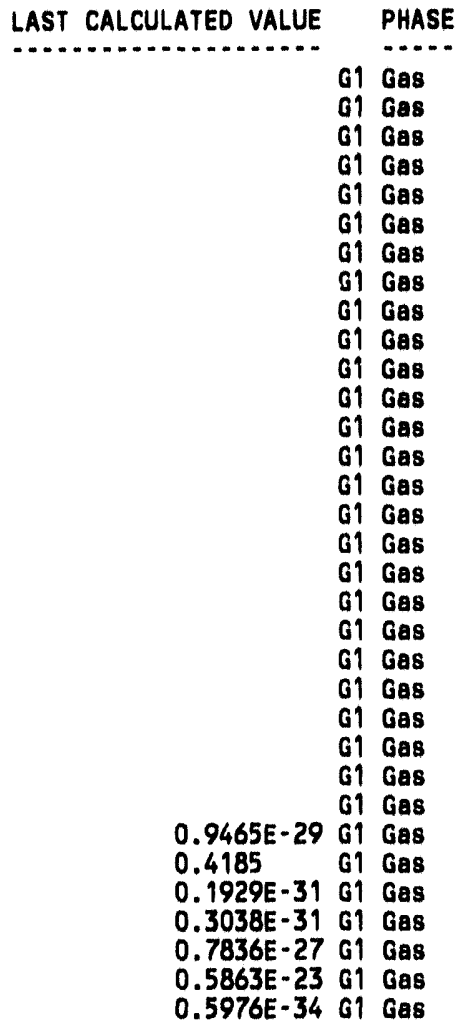

CP RANGE

$298-6000 k$

298 - $3000 \mathrm{~K}$

295 - $300 \mathrm{~K}$

298 - $6000 k$

298 - $1500 \mathrm{~K}$

298 - $6000 k$

298 - $6000 k$

298 - $1500 \mathrm{~K}$

298 - $6000 k$

298 - $6000 k$

$298-4500 \mathrm{~K}$

298 - $4000 \mathrm{~K}$

298 - $6000 k$

298 - $6000 \mathrm{~K}$

298 - $6000 \mathrm{~K}$

298 - $6000 \mathrm{k}$

298 - $2000 \mathrm{~K}$

298 - $2000 K$

298 - $2000 \mathrm{~K}$

298 - $6000 \mathrm{~K}$

298 - $2000 \mathrm{~K}$

298 - $1500 k$

298 - $1200 k$

298 - $298 \mathrm{~K}$

295 - $300 \mathrm{~K}$

298 - $6000 \mathrm{~K}$

298 - $2500 k$

298 - $2500 \mathrm{~K}$

298 - $6000 \mathrm{~K}$

298 - $6000 k$

298 - $6000 \mathrm{~K}$

298 - $2000 \mathrm{~K}$

298 - $6000 \mathrm{~K}$ 


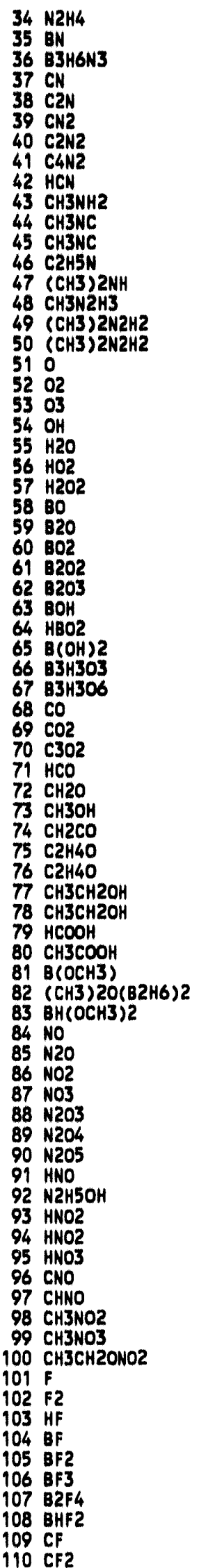

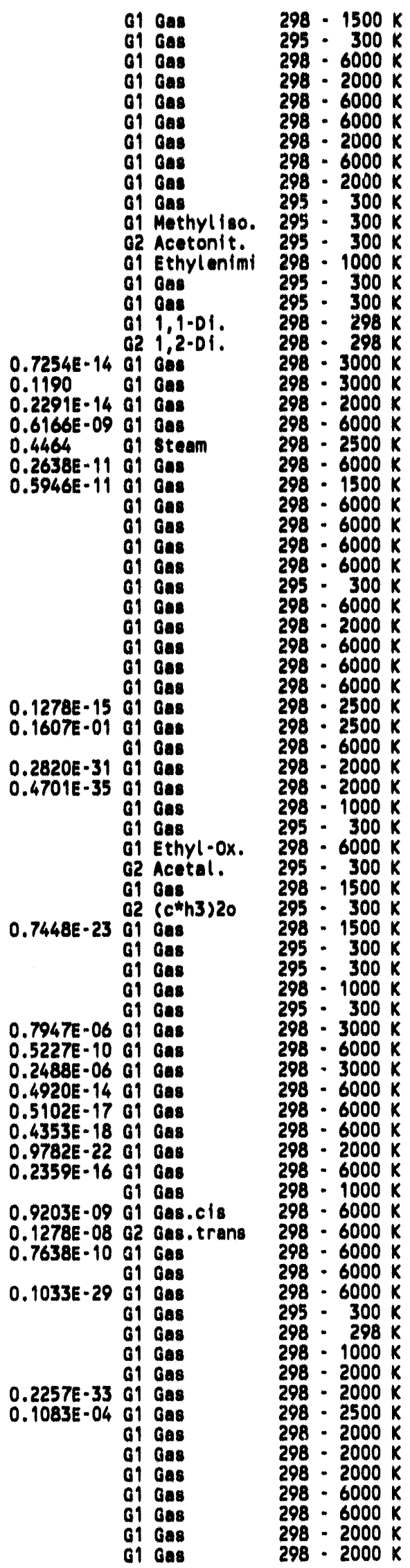


111 C2F2

112 CF 3

113 CF 4

114 C2F 4

$115 \mathrm{C2F}$

$116 \mathrm{CGFG}$

117 C4F8

118 CHF

$119 \mathrm{CH} 3 \mathrm{~F}$

120 C2HF

121 C2FH5

122 CH2F2

123 CH2CF2

124 CH3CHF2

125 CHF3

$126 \mathrm{C2F} 3 \mathrm{H}$

127 CH 3 CF 3

128 NF

129 NF2

130 NF3

131 N2F4

132 CNF

133 C2NF3

134 of

135 O2F

136 F20

137 HOF

$138 \mathrm{BOF}$

139 BOF2

140 B303F

141 B2OF 4

142 B3H2O3F

$143 \mathrm{~B}(\mathrm{OH}) \mathrm{F}$

144 B3HO3F2

$145 \mathrm{COF}$

146 COF2

147 COF 4

148 CHFO

149 ( $\mathrm{CH} 3$ ) 20 (BF3)

150 NOF

151 NO2F

152 NOF3

$153 \mathrm{No}$

$154 \mathrm{Naz}$

$155 \mathrm{NaH}$

$156 \mathrm{NaCN}$

$157 \mathrm{Na2}(\mathrm{CN}) 2$

$158 \mathrm{NaO}$

159 Na2O2H2

$160 \mathrm{NaBO}$

$161 \mathrm{NaF}$

$162 \mathrm{Na2F} 2$

$163 \mathrm{Al}$

$164 \mathrm{Al} 2$

165 AlH

$166 \mathrm{Al}$ (BH4) 3

167 AlC

168 AlO

169 Al02

170 Al20

171 Al202

$172 \mathrm{AlOH}$

$173 \mathrm{AlO} H$

174 AlBO2

175 AlF

176 AlF2

177 AlF3

178 Al2F6

179 AlOF

180 AlOF2

$181 \mathrm{NaAlF} 4$

$182 \mathrm{~S}$

$183 \mathrm{s2}$

18453

$185 \quad 54$

18655

18756
$01 \mathrm{Cas} \quad 298 \cdot 6000 \mathrm{~K}$

01 Gas $298 \cdot 6000 \mathrm{~K}$

$01608 \quad 298 \cdot 6000 k$

$61 \mathrm{Gas} 298 \cdot 6000 \mathrm{~K}$

01 Gas $298 \cdot 6000 K$

Q1 Hexefluoro 298 - $1000 \mathrm{~K}$

01 Octafluoro 298 - $1000 \mathrm{~K}$

61 Ges 298 - $6000 \mathrm{~K}$

01 Cas $208 \cdot 6000 \mathrm{~K}$

01 Cas 298 - $6000 \mathrm{~K}$

01 Fluoroetha $298 \cdot 1000 \mathrm{~K}$

$01 \mathrm{Gas} 298 \cdot 6000 \mathrm{~K}$

$01 \mathrm{Oas} \quad 295 \cdot 300 \mathrm{~K}$

a1 Gas 295 . $300 \mathrm{~K}$

(1) $298 \cdot 6000 \mathrm{~K}$

o1 Prifluoros 298 - $1000 \mathrm{~K}$

$295 \cdot 300 K$

$298 \cdot 6000 K$

a1 Gas $298 \cdot 6000 \mathrm{~K}$

a1 Cas $298 \cdot 6000 \mathrm{~K}$

$01098 \quad 298 \cdot 6000 \mathrm{~K}$

01 oas $298 \cdot 6000 \mathrm{~K}$

$01098.6000 \mathrm{~K}$

$0.10808 \cdot 23$ of cas $\quad 298 \cdot 6000 \mathrm{~K}$

$0.8619 E-21$ o1 oas $298 \cdot 6000 K$

$0.1230 E-35$ o1 G08 $298-2000 K$

$0.1330 E-19$ G GaB $\quad 298 \cdot 6000 \mathrm{~K}$

$01008 \quad 298 \cdot 6000 K$

01 Bas $298 \cdot 6000 \mathrm{~K}$

01 Cas $298 \cdot 6000 \mathrm{~K}$

01 cas $298 \cdot 6000 \mathrm{~K}$

01 Qos $298 \cdot 6000 \mathrm{~K}$

01 one $209 \cdot 6000 \mathrm{~K}$

01 ces $298 \cdot 6000 \mathrm{~K}$

$0.4182 E-3101$ Gas $298 \cdot 2000 K$

$298 \cdot 2000 K$

$298 \cdot 6000 \mathrm{~K}$

$298 \cdot 6000 \mathrm{~K}$

298 - $1000 K$

298 - $1500 \mathrm{~K}$

298 - $6000 \mathrm{~K}$

298 - $6000 k$

298 - $2000 \mathrm{~K}$

$298 \cdot 2000 \mathrm{~K}$

$298 \cdot 2000 k$

298 - $2000 \mathrm{~K}$

298 - $2000 \mathrm{~K}$

$298 \cdot 2200 \mathrm{~K}$

298 - $6000 \mathrm{~K}$

298 - $2000 \mathrm{~K}$

298 - $2500 K$

298 - $2000 K$

2767 - $3200 K$

$295-300 \mathrm{~K}$

298 - $6000 \mathrm{~K}$

298 - $1000 \mathrm{~K}$

$298 \cdot 6000 \mathrm{~K}$

298 - $2000 \mathrm{~K}$

298 - $2000 \mathrm{~K}$

$298 \cdot 6000 \mathrm{~K}$

298 - $2000 \mathrm{~K}$

209 - $6000 \mathrm{~K}$

$298 \cdot 6000 \mathrm{~K}$

298 - $6000 \mathrm{~K}$

298 - $2000 K$

298 - $2000 \mathrm{~K}$

298 - $2000 \mathrm{~K}$

298 - $6000 \mathrm{~K}$

298 - $2500 \mathrm{~K}$

298 - $6000 \mathrm{~K}$

$298 \cdot 6000 K$

298 - $2000 K$

298 - $2000 \mathrm{~K}$

298 - $2000 \mathrm{~K}$

298 - $2000 k$

298 - $2000 \mathrm{~K}$

298 - $2000 k$ 


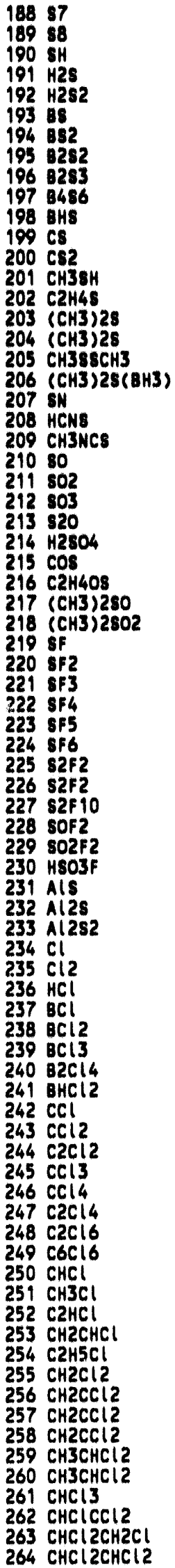

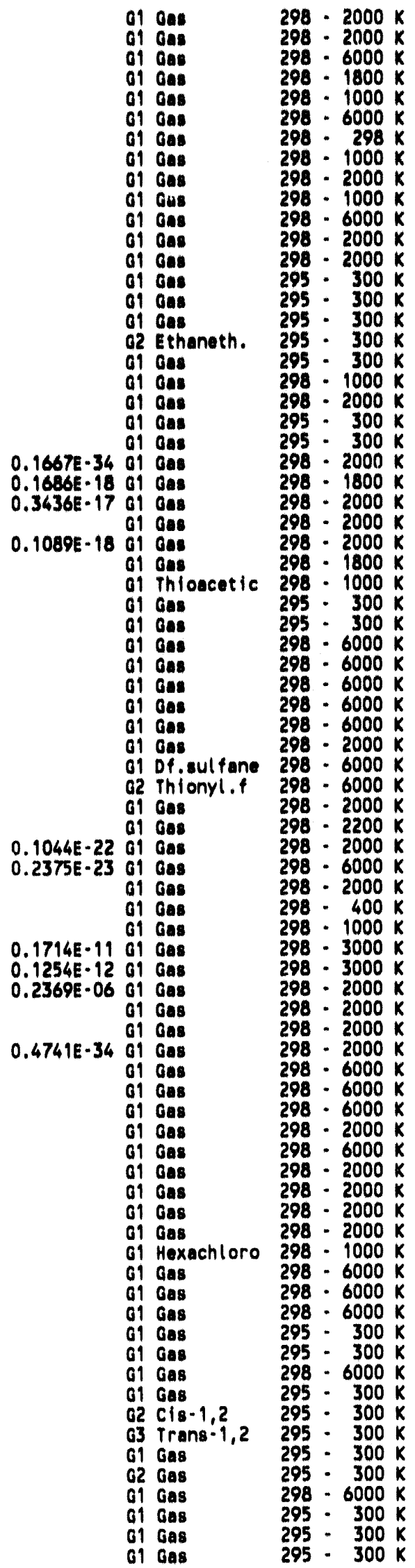




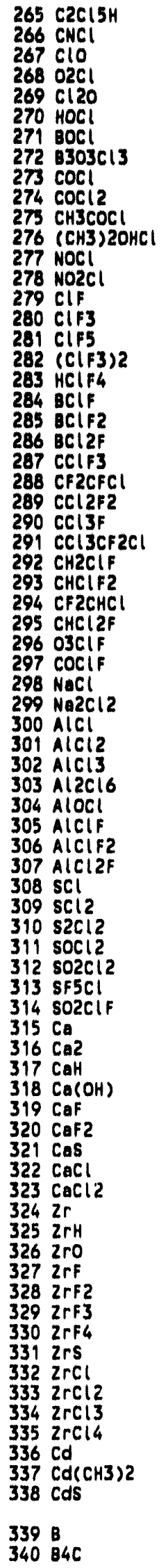

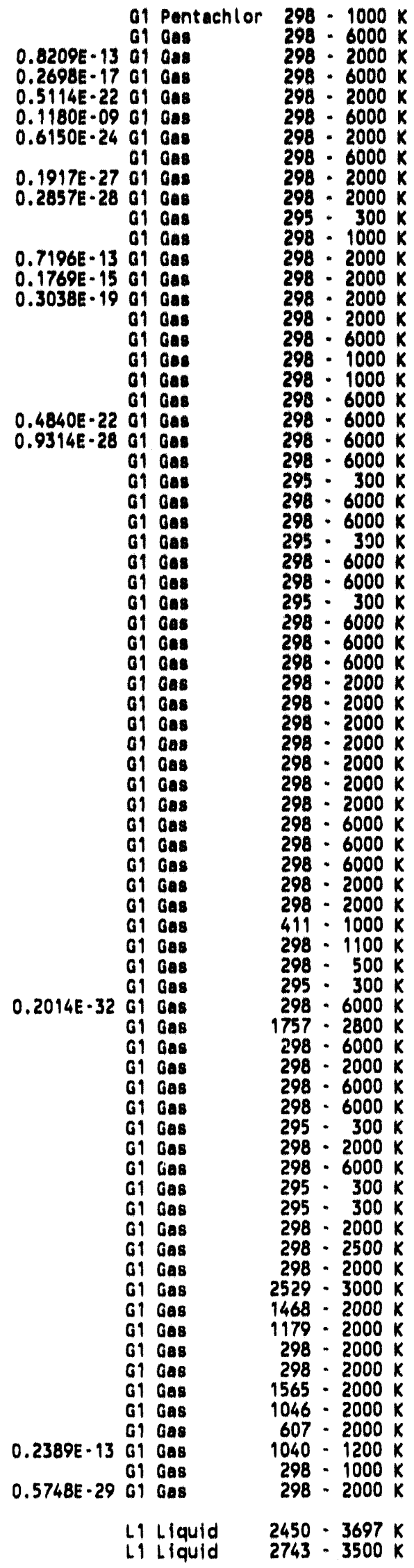


341 N2H4

342 HN3

343 B3H6N3

344 HCN

345 CH3NH2

346 CH3NC

347 CH3NC

348 (CH3)2NH

349 CH3N2H3

350 (CH3)2N2H2

351 (CH3) ZN2H2

$352 \mathrm{H2O2}$

353 -203

354 CH3OH

$355 \mathrm{C2H} 4 \mathrm{O}$

$3.56 \mathrm{C} 2 \mathrm{H} 4 \mathrm{O}$

357 CH3CH2OH

$358 \mathrm{HCOOH}$

$359 \mathrm{CH} 3 \mathrm{COOH}$

360 (CH2OH) 2

361 вH(OCH3)2

$362 \mathrm{~N}_{24}$

$363 \mathrm{NH4OH}$

364 (NHG) 20

365 HNO3

$366 \mathrm{CH} 3 \mathrm{NO2}$

367 CH3NO3

368 CH3CH2ONO2

$369 \mathrm{Na}$

370 C2Na2

371 NaCN

$372 \mathrm{NazO}$

$37 \mathrm{NaOH}$

$374 \mathrm{NaBO} 2$

373 (Na2O)(B203)2

$376 \mathrm{Na2CO}$

377 NaNO2

378 NaNO3

379 NaF

380 Al

381 Al( (BH4) 3

382 Al203

383 Na3AlF 6

3848

385 H282

$386 \mathrm{B283}$

387 Cs2

$388 \mathrm{CH} 38 \mathrm{H}$

389 C2H48

390 (CH3) 28

391 (CH3) 25

$392 \mathrm{CH}_{385 \mathrm{CH}} 3$

393 H2Cs3

394 (CH3)2S(BH3)

$395 \mathrm{SO3}$

$396 \mathrm{H28O4}$

$397 \mathrm{H}^{2 \mathrm{SO}} 4$ (H2O)

$398 \mathrm{H}^{2} \mathrm{SO} 4(\mathrm{H} 2 \mathrm{O}) 2$

$399 \mathrm{H}_{2} \mathrm{SO} 4(\mathrm{H} 2 \mathrm{O}) 3$

$400 \mathrm{H}^{2} \mathrm{SO} 4(\mathrm{H} 2 \mathrm{O})$

401 (H2SO4)2(H2O) 13

402 (CH3) 280

$4035 F 6$

$404 \$ 2 F 10$

$405 \mathrm{NaS}$

$406 \mathrm{Na2s}$

407 Nas2

$408 \mathrm{Na2s3}$

$409 \mathrm{Na2s03}$

$410 \mathrm{Na}_{4} \mathrm{SO}_{4}$

411 Al2s3

$412 \mathrm{BCl} 3$

$413 \mathrm{B2Cl} 14$

$414 \mathrm{CCl} 14$

$415 \mathrm{C2Cl} 4$

$416 \mathrm{C2H5Cl}$

$417 \mathrm{CH} 2 \mathrm{Cl} 2$
L1 llquid

LI Llquid

tI Llquid

II Llquid

it Llauld

i. Mothyliso.

12 Acetonit.

II Llquid

II Llquid

(1) $1,1.01$.

(2) $1,2.01$

11 liquid

11 Amorphous

II Llquid

il Ethyl-Ox.

12 Acetol.

L1 Llquid

LI Llquid

LI Liquid

il Liquid

li liquid

LI hiquid

LI Liquid

li liquid

li hiquld

li Liquid

li liquid

(1 Llquid

$0.3162 E-16$ LI Liquid

L1 Liquid

LI Liquid

LI liquid

t1 liquid

li liquid

II liquid

LI Liquid

ll hiquid

l1 liquid

il Llquid

11 hiquid

LI Llquid

L1 Liquid

li hlquid

L1 Liquid

Il liquid

L1 Liquid

L1 Liquid

L1 Liquid

L1 Liquid

LI Liquid

L2 Ethaneth.

LI Liquid

L1 Liquid

(1 Liquid

L1 Liquid

LI Liquid

il Liquid

L1 Liquid

LI liquid

L1 Iiquid

L1 Liquid

LI Liquid

L1 Liquid

LI Liquid

L1 Liquid

L1 Liquid

LI Liquid

LI Liquid

il Liquida

LI Liquid

LI Liquid

L1 Liquid

L1 Liquid

LI Liquid

L1 Liquid

LI Liquid

L1 liquid
295 - $300 \mathrm{~K}$

298 - $298 K$

298 - $310 k$

295 - $300 k$

298 - $310 k$

298 - $310 \mathrm{~K}$

295 - $300 k$

295 - $300 k$

295 - $300 \mathrm{~K}$

295 - $300 K$

295 - $300 K$

298 - $431 \mathrm{~K}$

298 - $2316 k$

298 - $338 K$

295 - $300 K$

298 - $310 k$

298 - $352 k$

298 - $374 K$

295 - $300 K$

293 - $300 k$

298 - $310 K$

293 - $300 k$

295 - $300 k$

295 - $300 k$

295 - $300 k$

295 - $300 K$

295 - $300 \mathrm{~K}$

295 - $300 \mathrm{~K}$

371 - $1156 k$

546 - $1100 k$

$835 \cdot 1803 K$

$1405 \cdot 2223 k$

593 - $1663 \mathrm{~K}$

$1239 \cdot 2000 k$

1016 - $2000 k$

$1123 \cdot 2000 k$

557 - $800 K$

$379 \cdot 700 k$

$1269 \cdot 1983 k$

933 - $2767 k$

295 - $300 k$

2327 - $3500 \mathrm{~K}$

$1285 \cdot 2500 K$

388 - $718 \mathrm{~K}$

240 - $313 K$

$836 \cdot 1100 K$

298 - $319 K$

295 - $300 k$

298 - $310 k$

295 - $300 k$

295 - $300 k$

295 - $300 k$

298 - $331 K$

298 - $310 k$

298 - $310 K$

298 - $553 k$

295 - $300 k$

295 - $300 k$

295 - $300 k$

295 - $300 \mathrm{~K}$

295 - $300 k$

295 - $300 k$

298 - $310 \mathrm{~K}$

298 - $298 K$

$753 \cdot 1500 k$

$1251 \cdot 2200 k$

458 - $1000 k$

$126 \cdot 1000 \mathrm{~K}$

1000 - $2000 k$

$1157 \cdot 2000 k$

1370 - $1800 K$

295 - $300 k$

295 * $300 k$

298 - $350 \mathrm{~K}$

295 - $300 k$

295 - $300 \mathrm{~K}$

295 - $300 \mathrm{~K}$ 
418 CH2CCI2

410 CH2CCI

420 CH2CCl2

421 CH3CHCl2

422 CH3CHCI2

$423 \mathrm{CHCl}_{3}$

$426 \mathrm{CHClCCl}$

425 CHCIZCH2Cl

$426 \mathrm{CHCl} 2 \mathrm{CHCl}$

$427 \mathrm{CH} 3 \mathrm{COCl}$

$428 \mathrm{CCl3F}$

$429 \mathrm{NaCl}$

$430 \mathrm{s2Cl}$

$431 \mathrm{Co}$

432 CoO

433 (C.0)(B203)

434 (C.O) (B203)?

$435(C .0) 2(1203)$

436 (ca) 3(1.203)

437 Ceft

$438 \mathrm{canl} 2$

439 caAl

440 cacle

$4412 \mathrm{r}$

$4422 \mathrm{rm2}$

$443 \mathrm{ZrN}$

$4642 \mathrm{roz}$

$4452 r f 2$

$4462 \mathrm{rcl} 2$

$447 \mathrm{~cd}$

$446 \mathrm{Cd}(\mathrm{CH} 3) 2$

449 Nacd2

$450 \mathrm{CoCl} 2$

4511120

6418

642810 H14

$643 \mathrm{C}$

$644 \mathrm{C}$

645 S4C

646 NM4MI

647 BN

648 CNH(NH2) (NHCN)

649 H2O

6308203

$651 \mathrm{HBO}$

$652 \mathrm{HBO} 2$

$653 \mathrm{HBO2}$

654 H3103

$655 \mathrm{N2O}$

656 NHANO3

657 CO(NH2)2

658 NH2CH2COOH

659 NH2COONH4

660 NHAHCO3

661 NH4F

662 NHSF 2

$663 \mathrm{Na}$

$664 \mathrm{NaH}$

$665 \mathrm{C}^{\mathrm{Na} 2}$

$666 \mathrm{NaCN}$

$667 \mathrm{NoO}$

$668 \mathrm{Na2O}$

$669 \mathrm{Na2O}$

$670 \mathrm{NazO}$

$671 \mathrm{NazO2}$

$672 \mathrm{Na202}$

$673 \mathrm{NaOH}$

$674 \mathrm{NaOH}$

$675 \mathrm{NaBO} 2$

676 (Na2O)(B203)2

677 (No2O)(B203)3

$678 \mathrm{Na2CO}$

$679 \mathrm{Na2CO3}$

$680 \mathrm{NaHCO}$

681 NaNO2

682 NaNO2

11 Lquid

$293.300 k$

li llauid

hl Lould 295 - $300 \mathrm{~K}$

Il llquid 295 . $300 k$

1 llquid 298 . $298 k$

II Llquid 295. $300 k$

Il Llquid $295 \cdot 300 \mathrm{~K}$

Ll Liquid 295 . $300 \mathrm{~K}$

II Hould 1074 - 1785 $\mathrm{k}$

LI hlquld 298 . $411 \mathrm{~K}$

LI Llquid 1112 - $1737 \mathrm{~K}$

Ll llquld $2888 \cdot 3500 k$

Ll llquid 1433 - $2000 \mathrm{~K}$

il llquid 1263. $2000 \mathrm{~K}$

Ll llquid $1503 \cdot 2000 k$

1 llquid $1763 \cdot 2000 \mathrm{~K}$

il liquid $1691.1800 \mathrm{~K}$

4 llquid 1353 * $1000 \mathrm{~K}$

li llauld $1050 \cdot 1700 \mathrm{~K}$

il liquid $1045 \cdot 2273 k$

Ll Llouid $2125 \cdot 6777 k$

11 llquid 3323 - $4666 \mathrm{~K}$

il liquild 3225 - $3500 \mathrm{~K}$

4 Llquid $2950 \cdot 4368 \mathrm{~K}$

11 llquid $1175 \cdot 2529 \mathrm{~K}$

li liquild $1000 \cdot 1565 \mathrm{~K}$

$0.1232 E \cdot 11$ LI liquid $\quad 394 \cdot 1040 \mathrm{~K}$

ll llquld $295 \cdot 300 \mathrm{~K}$

ll llquid 655 : $900 \mathrm{~K}$

il Llquid 273 : $374 k$

81 solld

81 solla

$0.23135-2781$ oraphlte

82 Dlemond

il solla

si solla

$0.64345 \cdot 2781$ solla

81 solla

81 ice

81 solla

81 solla

82 Monoclínic

33 orthorhom.

81 solld

81 solla

81 solla

si solla

$s 1$ solid

81 solla

si solla

81 solla

$s i$ solla

si solla

si solla

81 solla

si solla

81 solla

$0.4422 E-12$ si solid-c

82 Solld-B

83 solld.A

$0.2498 E \cdot 10 \mathrm{si}$ solid.A

82 solld-B

si solld-a

82 solid-a

0.1117

8180110

0.1006 - 07 si solld

81 solía

81 solid-A

0.6273

82 solla-B

81 solld

81 Alph.

s2 sete

$298 \cdot 2450 k$

295 - $300 \mathrm{~K}$

298 - $4073 k$

298 - $1200 \mathrm{~K}$

290 - $2743 x$

298 - $299 k$

298 - $1200 \mathrm{~K}$

295 - $300 k$

$250 \cdot 273 k$

298 - $723 k$

298 - $509 k$

298 - $310 \mathrm{~K}$

298 - $310 k$

298. $444 k$

295 - $300 \mathrm{~K}$

295 . $300 k$

295 - $300 \mathrm{~K}$

295 - $300 \mathrm{~K}$

298 . $298 \mathrm{~K}$

298 - $310 \mathrm{~K}$

205. $300 \mathrm{~K}$

295 - $300 k$

298 - $371 \mathrm{~K}$

298 - $700 k$

298 - $546 k$

298 - $835 \mathrm{~K}$

298 - $825 k$

298 - $1023 k$

1023 - $1243 k$

1243 - $1405 k$

298 - $785 k$

785 - $948 K$

298 - $368 k$

368 - $393 k$

298 - $1239 K$

298 - $1016 k$

298 - $1030 k$

298 - $723 k$

723 - $1123 k$

298 - $500 k$

298 - $434 K$

434 - $557 k$ 


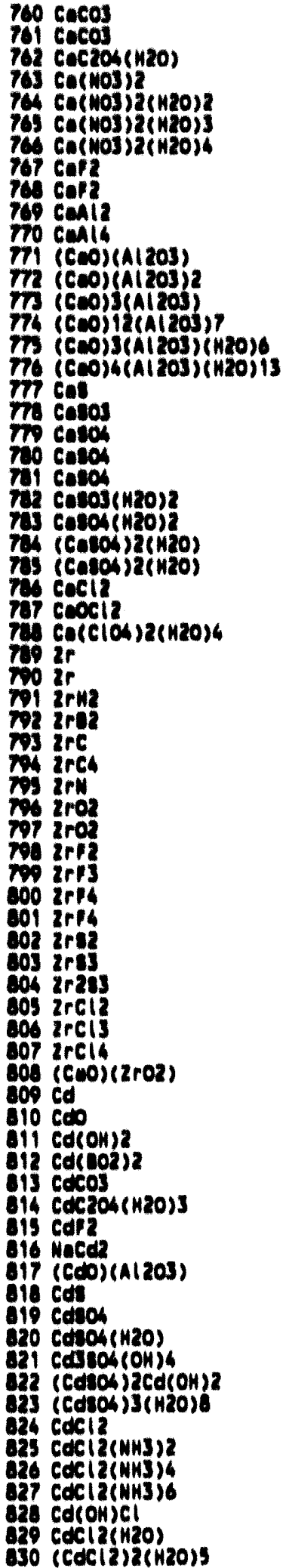

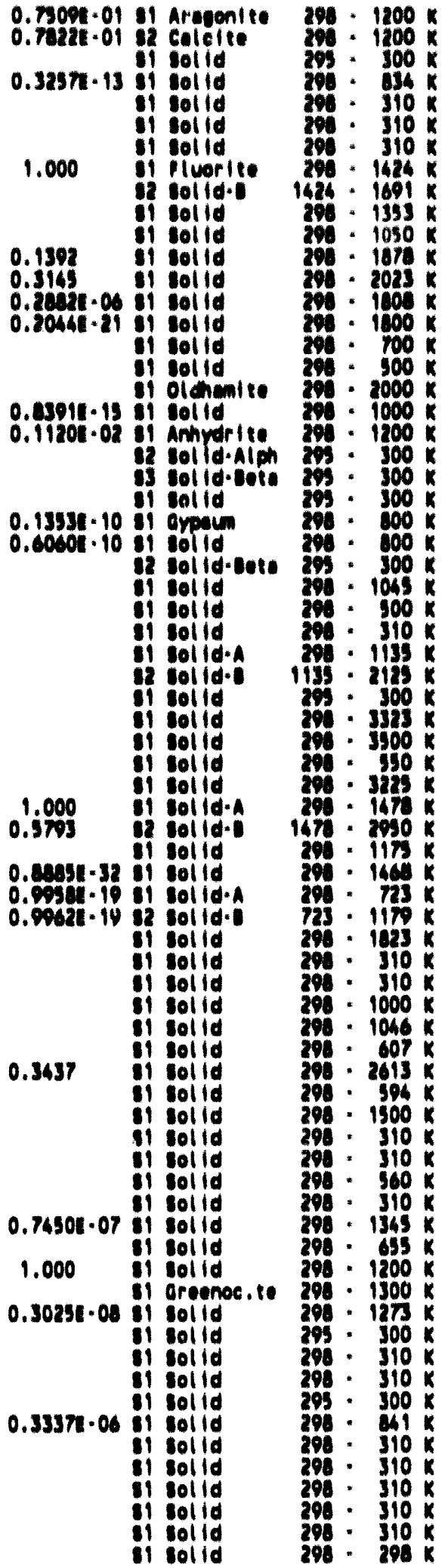

LIST, (HLLP ALL O LIO AO 8 BOLN PRIV 2.11 LOC) enten list comuno (n POn HELP) on phese artitunns to continue

$111 \cdot 23,26 \cdot 34,36 \cdot 42,46,51 \cdot 37,68 \cdot 73,75,77,79,82,94 \cdot 97,102,103,109 \cdot 122$, 
continue the oflection

$126 \cdot 137,145 \cdot 162,102 \cdot 192,207,210 \cdot 216,210 \cdot 210,234 \cdot 252,261,265 \cdot 274$,

continue the stiction

$276 \cdot 267,306 \cdot 311,314,331,332,334,336 \cdot 330 / 369,344,467 / 641,043,047,666,640$,

continue the setection

$671,675,676,670,64,645,697 \times 691,696,697,700,702,704,710,718,723,725$,

continut int steterion

$720,720,730,730,749,747,790,731,732,734 \cdot 761,763,707,769 \cdot 77,777 \cdot 790$,

continut int stitcrion

$73,74,700,702,703,705 \cdot 802,005,806,000,015,017 \cdot 019,024$

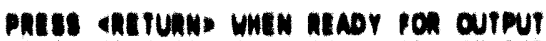

On Inten options(s), on enten non fan optlons minu

(enter IC to so to cominand mode)

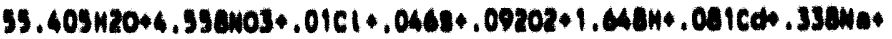

$1.7091+1.05560+.160+.303 A 1+.2332 r *$

$13.102+52.4 M 2+2.16 \cdot 4.2 \mathrm{n}=$

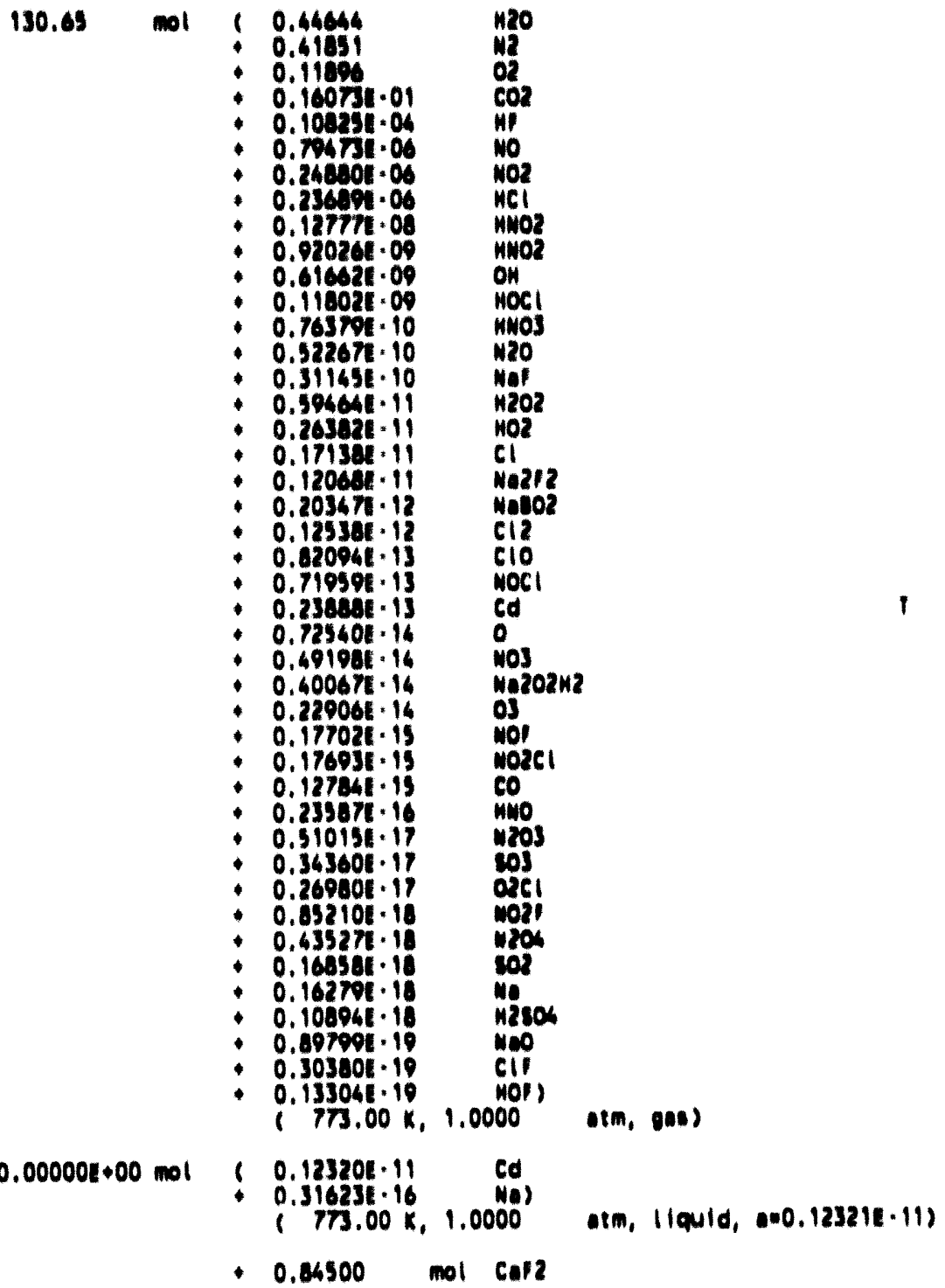




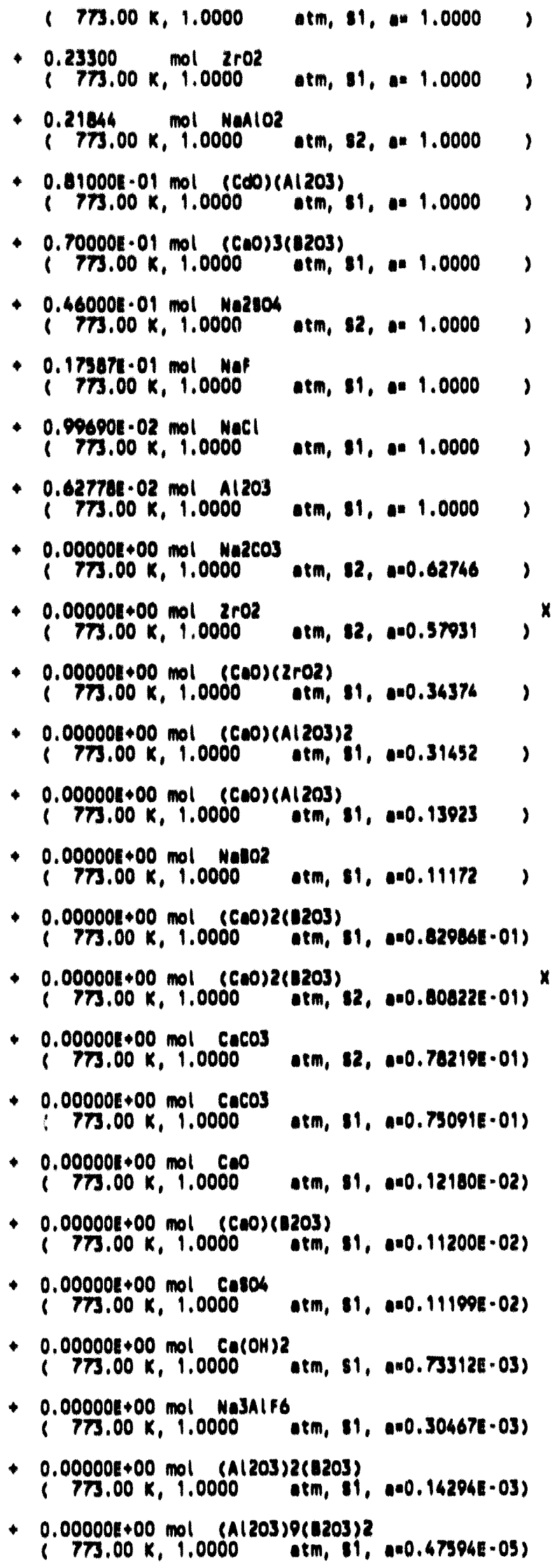


$+0.00000 \mathrm{E}+00 \mathrm{~mol} \mathrm{CdCl} 2$

( $773.00 \mathrm{~K}, 1.0000$ atm, 81, $=0.33374 \mathrm{E}-06$ )

$+0.00000 \mathrm{E}+00 \mathrm{~mol}$ (CaO)3(Al 203)

( $773.00 \mathrm{~K}, 1.0000$ atm, $81,=0.28816 \mathrm{E}-06)$

$+0.00000 \mathrm{E}+00 \mathrm{~mol}$ CdF2

$(773.00 \mathrm{~K}, 1.0000$ atm, s1, $=0.744998-07)$

$+0.00000 \mathrm{E}+00 \mathrm{~mol}$ (Na20)(B203)2

( $773.00 \mathrm{~K}, 1.0000$ atm, $81, a=0.10063 E-07)$

$+0.00000 \mathrm{E}+00 \mathrm{~mol} \mathrm{cds} 04$

( $773.00 \mathrm{x}, 1.0000$ otm, s1, =0.30248E:08)

$+0.00000 \mathrm{E}+00 \mathrm{~mol}(\mathrm{CaO})(\mathrm{B203}) \mathrm{2}$

$(773.00 \mathrm{~K}, 1.0000 \quad \Delta t \mathrm{~m}, 81,0=0.36264 E \cdot 09)$

$+0.00000 \mathrm{E}+00 \mathrm{~mol} \quad \mathrm{All} 3$

( $773.00 \mathrm{~K}, 1.0000$ atm, s2, =0.147018.09)

$+0.00000 \mathrm{E}+00 \mathrm{~mol}$ (CasO4)2(H2O)

$(773.00 \mathrm{~K}, 1.0000 \mathrm{~atm}, 81,=0.609996 \cdot 10)$

- $0.00000 \mathrm{E}+00 \mathrm{~mol}$ Maz202

( $773.00 \mathrm{~K}, 1.0000$ atm, 81, an0.24979E-10)

$+0.00000 \mathrm{E}+00 \mathrm{~mol}$ Caso4(H2O)2

( $773.00 \mathrm{k}, 1.0000$ atm, $81,0=0.135358-10)$

$+0.00000 E+00 \mathrm{~mol} \mathrm{Ma2O}$

(773.00 K, 1.0000 otm, $11,0=0.44225 E-12$ )

$+0.00000 E+00 \mathrm{~mol} \operatorname{Co}(\mathrm{NOS}) 2$

( $773.00 \mathrm{~K}, 1.0000$ otm, $1,0.0 .32570 \mathrm{E} \cdot 13$ )

$+0.00000 \mathrm{E}+00 \mathrm{~mol} \mathrm{MazsOS}$

$(773.00 \mathrm{~K}, 1.0000$ atm, $1,0=0.10252 \mathrm{E} \cdot 14)$

$+0.000008+00 \mathrm{~mol} \mathrm{cas03}$

( $773.00 \mathrm{~K}, 1.0000$

$\Delta t m, s 1,=0.03912 E-15)$

$+0.00000 \mathrm{E}+00 \mathrm{~mol} \mathrm{2rP4}$

( $773.00 \mathrm{~K}, 1.0000$

atm, s2, ano.09620E-19s

$+0.00000 \mathrm{E}+00 \mathrm{~mol} 2+\% 4$

( $773.00 \times, 1.0000$

atm, s1, a-0.09576E-19)

The cutoff concentration has been specifled to $1.000 E-20$

Dote on 3 product spectes ldentllled with "x" have not been extrapolated in comput ing the phase asiemblage

Dete on 1 product upecien Identifled with "f" have been extrapolated

Press ecns or enter $C$ for chemical capacitance table or enter halp 
1. J. R. Berreth, Inventories and properties of ICPP Calcined High-Level Waste, WINCO-1050, February, 1988, p. iv.

2. Pure and Applied Chemistry, 30, 637 (1972).

3. G. F. Kessinger, Verification of Thermodynamic Codes REACT and EQUILIB for the study of Non-aqueous Inorganic systems, WINCO1105, September, 1992 .

4. Ihsan Barin in collaboration with F. Sauert, E. Schultze-Rhonhof, and W. S. Sheing, Thermochemical Data of pure substances, VCH Publishers, New York, 1989. 

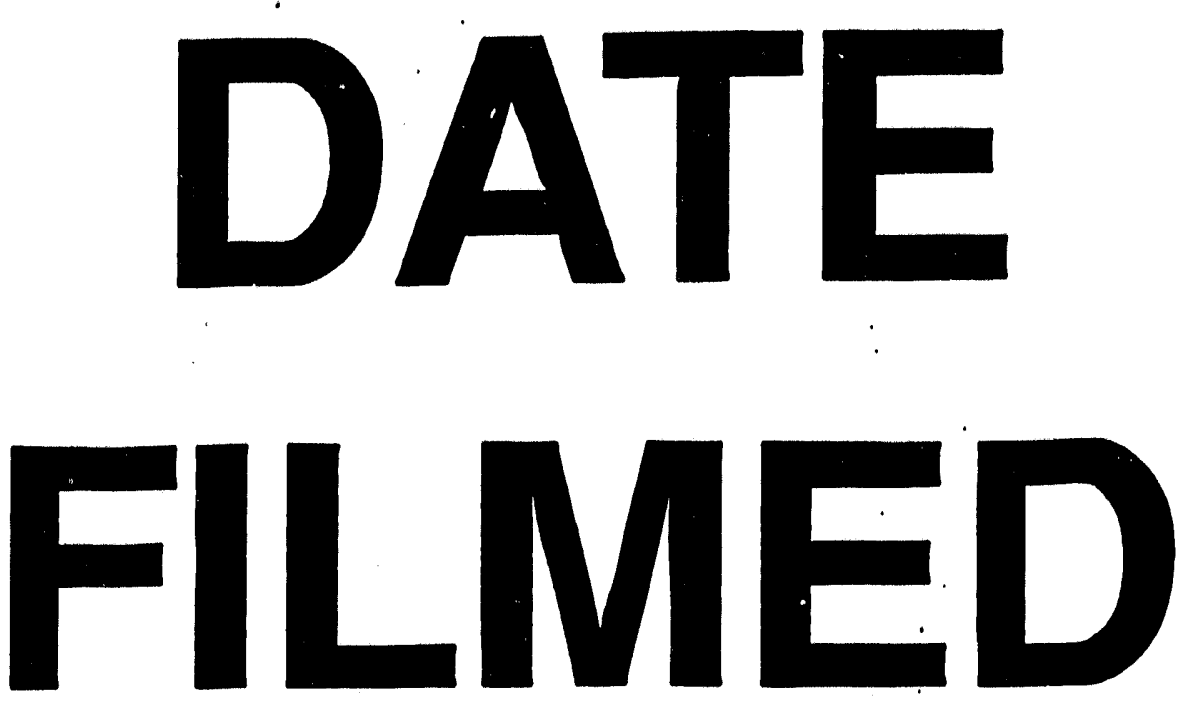

111
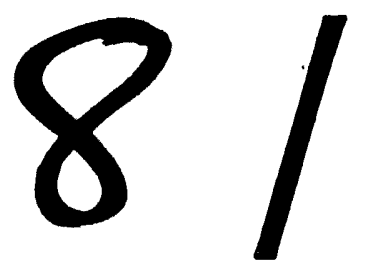

93
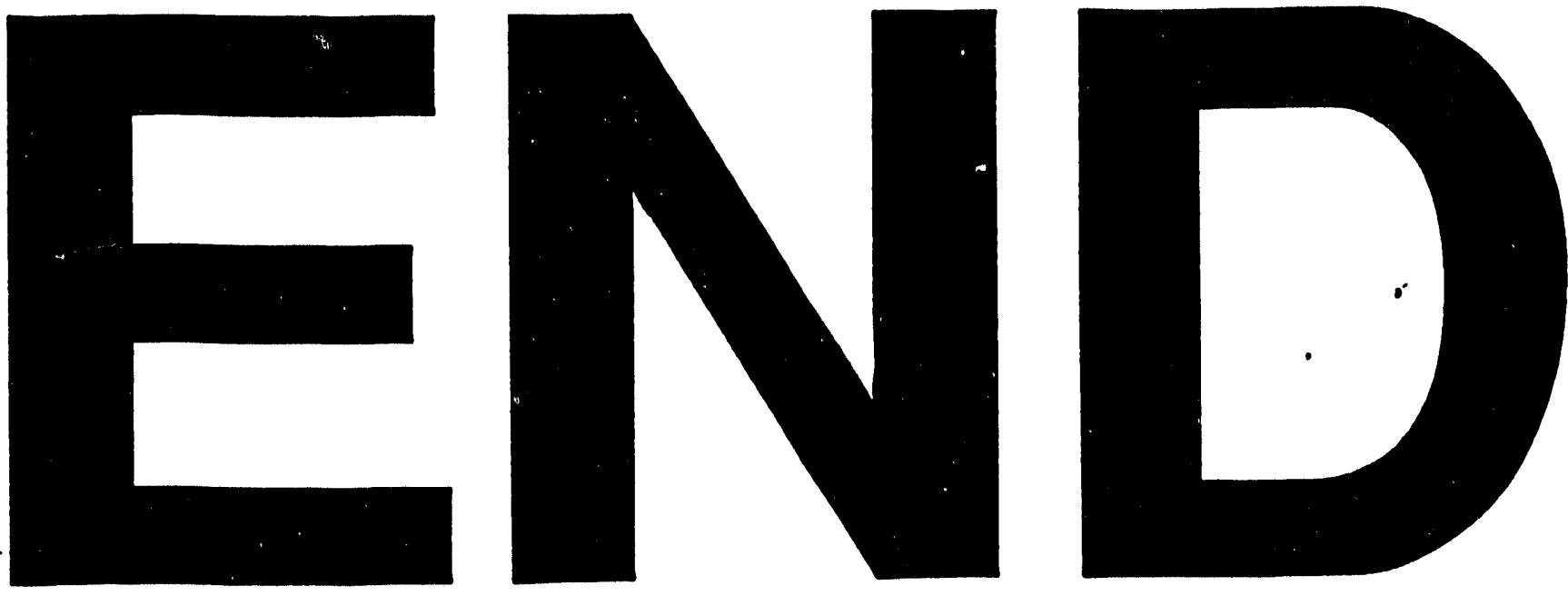


$$
-
$$

(1) 